Chinese Farmers' Cooperatives and Smallholder Farmers

\author{
Jinghui Hao
}




\section{Thesis committee}

\section{Promotor}

Prof. Dr W.J.M. Heijman

Professor of Regional Economics

Wageningen University \& Research

\section{Co-promotors}

Dr N.B.M. Heerink

Associate professor, Development Economics Group

Wageningen University \& Research

Dr W.J.J. Bijman

Associate professor, Management Studies Group

Wageningen University \& Research

\section{Other members}

Prof. Dr J.C.M. van Trijp, Wageningen University \& Research

Dr G. Beekman, Wageningen University \& Research

Prof. Dr X. Xia, Northwest A\&F University, Yangling, China

Prof. Dr S. Feng,Nanjing Agricultural University, Nanjing, China

This research was conducted under the auspices of Wageningen School of Social Science (WASS). 


\title{
Chinese Farmers' Cooperatives and Smallholder Farmers
}

\author{
Jinghui Hao
}

\section{Thesis}

submitted in fulfilment of the requirements for the degree of doctor at Wageningen University and Research by the authority of the Rector Magnificus,

Prof. Dr A.P.J. Mol, in the presence of the

Thesis Committee appointed by the Academic Board to be defended in public on Monday 2 July 2018 at 4 p.m. in the Aula. 
Jinghui Hao

Chinese Farmers' Cooperatives and Smallholder Farmers 145 pages.

$\mathrm{PhD}$ thesis, Wageningen University and Research, Wageningen, NL(2018) With references, with summaries in English

ISBN: 978-94-6343-785-1

DOI: https://doi.org/10.18174/451420 


\section{Table of contents}

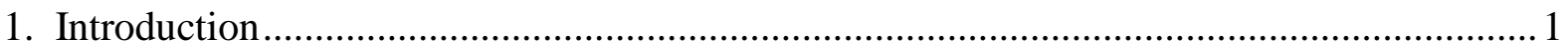

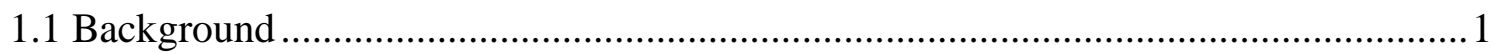

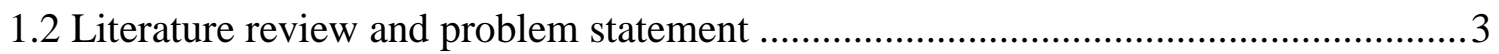

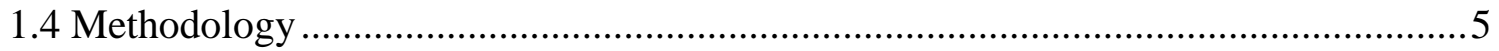

2. Development and Characteristics of Farmers' Cooperatives in China: A Review and

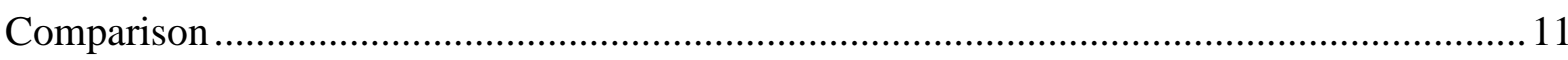

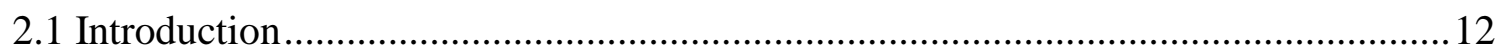

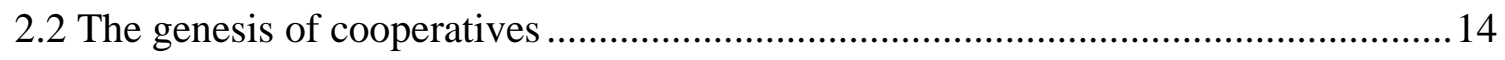

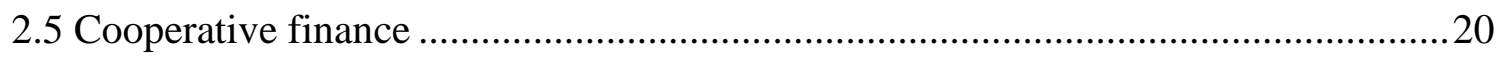

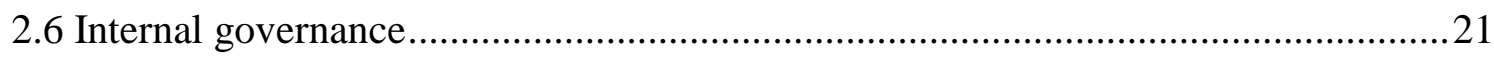

2.7 Relationships between cooperatives and the government ..................................23

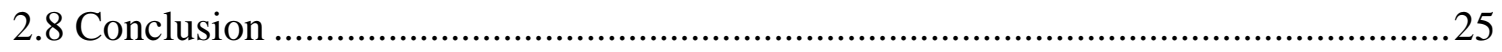

3. Cooperative membership and farmers' choice of marketing channels: Evidence from apple farmers in Shaanxi and Shandong Provinces, China................................................. 31

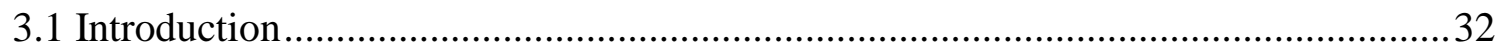

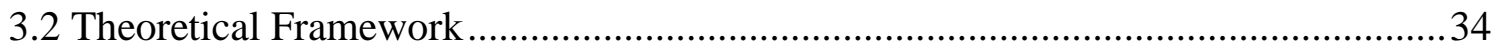

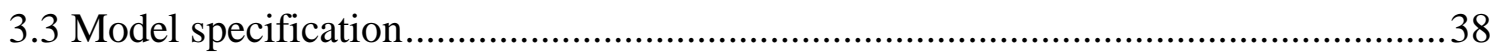

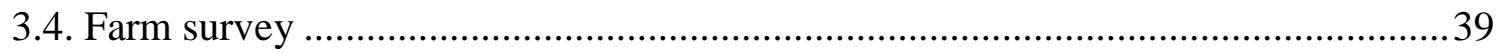

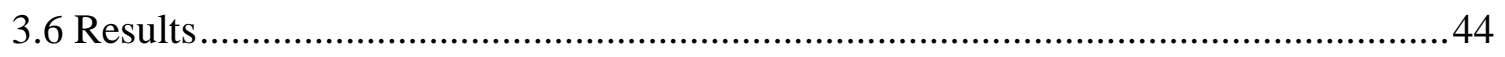

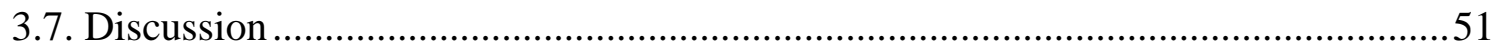

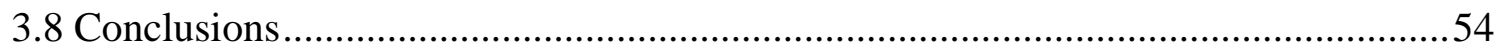

4. Cooperative Membership and Smallholder s' Yields and Profits- Evidence from apple

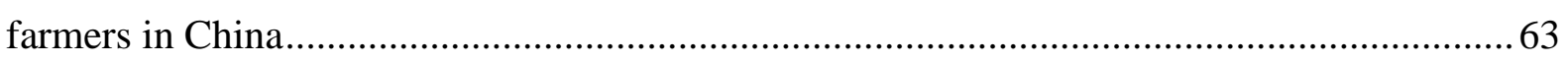

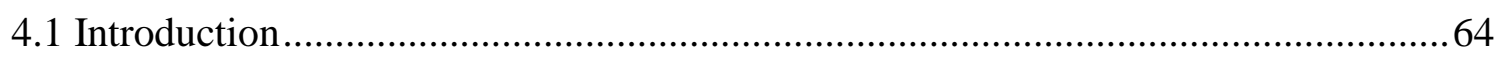


4.2 Conceptual framework

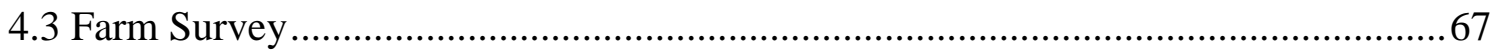

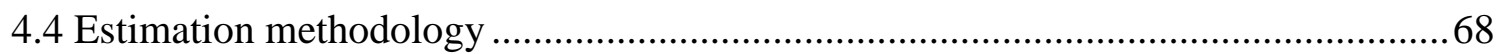

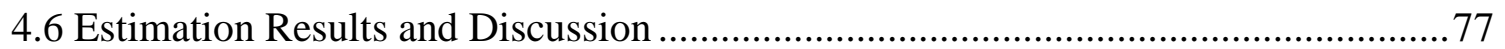

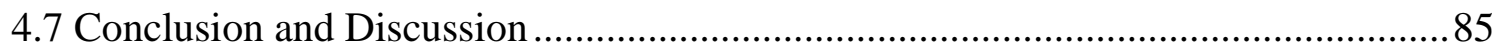

5. Cooperative member commitment, trust and social pressure: The role of members'

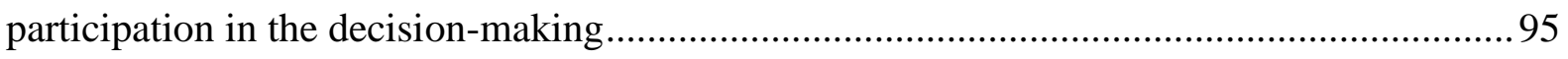

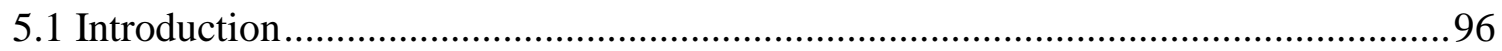

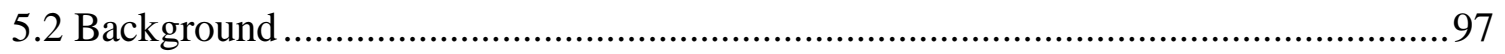

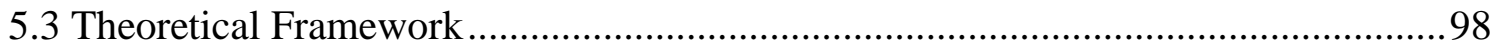

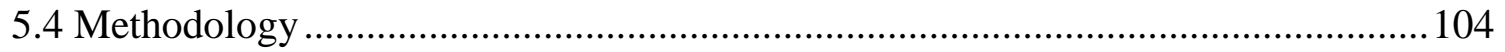

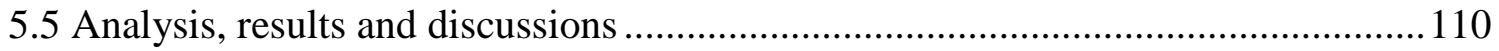

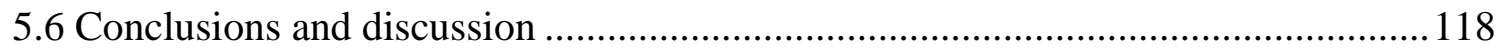

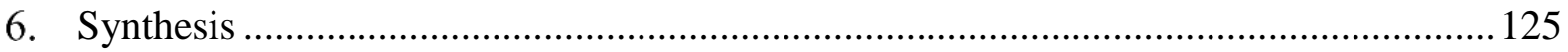

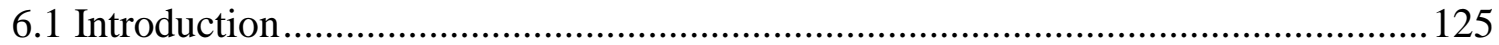

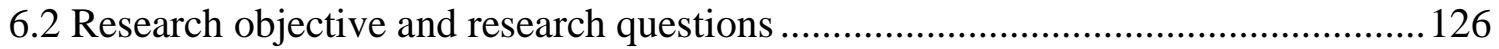

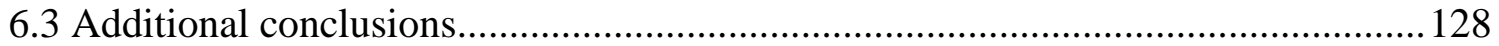

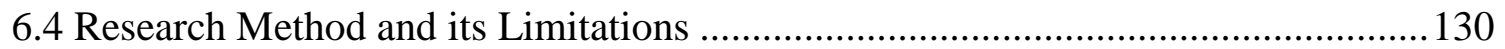

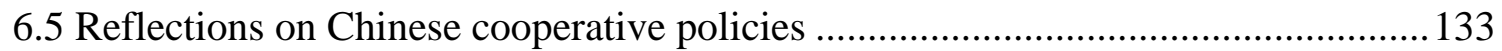

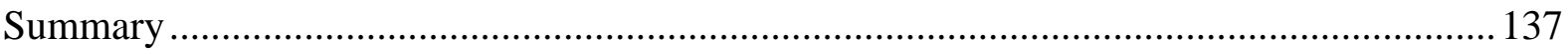


TO MY FAMILIES 



\section{Introduction}

\subsection{Background}

Smallholder farmers are confronted with many challenges when adapting to new food markets. These challenges are mainly associated with the disadvantageous status of smallholder farmers in markets. The first constraint comes from the small scale of transactions. Buyers prefer transactions which save their time of sourcing and collecting information for a given quality of raw materials. They thus prefer a small number of largescale suppliers over a large number of small-scale producers (Sauer et al., 2012). Another constraint experienced by smallholder farmers is asymmetric information. Lacking appropriate market information makes it difficult for farmers to comply with the quality and other requirements and puts them in a weak bargaining position vis-a-vis other parties in the value chain.

A cooperative is considered to be an institutional vehicle that can help farmers to deal with the above described challenges. Cooperatives can improve farmers' bargaining power in both input and output markets (Fischer and Qaim, 2012) and facilitate information flows between farmers and the market (Mojo et al., 2017). In addition, compared with bilateral contracts or other types of market institutions, a cooperative is generally more inclusive of smallholders (Verhofstadt and Maertens, 2014). By strengthening the market position of smallholder farmers, cooperatives can contribute to alleviating poverty and rural development (Bernard and Spielman, 2009).

The potential role of cooperatives is particularly relevant for China, as Chinese agriculture is facing two important challenges. The first challenge refers to how to further develop modern agriculture given the condition of land fragmentation and the existence of a very large number of smallholder farmers. The other challenge is about how Chinese smallholder farmers can cope with the structural changes in agro-food markets and obtain benefits in the changing market environment.

Since the implementation of the Reform and Opening Up policy in 1978, China has obtained great societal and economic achievements. However, the development of agriculture tends to 
lag behind the industrialization and urbanization. The creation and adoption of the Household Responsibility System (HRS) in the early 1980s has made the farm household the basic unit of agricultural production. On the one hand, the HRS provided most farm households with an adequate base for achieving sustainable livelihoods. On the other hand, it resulted in a high degree of land fragmentation and the existence of millions of smallholder farms, which has become an important obstacle to the development of modern agriculture and to further growth in farm incomes (Tan et al., 2006).

Due to the increasing purchasing power of consumers, technical developments in controlling food safety, and especially the recent food scandals, demand for food with better quality and stricter safety standards is growing within China (Narrod et al., 2009). Furthermore, with the rise of supermarkets and international trade, especially the increasing share of high quality food in international trade (Tran et al., 2013), consumption patterns have been evolving. Therefore, agro-food markets are experiencing major structural changes.

These changes can be both opportunities and challenges for smallholders in China. They allow farmers to benefit from new market opportunities arising from export markets, local supermarkets and new processing firms (Bijman, 2016). However, they also call for products of high and consistent quality, which requires farmers to comply with both stricter production and safety standards and a better coordination of sequential activities in the value chain (Fritz and Schiefer, 2008; Reardon et al., 2009; Abebe et al., 2013).

The Chinese government has been promoting the development of cooperatives to meet the new demands in food markets since the 2000s (Jia et al., 2012) and to link smallholder farmers to modern markets. The promulgation of the Law of the People's Republic of China on Farmers' Specialized Cooperatives in 2007 is considered to be a milestone for the development of Chinese cooperatives. As of September 2017, over 100 million farmer households are participating in at least one cooperative, accounting for $47 \%$ of the total number of farm households ${ }^{1}$.

\footnotetext{
${ }^{1}$ The statistic of Chinese cooperatives has been obtained from the webpage: http://www.xinhuanet.com/fortune/201709/04/c_129695890.htm.
} 


\subsection{Literature review and problem statement}

Acknowledging the importance of cooperatives in agricultural development and rural development, many countries consider cooperatives as major policy tools to improve farmers' welfare (Mojo et al., 2017). Much research has been done on the effectiveness of cooperatives in Costa Rica, Ethiopia, Kenya and other developing countries. The findings indicate that cooperatives have positive effects on agricultural production, the adoption of agricultural technology, and farmers' incomes in general (Wollni and Zeller, 2007; Francesconi and Ruben, 2012; Abebaw and Haile, 2013; Chagwiza et al., 2016). Another major topic in research on cooperatives is the relationship between cooperatives and their members (Kalogeras et al., 2009; Cechin et al., 2013; Fischer and Qaim, 2014).

The rapid growth in the number of cooperatives in China has attracted much attention from academia. Chinese scholars have recently carried out studies on (1) the relationship between institutional settings and cooperative development (Deng et al., 2010; Zhang and Huang, 2014), (2) the impacts of cooperatives on farmers' income and agricultural development (Huang et al., 2008; Ito et al., 2012), and (3) the internal governance structure of cooperatives (Liang et al., 2015). This thesis can be placed in the second group of studies, as the focus is on the impact of cooperatives on the position and welfare of smallholder farmers in China given the two major challenges that Chinese smallholder agriculture is facing. Under this overarching theme, four issues that have received little or no attention in the literature so far will be explored.

First, the Chinese cooperatives' development status needs to be understood before their impact be assessed. According to the ICA principles ${ }^{1}$, a cooperative is owned, controlled and patronized by its members. Some scholars argue that Chinese cooperatives have deviated from the ICA principles by introducing shareholder-ownership and shareholder-benefit. Yuan (2013) claims that some Chinese cooperatives have muted into "strange animals". Others point out that Chinese cooperatives are experiencing problems such as rent seeking, and that small farmers are getting exploited by large farmers (Pan, 2011). A large number of farmers are still hesitant to join a cooperative even in areas where cooperatives are developing well. Understanding the (lack of) impact asks for an evaluation of the current development status of Chinese agricultural cooperatives.

\footnotetext{
${ }^{1}$ More contents about cooperative principles can be found on the webpage of International Co-operative Alliance. The website is: https://ica.coop/, which was last accessed to on 1-3-2018.
} 
Second, cooperatives enable farmers to bargain collectively with buyers of farm products (Bijman and Iliopoulos, 2014). Mujawamariya et al. (2013) and Milford (2014) analyse the reasons for producers' choice of different marketing outlets by comparing production costs and transaction costs involved in dealing with different buyers with different product and process requirements. However, the question whether cooperatives play a role in farmers' choice of marketing channels remains unanswered so far. Jia et al. (2012) analyse the main marketing channels of cooperatives in China and find that cooperatives mainly sell products to wholesale markets and facilitate farmers' access to markets by bridging farmers and agribusiness. Since they use the cooperative as the unit of analysis, they do not examine farmers' motivations for joining cooperatives, nor the impact of membership on farmers' choice of marketing channel.

Third, cooperatives are generally considered to be able to help farmers overcome market failures and increase agricultural income and thus reduce rural poverty (Markelova et al., 2009; Fischer and Qaim, 2012). Much research has examined cooperatives' effectiveness. On the one hand, Wollni and Zeller (2007) and Sauer et al. (2012) provide evidence that cooperatives improve the coffee and milk prices that farmers in Costa Rica and Commonwealth of Independent States (CIS) countries received, respectively. Abebaw and Haile (2013) and Verhofstadt and Maertens (2014) find that cooperatives promote the use of chemical fertilizers and agricultural innovations, which contributes to improved agricultural productivity and higher farm incomes. But Addai et al. (2014) find that farmer organization membership exerts no significant impact on the yields or technical efficiency of maize farmers in Ghana. Whether or not, and the way in which, cooperatives improve Chinese smallholders' economic status still needs to be examined.

The fourth issue relates to the sustainable development of cooperatives. Liang and Hendrikse (2013) argue that the genesis of cooperatives in China is not the result of bottomup collective action by small farmers, but is due to the political pressure and the converging interests of specific agricultural entrepreneurs. Deng et al. (2010) claim that the government is of primary importance in the establishment and growth of cooperatives after 2006. Most successful farmer cooperatives in western countries have been voluntarily initiated (Cook, 1995). Whether Chinese cooperatives can develop sustainably, given that the pursuit of potential policy benefits has been the important motivation for their formation (Deng et al., 2010), is an issue that deserves more research. 


\subsection{Research objectives and research question}

Most current research on farmers' cooperatives uses neoclassical microeconomic producer theory. However, the limitation of neoclassical economics is that it provides little insight in how to structure transaction relationships or the relationship between members and the cooperative. Socio-economic factors and psychological variables have received little attention, for example, when examining factors influencing farmers' decisions on marketing their products.

The objective of the study is to assess the impact of cooperatives on smallholder farmers in China by using transaction cost and other economic theories and taking into account socioeconomic and psychological factors. This objective will be realized by identifying and assessing economic and non-economic factors affecting Chinese farmers' choice of participating in cooperatives, evaluating the impact of cooperatives on farmers' choice of production behaviour and marketing channels, and discussing the possibility for cooperatives to sustainably develop.

To reach this objective, four specific research questions will be examined:

1. What are the developments and characteristics of farmers' cooperatives since 2007?

2. What are the effects of cooperative membership and other factors on farmers' choice of marketing channels?

3. What is the effect of cooperative membership on smallholder farmers' yields and profits, and how are the effects produced?

4. What factors influence member commitment to cooperatives?

\subsection{Methodology}

Both qualitative and quantitative research methods have been used to answer these questions. In Chapter 2, a comparative literature research is conducted to answer the $1^{\text {st }}$ research question. The evolution and characteristics of cooperatives in China in comparison with those in Western Europe are examined mainly from six key perspectives, based on an extensive review of both Chinese and English language literature on agricultural cooperatives. The English language literature referred in the thesis starts from 1940s onwards and the Chinese language literature mainly covers 2005 until 2017.

The answers of Questions 2 to 4 are based on field survey data collected among apple farmer households and apple farmer cooperatives. China is the world's leading producer of apples, producing roughly 55\% of the total apple output in 2015 (Frederick et al., 2015). Apples are 
the fruit crop with the largest acreage and the highest production value in China, and have been the dominant income source for farmers in the two main apple production regions - the Bohai Gulf area and the Loess Plateau area (Wang and Huo, 2014). Apple farming is typically done by smallholder farmers in these two regions; the average contracted farmland size is around 0.5 ha (Lin, 2017). Given the importance of the apple sector in China, insights into the effects of apple cooperatives on smallholder farmers will be very relevant for China's cooperatives policy. The field survey was conducted in Shaanxi Province (in the Loess Plateau area) and Shandong Province (in the Bohai Gulf area) between January and March, 2015.

A multistage sampling procedure was used for the selection of observation units. In the first stage, we used the probability proportional to size (PPS) method to select 7 out of the 10 most important apple production counties in Shaanxi and 8 out of the 10 most important apple production counties in Shandong, according to the size of apple production in 2014. In the second stage, we asked the Agricultural Bureau in each county for the list of apple cooperatives in the county; 5 cooperatives were randomly selected from those lists. Therefore, in total we first selected 75 cooperatives. However, the chairmen of 12 out of the 75 selected cooperatives could not be reached. Therefore, we dropped these 12 cooperatives from our sample, resulting in a final sample of 63 cooperatives that were interviewed (30 in Shaanxi and 33 in Shandong). We did face-to-face interviews with the chairperson or another official involved in managing the cooperative. Data about the cooperative (e.g., number of members, initiators) were also collected by interviewing the cooperative chairperson face-toface. Next, 10 - 12 farm households were interviewed in the village where the cooperative is located. At least 6 cooperative members in each village were interviewed. This gave a total number of 700 farm households that were interviewed, composed of 429 member households and 271 non-member households. Using a structured questionnaire, information was collected on apple production in 2009 and 2014 and apple marketing in 2014 (including input use, costs, yields, and output price), as well as household and farm characteristics (e.g., age, education, farm size, and investments), and farmers' perceptions about transactions. The collected information was based as much as possible on written records; for those farmers who did not keep records it was based on recall data. Question 2 is answered in Chapter 3 using transaction cost economics as the theoretical framework. Besides asset specificity in production, also geographical location and transaction uncertainty are incorporated in the framework. The main marketing channels for apple farmers are wholesalers, small dealers 
and cooperatives. To avoid losing relevant information about the households who sold their produce via two or more marketing channels, dummy variables for each of the channels used by the farmers in the sample are used as dependent variables. Given the potential endogeneity of cooperative membership when evaluating the effect of cooperative membership on farmers' choice of marketing channels, endogenous switching probit models are employed to estimate the determinants of cooperative memberships and the effect of memberships and other factors on farmers' choice among the three marketing channels.

Research question 3 is answered in Chapter 4 where endogenous treatment regression models (ETRM) are used to evaluate the treatment effect of cooperative membership on apple farmers' yields and profits per capita, respectively. A theoretical framework is developed based on the Cobb-Douglas production function. We hypothesize that cooperative services give member farmers an edge in production. ETRM allows interactions between treatment and outcome covariates, through which we can obtain insights into the pathways through which different outcomes for members and non-members are produced.

Chapter 5 answers the fourth research question by employing structural equation models and is based on Allen and Meyer's (1990) three-component model of commitment. Given the important role of the chairperson in the development of Chinese cooperatives and the Confusion cultural characteristics of Chinese society, trust in the leadership and social pressure are the foci of factors influencing member commitment. Structural equation models make it possible to explore the underlying mechanism by which trust and social pressure influence member commitment. Data of 391 apple cooperative members are used for the analysis.

Chapter 6 presents the general conclusion and discussion of the whole thesis. The results from the previous chapters are synthesized and a general discussion on the research objective and the main findings is presented in this chapter.

\subsection{Policy relevance}

The thesis contributes to the understanding of the current status of cooperatives in China and their impact on smallholder farmers. Specifically, it summarizes characteristics of cooperatives and factors influencing their evolution, evaluates the effects of cooperatives on farmers' choice of marketing channels and on the yield and profits from produce, and examines the factors influencing member commitment to cooperatives. The results and 
conclusions of the analyses provide important novel insights into the effects of the ongoing policy of promoting farmers to participate in farmer cooperatives. They may also be very relevant for policies promoting integration of stallholders into high-value chains in other developing countries with large numbers of small and fragmented farms such as Vietnam. The reasons why smallholders participate (or not) in cooperatives with Chinese characteristics are explored from the perspective of farmer households while taking the influence of local governments into account. The insights obtained from the analysis will be relevant for policies aimed at promoting farmer membership of agricultural cooperatives. A sound understanding of the evolution and characteristics of cooperatives in China in comparison with those in Western Europe can assist Chinese policy makers in evaluating the current cooperative policy and developing future policies based on lessons learned in other countries. Insights into factors affecting the choice of marketing channels by farmers are particularly relevant for policies that aim at promoting smallholders' involvement in highvalue food chains through facilitating their participation in cooperatives. The findings of the chapter on the impact of cooperatives on yields and profits are expected to contribute to policy making in the field of developing modern agriculture, and specifically the role of cooperatives and other types of agricultural business entities in this respect $(\mathrm{Hu}, 2012)$. The conclusions drawn with respect to factors affecting member commitment can provide important insights into the effectiveness of policy instruments aimed at making cooperatives develop sustainably in the Chinese cultural environment. 


\section{References}

Abebaw, D., Haile, M. G., 2013. The impact of cooperatives on agricultural technology adoption: Empirical evidence from Ethiopia, Food Policy. 38, 82-91.

Abebe, G. K., Bijman, J., Kemp, R., Omta, O., Tsegaye, A., 2013. Contract farming configuration: Smallholders' preferences for contract design attributes, Food Policy. 40, 14-24.

Addai, K. N., Owusu, V., Danso-Abbeam, G., 2014. Effects of farmer-Based-organization on the technical efficiency of maize farmers across Various Agro-Ecological Zones of Ghana, Journal of Economics and Development Studies. 2, 141-161.

Allen, N. J., Meyer, J. P., 1990. The measurement and antecedents of affective, continuance and normative commitment to the organization, Journal of occupational psychology. 63, 1-18.

Bijman, J., 2016. The changing nature of farmer collective action: Introduction to the book, in J. Bijman, R. Muradian and J. Schuurman eds., Cooperatives, Economic Democratization and Rural Development. Edward Elgar Publishing Ltd., Cheltenham, UK.

Bijman, J., Iliopoulos, C., 2014. Farmers' cooperatives in the EU: Policies, strategies, and organization, Annals of Public and Cooperative Economics. 85, 497-508.

Cechin, A., Bijman, J., Pascucci, S., Omta, O., 2013. Decomposing the Member Relationship in Agricultural Cooperatives: Implications for Commitment, Agribusiness. 29, 39-61.

Chagwiza, C., Muradian, R., Ruben, R., 2016. Cooperative membership and dairy performance among smallholders in Ethiopia, Food Policy. 59, 165-173.

Cook, M. L., 1995. The future of US agricultural cooperatives: A neo-institutional approach, American Journal of Agricultural Economics. 77, 1153-1159.

Deng, H., Huang, J., Xu, Z., Rozelle, S., 2010. Policy support and emerging farmer professional cooperatives in rural China, China Economic Review. 21, 495-507.

Fischer, E., Qaim, M., 2012. Linking smallholders to markets: Determinants and impacts of farmer collective action in Kenya, World Development. 40, 1255-1268.

Fischer, E., Qaim, M., 2014. Smallholder Farmers and Collective Action: What Determines the Intensity of Participation?, Journal of Agricultural Economics, 1-20.

Francesconi, G. N., Ruben, R., 2012. The hidden impact of cooperative membership on quality management: A case study from the dairy belt of Addis Ababa, Journal of Entrepreneurial and Organizational Diversity. 1, 85-103.

Frederick, C., Liu, M., Wu, B., 2015. 2015 Fresh Deciduous Fruit Annual for China. GAIN Report, USDA, Washington, D.C.

Fritz, M., Schiefer, G., 2008. Food chain management for sustainable food system development: a European research agenda, Agribusiness. 24, 440-452.

Huang, J., Wu, Y., Zhi, H., Rozelle, S., 2008. Small holder incomes, food safety and producing, and marketing China's fruit, Applied Economic Perspectives and Policy. 30, 469-479.

Ito, J., Bao, Z. S., Su, Q., 2012. Distributional effects of agricultural cooperatives in China: Exclusion of smallholders and potential gains on participation, Food Policy. 37, 700-709.

Jia, X., Huang, J., Xu, Z., 2012. Marketing of farmer professional cooperatives in the wave of transformed agrofood market in China, China Economic Review. 23, 665-674.

Kalogeras, N., Pennings, J. M., van der Lans, I., Garcia, P., van Dijk, G., 2009. Understanding heterogeneous preferences of cooperative members, Agribusiness. 25, 90-111.

Liang, Q., Hendrikse, G., 2013. Core and common members in the genesis of farmer cooperatives in China, Managerial and Decision Economics. 34, 244-257.

Liang, Q., Hendrikse, G., Huang, Z., Xu, X., 2015. Governance Structure of Chinese Farmer Cooperatives: Evidence From Zhejiang Province, Agribusiness. 31, 198-214.

Lin, W., 2017. Farmland scale: International experiences and China's option Issues in Agricultural Economy, 33-42. (in Chinese)

Markelova, H., Meinzen-Dick, R., Hellin, J., Dohrn, S., 2009. Collective action for smallholder market access, Food policy. 34, 1-7.

Milford, A. B., 2014. Co-operative or coyote? Producers' choice between intermediary purchasers and Fairtrade and organic co-operatives in Chiapas, Agriculture and human values. 31, 577-591.

Mojo, D., Fischer, C., Degefa, T., 2017. The determinants and economic impacts of membership in coffee farmer cooperatives: recent evidence from rural Ethiopia, Journal of rural studies. 50, 84-94.

Mujawamariya, G., D’Haese, M., Speelman, S., 2013. Exploring double side-selling in cooperatives, case study of four coffee cooperatives in Rwanda, Food Policy. 39, 72-83.

Narrod, C., Roy, D., Okello, J., Avendaño, B., Rich, K., Thorat, A., 2009. Public-private partnerships and collective action in high value fruit and vegetable supply chains, Food Policy. 34, 8-15. 
Pan, J., 2011. Specialized Farmers' Cooperatives in China: The Interpretation of the Data of their Development, China Rural Survey. 6, 2-11. (in Chinese)

Reardon, T., Barrett, C. B., Berdegué, J. A., Swinnen, J. F., 2009. Agrifood industry transformation and small farmers in developing countries, World development. 37, 1717-1727.

Sauer, J., Gorton, M., White, J., 2012. Marketing, cooperatives and price heterogeneity: evidence from the CIS dairy sector, Agricultural Economics. 43, 165-177.

Tan, S., Heerink, N., Qu, F., 2006. Land fragmentation and its driving forces in China, Land Use Policy. 23, 272-285.

Tran, N., Bailey, C., Wilson, N., Phillips, M., 2013. Governance of Global Value Chains in Response to Food Safety and Certification Standards: The Case of Shrimp from Vietnam, World Development. 45, 325336.

Verhofstadt, E., Maertens, M., 2014. Smallholder cooperatives and agricultural performance in Rwanda: do organizational differences matter?, Agricultural Economics. 45, 39-52.

Wang, L., Huo, X., 2014. Transaction costs comparison between cooperatives and conventional apple producers: A case study of northwestern China Ann. Public Coop. Econ. 85, 233-255.

Wollni, M., Zeller, M., 2007. Do farmers benefit from participating in specialty markets and cooperatives? The case of coffee marketing in Costa Rica, Agricultural Economics. 37, 243-248.

Yuan, P., 2013. Study on the mutation of Chinese characteristic cooperatives, China Rural Survey. 3, 40-46. (in Chinese)

Zhang, Y., Huang, Z. H., 2014. Identifying risks inherent in farmer cooperatives in China, China Agricultural Economic Review. 6, 335-354. 


\title{
2. Development and Characteristics of Farmers' Cooperatives in China: A Review and Comparison ${ }^{1}$
}

\begin{abstract}
The purpose of this paper is to obtain a better understanding of the development of Chinese farmer cooperatives by exploring and discussing the underlying causes of the different characteristics and development paths of Chinese and Western European cooperatives in agricultural markets. The paper compares the evolution and characteristics of cooperatives in China with those in Western Europe, based on an extensive review of both Chinese and English language literature on agricultural cooperatives. Differences in development between Chinese and Western European cooperatives can be explained by six key aspects: genesis, legal framework, financial structure, membership characteristics, internal governance and the relationship between cooperatives and the (local) government. While Chinese agricultural cooperatives have been growing rapidly in number and scope, scholars differ in their assessment of the effectiveness of these organizations for improving farmers' income and rural development. Part of this disagreement originates from lack of understanding of the key characteristics of the cooperatives. By comparing Chinese with Western European cooperatives, and embedding the comparison in the international literature on cooperatives, we provide better insights into what can be expected from Chinese cooperatives.
\end{abstract}

Key words: legal requirements, membership heterogeneity, financial structure, internal governance, government relations

Abbreviations used: EU (European Union); BoD (Board of Directors); GA (General Assembly); ICB (Industrial and Commercial Bureau); SB (Supervisory Board);

\footnotetext{
${ }^{1}$ Unpublished paper by Jinghui Hao, Jos Bijman, Wim Heijman and Nico Heerink.
} 


\subsection{Introduction}

The development of Chinese cooperatives has been a complicated story. In the 1950s and 1960s, agricultural cooperatives evolved into "people's communes", which used to be the basis of Chinese agriculture and the basic unit of the rural administration before 1983. The Great Leap Forward Movement (1958-1961) led to the agricultural crisis 1959-1961 and resulted in thirty million deaths through famine (Lin, 1990). This disaster was a great constraint for any type of agricultural collective economy. However, in the late 1980s, with problems in marketing of agricultural products, some farmers, especially those with large farms, began to collaborate voluntarily to form cooperatives. These are considered as the embryo of the new generation of Chinese professional farmer's cooperatives (Huang et al., 2010)

In contrast, cooperatives in the Western world has been undergoing the prosperous and vigorous development for a long time and have been playing an important role in European agriculture. The European Union has about 22,000 operating cooperatives, with 6.2 million farmer-members (COGECA, 2015). Although the number of cooperatives is constantly declining, their market share has not been reduced. For the EU as a whole, cooperatives market $40 \%$ of all agricultural products, but in countries in the north-west of Europe, cooperatives have market shares up to $80 \%$ (Bijman and Iliopoulos, 2014). While agricultural cooperatives have been established to bring economic benefits to their farmer-members, they have also been helpful in tackling social issues, for instance in mitigating poverty and promoting rural community development (Kalmi, 2007).

The first Chinese national law on cooperatives, the Law on Specialized Farmers Cooperatives of China, was promulgated in July 2007. Since then the development of cooperatives has been facilitated by supportive policies, including tax exemption, financial subsidies and preferential credit programs. With this government support, the number of Chinese agricultural cooperatives has increased rapidly. By the end of 2014, the number of registered farmers' cooperatives reached almost 1.3 million (SAIC, 2015), which is 3.7 times as high as the total number of agricultural cooperatives in 2010. In 2014, around one third of Chinese farmers were participating in at least one cooperative. The rapid growth in the number of cooperatives has attracted much attention from the Chinese academic world. Scholars have recently carried out studies ranging from analysis of the relationship between political and institutional settings and cooperative development, through the impacts of cooperatives on 
farmers' income and agricultural development, to studies on the inner governance structures of cooperatives.

Though the number of registered agricultural cooperatives has been expanding rapidly, scholars question how many of them are actually functioning well. Ma (2013) claims that in the "jungle of the vast number of cooperatives", some cooperatives have mutated into "strange animals". At the same time, Yuan (2013) complains that the basic principles of member-ownership and member-benefit has transformed into shareholder-ownership and shareholder-benefit. In contrast to the enthusiasm in most of the academic world and policy circles, large numbers of farmers are still hesitant to join cooperatives even in areas where cooperatives are doing well. Pan (2011) found that the phenomena of "bogus cooperatives", "rent seeking" and "big farmers bullying small farmers" are ubiquitous among Chinese cooperatives, leading various scholars to re-examine whether Chinese cooperatives actually work in the interest of their farmer-members.

With the rapid changes in the cooperative landscape and the conflicting viewpoints presented by scholars, it is hard for readers from Europe to fully understand what cooperative development in rural China really means. It is the objective of this paper to shed more light on the recent development of Chinese farmer cooperatives and their impact on farmers' incomes and rural development. The paper does so by exploring and discussing the main differences and the underlying factors between agricultural cooperatives in China and those in Western Europe. While the number of studies on farmer cooperatives in China is increasing, a comparative analysis has not been done yet. Our paper is based on a thorough review of the literature both in Chinese and English languages on agricultural cooperatives. The structure of this paper is as follows. We present and discuss the differences between European and Chinese cooperatives on six different aspects, each in a separate section. Thus, section 2 presents the genesis of cooperatives, using a historical perspective. Section 3 discusses the legal requirements for cooperatives. Section 4 presents the finance of cooperatives. Section 5 discusses the extent of membership heterogeneity. Internal governance is presented in section 6. Section 7 discusses the relationship between cooperatives and the government. The concluding section presents a discussion on the efficacy of Chinese cooperatives in strengthening the position of (smallholder) farmers in agricultural markets. 
We also provide a comprehensive picture of the advances and trends of research in agricultural cooperatives by Chinese scholars. We review peer-reviewed articles published in the six most highly ranked Chinese agricultural economics journals published in the Chinese language. The journals are China Rural Survey, China Rural Economy, Issues in Agricultural Economy, Journal of Agro-technical Economics, Rural Economy, and Agricultural Economy. Based on our review, we generate interesting observations in the research of agricultural cooperatives by the Chinese scholars. These observations can provide valuable information and models for future research in Chinese agricultural cooperatives as well as agricultural cooperatives in other developing countries.

\subsection{The genesis of cooperatives}

The history of cooperatives in Europe dates back to the mid of 19th century. Also in North America and Oceania, cooperatives emerged in the second half of the 19th century (Fernández, 2014). The formation of the Rochdale Society of Equitable Pioneers took place in Great Britain in 1844; the Society aimed to improve its members' living conditions, by reducing the cost of food, and increasing employment and education opportunities. In Germany, the first Raiffeisen Bank was established in 1864, which is considered as a milestone in the development of cooperatives. The main objective of Raiffeisen was to provide savings and credit services in rural areas based on the idea of 'self-help'.

The set-up of Danish cooperatives in the 1880s was closely linked to the threats of both cheap imported grain and the decrease of tariff protection, which impelled farmers to shift to high value-added products such as bacon and butter (Gutierez et al., 2005). Similarly, the establishment of cooperatives in France and the Netherlands can also be considered as farmers' response to the crisis in the agricultural economy in the late 19th century. In 1877, farmers in the Netherlands established the first cooperative for the purchase of good quality chemical fertilizers (Gutierez et al., 2005). In the 1880s, French farmers formed a union for the joint purchase of fertilizers in an attempt to countervail merchant power (Dedieu and Courleux, 2011).

According to Chloupkova (2002), the most important reason for establishing farmers' cooperatives in EU countries was the economic challenges that small farmers were facing. With the imbalance in bargaining power, agricultural producers needed institutional arrangements to improve their economic conditions and to mitigate the reverse effects of 
market failures. In the words of Cook (1995), the entrepreneurial energy in the first stage of the agricultural cooperative lifecycle was rooted in a survival-defensive strategy.

Establishing federations, or cooperatives of cooperatives, have supported the development of local cooperatives, both by influencing government policies and by setting up joint businesses at the regional and national level. The genesis and prosperity of the Finnish agricultural cooperative is evidence of this claim. Finland, where the farmers have always had a tradition of cooperation, experienced a rapid growth in cooperatives after the setting-up of a central organization, the Pellervo Society (now Finnish Cooperatives Pellervo).

Agricultural cooperatives have been playing an important role in the Finnish agricultural sector since the beginning of the 20th century, accounting for more than half of the market for most food products (Pyykkönen et al., 2012).

The genesis of most Chinese cooperatives has been on a different basis. Before 2006, the development of agricultural cooperatives was slow. For instance, only $2 \%$ of Chinese farmers belonged to cooperatives in 2005 (Huang and Rozelle, 2015). Several scholars used research on cooperatives to show the necessity to develop farmers' cooperatives and to establish the legal status of cooperatives in China. They argued that cooperatives were needed to improve the negotiation and competitive position of farmers in the market, to lower transaction costs for individual farmers, and to develop a regional agricultural economy (Huang, et al., 2010; Zheng et al., 2012; Peng and Yuan, 2014).

Since 2007, various new breeds of farmers' cooperatives have appeared and the number of officially registered cooperatives has been soaring. By the end of 2014, the percentage of farmers participating in cooperatives reached around 30\% (SAIC, 2015). This large increase is not a coincidence. The Chinese government has played a major role as catalyst in the establishment of new cooperatives. Based on a national survey of 380 villages in 2003 and 2009, Deng et al. (2010) found that the quest for economic benefits is the farmers' main motivation to join cooperatives, but that the role of the government is crucial for establishing cooperatives. Liang and Hendrikse (2013) support this claim with their empirical study and find that the genesis of cooperatives in China is not the result of bottom-up collective action by small farmers, but is due to the converging interests of specific agricultural entrepreneurs and the political pressure.

In terms of the genesis of farmers' cooperatives, we can see a major difference between European and Chinese cooperatives. While the former was established bottom-up by farmers 
themselves, motivated by the need to solve economic challenges, the latter are the result of the collaboration between entrepreneurs and local governments. We call this the external or top-down approach to cooperative initiation.

\subsection{Legal requirements of cooperatives}

Cooperatives have a long history in Europe. Most EU countries, especially the Western and Northern European nations, established cooperative laws more than a century ago. These laws have promoted the development of cooperatives, and legal reforms have proceeded hand in hand with the cooperative development (Fici, 2013). Though cooperative laws differ in each country, they generally show more similarities than divergences. The legislation on cooperatives in the Netherlands can be considered an example of cooperative development in North-West European. We will compare Dutch and Chinese cooperative law when we elaborate on the differences of legal status between Chinese and European cooperatives.

Dutch Cooperative Law provides the following definition of a cooperative: "A cooperative is a legal person. It is established by at least two incorporators, and must have two or more members at incorporation. At least two of these initial members must also be incorporators of the cooperative. After its incorporation the cooperative may have a single member. The name of the cooperative must include the word 'coöperatief' or 'coöperatie'. (...) Both natural persons and legal entities may be members of a cooperative".

In China, registration at the Industrial and Commercial Bureau (ICB) constitutes the official establishment of Chinese specialized farmers' cooperatives. According to Chinese cooperative law, a cooperative is a legal person, and can be registered without fees in the ICB by "at least five (5) or more citizens, including the firms and other entities related to the production and operation activities of the cooperatives, or benefiting from the service by cooperative". The law also stipulates that in a farmers' cooperative more than $80 \%$ of the members have to be farmers. An easy registration procedure facilitates farmers to establish cooperatives efficiently. However, the low cost of registration without further monitoring and control has been considered a weakness in the law that encourages the existence of "fake cooperatives" which are only established for obtaining subsidies or other state benefits (Pan, 2011). 
As to the funding and profit distribution rules, Dutch cooperatives have clearly stipulated. "There are no statutory minimum capital requirements in respect of the cooperative. The members may provide funds to the cooperative in the form of loans or capital, but this is not mandatory. The profits of the cooperative may be allocated to the members' capital or reserve account or may be distributed to its members directly. (...) Any distribution or allocation to the capital or reserve account can be made irrespective of the funds contributed by each member".

Chinese Cooperative Law has similar profit distribution rules to Dutch Cooperative Law. The difference between the two laws is in the percentage of distributed profits. According to Chinese Cooperative Law, "the distributed profits should be allocated to the members based on their turnover with the cooperative, and the percentage of profits allocated to the members must exceed $60 \%$ of the total yearly profits".

Another obvious difference between Chinese and European cooperative law is about the decision making process and the distribution of votes among members. According to Chinese cooperative law, "each member has one basic vote. Additionally, the members with a large share in the equity capital of the cooperative or the ones with a large trading volume with the cooperative can have additive voting rights. The additional votes cannot exceed $20 \%$ of the total basic votes (which are the total votes without additional votes) in the cooperative." Allowing additional voting rights is one of the most important origins of membership heterogeneity (see section 4).

We can conclude that the main differences between the legal characteristics of Chinese and Dutch cooperatives lie in the decision control rights and residual claim rights. Chinese Cooperative Law allows the existence of additional voting rights per member according to that member's share in the equity capital of the cooperative or the trading volume with the cooperative, while there is no such rule in Dutch or other European cooperative laws.

Additionally, Chinese Cooperative Law has a clear minimum percentage of distributed profits of the cooperative, while there is no such requirement regarding profit distribution in Dutch cooperative law. 


\subsection{Membership heterogeneity}

The topic of membership heterogeneity and its impact on the behavior of the cooperative has interested scholars ever since the 1950s. According to Kaarlehto (1955) and Ohm (1956), the cooperative can be viewed as a coalition of participants with different goals, and the behavior of the cooperative can be seen as a result of negotiation among different members (Valentinov and Iliopoulos, 2013). Generally, uniformity of member interests is critical for marketing cooperatives because it minimizes costs of collective decision-making (Hansmann, 1999). An increase in member heterogeneity leads to higher decision-making costs and reduced strategic focus. The decision-making costs may include the costs of collecting and processing information from members with diverse interests as well as influence costs stemming from (groups of) members trying to steer decision making towards their private interests. Membership heterogeneity problems have been grouped into the following categories: free rider problems, horizon problems, portfolio problems, control problems and influence cost problems (Milgrom and Roberts, 1990; Cook, 1995; Iliopoulos and Hendrikse, 2009).

Membership heterogeneity may be due to geographic dispersion, different commodities produced or inputs purchased by the members, the variance in members' age, educational levels, farm size, the percentage of non-farm income, or differences in business objectives (Cook and Iliopoulos, 1999). Particularly, differences in the quality of the products that members deliver may negatively influence the daily operations of the cooperative. If members deliver different qualities but get paid an average price, the high quality producers are likely to leave the cooperative and look for alternative market outlets. This adverse selection problem will leave the cooperative with only the inefficient or low quality producing members, which may threaten the competitive position of the cooperative (Karantininis and Zago, 2001).

In addition, member heterogeneity impacts the internal governance structure of cooperatives. Kalogeras et al. (2009) found that different business sizes and attitudes toward risks affect members' preferences for internal governance. In general, the less risk-averse members with large scale operations prefer more professional managers in the decision-making position, while the more risk-averse members prefer decisions to be taken by their representatives. Osterberg and Nilsson (2009) found that the diversity of members' attributes, particularly the diversity of members' perception of their participation in the governance of the cooperative, 
has a large impact on members' satisfaction with the service provided by the cooperative as well as their assessments of their cooperative's degree of success.

As for the problem of membership heterogeneity in Chinese cooperatives, Huang and Shao (2009) pointed out that because of differences in production scale, various technical and management levels and distinctive attitudes to risks, memberships in Chinese cooperatives show substantial levels of heterogeneity. This membership heterogeneity can be traced back to the initiation of the cooperative. The legal option of multi-membership, ranging from individual farmers to agribusiness companies, allows the existence of large differences among members in scale of production, capital holdings and social capital.

The increasing number of cooperatives has been initiated by dragon-head firms, big farmers and agro-technical organizations (including inputs merchants) while the number of traditional cooperatives initiated by ordinary farmers have been shrinking (Cui and Xie, 2014). In addition, the existence of "bogus cooperatives", "elite capture in the cooperative" and "smallscale farmers exploited and bullied by big farmers" have drawn heated debate in academic circles about the essence of the cooperative (Xu, 2012; Sun, 2014).

Because of the diversity in holding capital shares, farmer households will be vulnerable to exploitation by those members who are large shareholders (Wen, 2009). The members with additional voting rights are the so-called core members, while those who invest only a small amount in capital shares or pay only an entry fee when joining the cooperative are called common members (Liang and Hendrikse, 2013). This leads to a stratified membership and divergent influence on decision-making. For example, in a cooperative initiated by a dragonhead company, the company is often one of the core members, holding a substantial share in the equity capital (Zhang, 2009).

We can learn from this part that due to the stratified membership, Chinese cooperatives are more likely to have membership heterogeneity problems than the European ones, particularly due to the large inequality among members in terms of the number of capital shares they hold. The large membership heterogeneity may have a negative influence on the efficacy of Chinese cooperatives, and it is also considered a constraint on cooperative development as small-scale farmers are often exploited and bullied by big farmers and agribusiness entrepreneurs. 


\subsection{Cooperative finance}

Finance is crucial to the success of the cooperative. The three basic cooperative principles, namely user-ownership, user-control and user-benefit (Dunn, 1988), are tied to each other by the members' financial stakes in the cooperative. Failure of members to maintain financial contribution to the cooperative may jeopardize the very existence of the cooperative.

Particularly in the formation stage of the cooperative, member contributions are crucial, but also difficult. According to a survey by Bhuyan and Leistritz (2001), raising equity and debt capital rank first and second respectively amongst the most important problems for a cooperative in the start-up stage

In Europe and North America, cooperatives have three main sources of capital. First, members contribute by paying membership fees. Second, members buy membership shares. Third, members purchase investment shares. However, the most important source of capital for the cooperative is retained earnings. This means that a cooperative do not distribute all surplus to its members, but add part of it to the general reserves. The percentage retained earnings can differ per cooperative. In addition to these sources of equity capital, cooperatives may raise debt capital. Debt capital is money borrowed with a legal obligation to repay it under stated interest rates, terms, and conditions. Agricultural cooperatives use many of the same debt capital sources as other businesses, although it more common for agricultural cooperatives to obtain loans from cooperative banks.

Marketing cooperatives operating in highly competitive markets often need more equity capital than their members can or are willing to contribute. One of the classical strategies for a cooperative to grow without obtaining additional equity capital is merge with another cooperative (Richards and Manfredo, 2003). If mergers are not attractive, and members cannot contribute more capital, outside investors may be an option (Chaddad and Cook, 2004). For instance, in The Netherlands and Finland cooperative law allows equity capital investment from outsiders (Brusselaers et al., 2014). This cooperative financial strategy may have implications for the internal governance structure of cooperatives (Bijman et al., 2014). Unlike European cooperatives, where equity capital is provided by all members together (either as investment or through retained earnings), the equity capital of Chinese cooperatives mainly comes from a small portion of members (the core members) and from subsidies provided by the government (Yuan and Gao, 2012). Finance is seen as the largest difficulty for the development of Chinese cooperatives, because most of the smallholder members do 
not have capital to invest in their cooperative (Wang and Dong, 2009; Zheng et al., 2011). In addition, cooperatives have difficulties in obtaining loans from commercial banks. Some cooperatives receive financial support from the local government.

We thus can summarize that the main difference in finance between Chinese cooperatives and their European counterparts are shown in the difference in development stage. In the start-up phase, Chinese cooperatives rely heavily on the core members, who constitute a small portion of the total members, while the start-up capital of the cooperatives in the EU is contributed by all members. Moreover, in the later stage of development, some Chinese cooperatives receive financial support from the government, which composes part of the capital needed for their development. However, European cooperatives' additional capital mainly comes from retained profits and members' additional investments.

\subsection{Internal governance}

A cooperative is owned and democratically controlled by its members and the members are the users of the services provided by the cooperative (Dunn, 1988). The internal governance of the cooperative is about how the members determine the strategies and policies of the cooperative. Thus, the internal governance refers to the allocation of control rights, which in turn affects the allocation of residual claim rights (Bijman, et al., 2014).

As cooperatives operate in a dynamic environment, with changing market conditions, policies and technology, it is important that cooperatives are able to adapt their internal governance to the changing circumstances (Mooney, 2004; Yu et al., 2015). Also McMaster (McMaster, 1996) stressed the importance of organizational adaptability, claiming that networks that seek commercial success must develop and maintain the ability not only to change in the face of highly competitive environments, but also to adapt in ways that influence that environment. Generally, the traditional model of the European cooperative governance has evolved into Northern European model and Southern European model (Chaddad and Iliopoulos, 2013). The traditional model consists of the General Assembly (GA) and Board of Directors (BoD), which are mandatory by cooperative law, and a Supervisory Board (SB). In Northern Europe, the traditional model has evolved into three other models: the extended traditional model, the managerial model and the corporate model (Bijman et al., 2013). By contrast, the dominant models of internal governance of cooperatives in Southern Europe are the traditional and extended traditional models (Rebelo et al., 2008; Bono, 2012). 
Specifically, the extended traditional model includes professionals who manage the cooperative enterprise. With the increasing scale and complexity of cooperatives and the market-oriented strategies adopted, cooperatives more often employ professional managers to take over the executive tasks of the BoD (Bijman et al., 2014).The managerial model consolidates the $\mathrm{BoD}$ and the professional management, where only professional managers make up the BoD to carry out the management activities, whereas the corporate model consolidates the $\mathrm{SC}$ with the $\mathrm{BoD}$ and forms an extended $\mathrm{BoD}$, where most decision rights are delegated to professional managers and the $\mathrm{BoD}$ is merely in charge of decision control (Chaddad and Iliopoulos, 2013). This trend has been foreseen by Hind (1999) in the research on the cooperative life-cycle, where she concludes that with the growth of the cooperative and the increasing membership heterogeneity it is inevitable that the decision-making rights will shift from the members to the managers.

The majority of Chinese agricultural cooperatives have a similar basic internal governance structure as Western cooperatives, consisting of a General Assembly, a Board of Directors and a Supervisory Board. The BoD, as the main body of decision-making, is often comprised of the initiators and core members of the cooperative. Liang et al. (2015) investigated 37 farmer cooperatives in Zhejiang Province in 2010 and found that the cooperatives had merged BoD and management and that this management team consisted of only core members. The GA, however, does not have the decision-making role as cooperative legislation prescribes. The GA is often used by the managers of the cooperative popularize agricultural production techniques and to inform members about the government's agricultural policies (Liang, et al., 2015).

The initiator of the Chinese farmer cooperative can be an influential figure in the village, or someone who used to work in the government or used to be a wholesaler of agricultural products (Zhang and Huang, 2014). This initiator usually becomes the chairman of the board. Compared with ordinary farmers (i.e., common members), the chairman holds "better knowledge regarding production technologies, asset capital, marketing capabilities, and social networks" (Lin and Huang, 2007), and has good connections with the local government. As to the allocation of decision rights in Chinese farmer cooperatives, Liang et al. (2015) found that the cooperative is dominated by the core members, as $92 \%$ of decisions is made by the chairman and the core members without consulting the common members. Since core members hold more shares in the cooperative than the common ones, core members also receive a higher share of the surplus generated by the cooperative (Liang, et al., 2015). 
Last but not least, the Chinese cooperatives are hardly ever managed by outside professionals. Liang et al. (2015) found that all chairmen are cooperative members, more specifically core members. Due to a lack of working capital, employing managers from inside instead of outside can be a preferable choice for most of Chinese cooperatives at the current stage. These chairmen/managers will be self-motivated and devote their own resources and social capital to the cooperative (Huang and $\mathrm{Xu}, 2008$ ). However, (Ma and Meng, 2008) point out that the common members can be exploited by the core members in case the BoD chooses to hide financial information from the common ones, and the SB colludes with rather than supervises the BoD. Furthermore, chairmen may have a constraining effect on the development of the cooperative due to their lack of professional knowledge and skills, particularly related to marketing (Liang and Hendrikse, 2013).

Part of the research on internal governance of Chinese cooperatives focuses on residual claim rights. To solve the financial constraint confronted by most Chinese cooperatives, the government encourages capital investment in the countryside and attracts dragon-head companies to set up cooperatives. These two strategies have been viewed as the causes of the strange mutations currently seen among Chinese cooperatives, as they blur the boundaries between cooperatives and investor-owned firms (Sun, 2003).

In short, Chinese cooperatives follow the traditional model of internal governance, while Northern and Southern European cooperatives seen an evolution in their internal governance models. On the one hand, in the life span of the European cooperative, the decision-making rights gradually shift from the members to the professional management. On the other, the decision rights in Chinese cooperatives are usually held by a small group of members, namely the core members.

\subsection{Relationships between cooperatives and the government}

The government has been playing an important role and has been considered as the main external support for developing cooperatives (Fock and Zachernuk, 2006). Because of freerider problem, lack of experience, low trust among potential members, and high organizational costs, it is often difficult for farmers to set up a new cooperative without external support (Ostrom, 1990; Fairbairn, 2004). Many governments around the world have been involved in cooperative development. According to Iliopoulos (2013), public support comes in different forms: (1) provision of a friendly legal framework, where friendliness in 
this context implies that the legal framework does not discriminate against cooperatives in any way; (2) exemption from anti-trust laws and regulations; (3) beneficial tax treatment; (4) access to favorable credit terms; and (5) technical assistance. "The intensity and mix of policies supporting agricultural cooperatives vary significantly from country to country" (Iliopoulos, 2013: 243).

From the rapid development agricultural cooperatives in China after 2007 it is obvious that government support has been quite important. The provincial ministries of agriculture are responsible for promoting and fostering farmer cooperatives. The relationship between the government and the cooperative can be mutually beneficial. To respond to the central government's call, local governments may use the growth in the number of the cooperatives as one of the criteria for judging the performance of particular officers. Some local governmental officers even initiate cooperatives themselves. This government push could also be the cause of the large number of so-called fake cooperatives, i.e. cooperatives that only exist on paper (Pan, 2011; Deng and Wang, 2014),

The cooperatives receiving governmental support usually have the stronger economic status, and are therefore called pilot cooperatives (Peng and Yuan, 2014). However, government support is not available for all cooperatives. Pilot cooperatives and dragon-head companies have received most of the subsidies and other benefits due to their better connections with the local government. In contrast, many cooperatives initiated by common farmers have found themselves out of the reach of policy support (Yuan, 2013). The cooperative chairman, who usually has strong ties with the local government, plays a critical role in communicating with the government and obtaining subsidies. For local governments it is easier to support cooperatives of members that already have a strong economic position, such as large-scale farmers or agribusiness firms, rather than to support cooperatives of only small farmers. Also the political gain is likely to be higher when the local government is collaborating with the more advanced farmers (Wen, 2013).

In general, Chinese cooperatives seem to have closer connections with the local government than their European counterparts. The close relationship is mainly due to the political interest local governments have in establishing cooperatives. 


\subsection{Conclusion}

Cooperatives are important in agricultural industries throughout the world, as they have a major impact on farmers' income and rural development (Bijman, 2016). This paper has compared Chinese cooperatives with their European counterparts in order to obtain a better understanding of the factors that cause Chinese cooperatives to follow their own evolutionary path.

The main difference between China and other Western countries in the genesis of the cooperatives lies in the distinctive motivations. The cooperatives in the Western world originated from intrinsic self-defense because of economic challenges, which can be generally categorized as a bottom-up. By contrast, the establishment of Chinese cooperatives was the result of the combination of (top down) political pressure with agribusiness entrepreneurs recognizing economic opportunities in changing market conditions. These entrepreneurs had strong social networks and close connections with local governments. Finance plays a critical role in the start-up of a cooperative, but it also has a strong influence on the success of the cooperative in later stages. Chinese cooperatives receive the largest part of their equity capital from a small group of members, the core members. While this may provide the cooperative with sufficient capital for building their competitive position, it holds the risk that common members are less committed, because the uneven distribution of shares is accompanied by an uneven distribution of decision-rights. European cooperatives do not face this problem, as all members contribute a similar share of equity capital.

The main differences in terms of the legal characteristics of cooperatives is the legitimacy of additional voting rights in decision control in the legal framework of Chinese farmers' cooperative versus the strict one-member one-vote principle which is the foundation of the democratic decision-making in cooperatives European countries. Nonetheless, both Chinese and Western cooperatives have certain legal characteristics in common, especially the flexible rules about formation and membership.

Both Chinese and Western cooperatives need to deal with membership heterogeneity. However, since the cooperatives are at different life cycle stages, heterogeneity has different impacts on them respectively. In Europe, increasing membership heterogeneity has become a barrier to seeking further risk equity and efficient decision making. As Chinese cooperatives are in an early stage of their life cycle, the heterogeneity in members shows up particularly in the capital share hold in the cooperatives. The categorization into core members and common 
members is the most obvious result of divergences among the members. The differences may cause conflicts of interest among members, resulting in farmers doubting whether or not to continue participating in the cooperative.

Though both Chinese and Western cooperatives have similar internal governance structures, the background of the current status of the internal structures is different. The innovation of internal governance in EU cooperatives was driven by the need to attract outside risk capital and to strengthen the position of professional managers. The current internal structure of Chinese cooperatives is more the result of the implementation of cooperative law, which allows a differentiation between core and common members. From the perspective of the principles of effective collective action developed by Ostrom (1990), the internal governance of Chinese cooperatives entails certain risks for their future development. Particularly the principle that sustainable collective action requires effective monitoring by monitors who are part of or who are accountable to the membership seems to be violated.

Finally, the topic of the relationship between cooperatives and the government is different in China compared to Europe. Government support has been playing an indispensable role in the formation and development of cooperatives in China. In Europe, various policies exist to support the development of policies. These policies, however, do not interfere with the internal governance and internal operations of cooperatives. The Chinese government has been crucial for the genesis of cooperatives after 2007, and government support has been instrumental in the establishment of a large number of new cooperatives. However, abundant government support has also lead to the establishment of fake cooperatives.

Through a comparative literature review on Western European and Chinese cooperatives, several knowledge gaps on Chinese cooperatives have become apparent. One of the important topics for further research is the role of cooperatives in value chains, particularly their contribution to improving food quality and food safety (Royer et al., 2016). The structural changes in the agro-food markets, such as concerns about food safety, quality and socio-economic and environmental conditions of production, calls for better coordination of the sequential activities in the value chain (Bijman et al., 2011). These changes are also happening in transition countries like China and in developing countries (Swinnen and Maertens, 2007). In these circumstances, smallholders become increasingly vulnerable to exploitation, and cooperatives are becoming more important for these farmers to increase their bargaining power (Clegg, 2006; Ito et al., 2012). 
Another knowledge gap relates to the internal governance structure of agricultural cooperatives in China and its effect on the relationship between members and cooperative and the impact on members' trust and commitment to the cooperative. Though many economists have contributed to analyzing the current status of Chinese cooperatives, most of the research is based on qualitative analysis, lacking solid empirical ground. Therefore, it would be useful to explore these questions through quantitative research in order to generate stronger evidence. 


\section{References}

Bhuyan, S., Leistritz, F. L., 2001. An examination of characteristics and determinants of success of cooperatives in the non-agricultural sectors, Journal of Cooperatives. 16, 45-62.

Bijman, J., 2016. The changing nature of farmer collective action: Introduction to the book, in J. Bijman, R. Muradian and J. Schuurman eds., Cooperatives, Economic Democratization and Rural Development. Edward Elgar Publishing Ltd., Cheltenham, UK.

Bijman, J., Hanisch, M., Sangen, G., 2014. Shifting control? The changes of internal governance in agricultural cooperatives in the EU, Annals of Public and Cooperative Economics. 85, 641-661.

Bijman, J., Hendrikse, G., Oijen, A., 2013. Accommodating two worlds in one organisation: changing board models in agricultural cooperatives, Managerial and Decision Economics. 34, 204-217.

Bijman, J., Iliopoulos, C., 2014. Farmers' cooperatives in the EU: Policies, strategies, and organization, Annals of Public and Cooperative Economics. 85, 497-508.

Bijman, J., Muradian, R., Cechin, A., 2011. Agricultural cooperatives and value chain coordination, in A. H. J. Helmsing and S. Vellema eds., Value Chains, Social Inclusion and Economic Development: Contrasting Theories and Realities. Routledge, Abingdon, Oxon.

Bono, P., 2012. Support for Farmers' Cooperatives: Country Report Italy. Wageningen UR.

Brusselaers, J., Poppe, K., Azcarate, T. G., 2014. Do policy measures impact the position and performance of farmers'cooperaitves in the EU? , Annals of Public and Cooperative Economics. 85, 531-553.

Chaddad, F., Iliopoulos, C., 2013. Control Rights, Governance, and the Costs of Ownership in Agricultural Cooperatives, Agribusiness. 29, 3-22.

Chaddad, F. R., Cook, M. L., 2004. Understanding new cooperative models: an ownership-control rights typology, Applied Economic Perspectives and Policy. 26, 348-360.

Chloupkova, J., 2002. European cooperative movement: background and common denominators, Royal Veterinary and Agricultural University,Department of Economics and Natural Resources, Unit of Economics. Working Paper (Denmark), 1-46.

Clegg, J., 2006. Rural cooperatives in china: Policy and practice, Journal of Small Business and Enterprise Development. 13, 219-234.

COGECA, 2015. Development of agricultural cooperatives in the EU 2014. Available at http://zadruge.coop/upload_data/site_files/development-of-agricultural-cooperatives-in-theeu_2014.pdf.

Cook, M. L., 1995. The future of US agricultural cooperatives: A neo-institutional approach, American Journal of Agricultural Economics. 77, 1153-1159.

Cook, M. L., Iliopoulos, C., 1999. Beginning to Inform the Theory of the Cooperative Firm: Emergence of the New Generation Cooperative, LTA. 4, 525-535.

Cui, B., Xie, Y., 2014. Farmer special cooperatives: "double control" mechanism and its effects on the cooperative Issues in Agricultural Economy, 60-67. (in Chinese)

Dedieu, M.-S., Courleux, F., 2011. Agricultural cooperatives: the reference in term of farmer economic organisation, in A. Ministry of Agriculture, and Forestry ed. Centre for studies and strategic foresight, Montreuil, France.

Deng, H., Huang, J., Xu, Z., Rozelle, S., 2010. Policy support and emerging farmer professional cooperatives in rural China, China Economic Review. 21, 495-507.

Deng, H., Wang, W., 2014. The nature of cooperatives and testing in reality - is there real farmer cooperatives in China, China Rural Economy, 15-26. (in Chinese)

Dunn, J. R., 1988. Basic cooperative principles and their relationship to selected practices, Journal of Agricultural Cooperation. 3, 83-93.

Fairbairn, B., 2004. History of Cooperatives, in C. D. Merrett and N. Walzer eds., Cooperatives and Local Development: Theory and Applications for the 21st Century. M.E. Sharpe, New York.

Fernández, E., 2014. Selling agricultural products: farmers' co-operatives in production and marketing, 18801930, Business History. 56, 547-568.

Fici, A., 2013. An introduction to cooperative law, in D. Cracogna, A. Fici and H. Henrÿ eds., International Handbook of Cooperative Law. Springer, Heidelberg.

Fock, A., Zachernuk, T., 2006. China - Farmers professional associations: Review and policy recommendations (English). EASRD working paper series. Washington, DC: World Bank.

http://documents.worldbank.org/curated/en/539401468218987959/China-Farmers-professionalassociations-review-and-policy-recommendations

Gutierez, C., Atela, T. R., Dueñas, D. M., 2005. A comparative synthesis of 20th century agricultural cooperative movements in Europe, J. Rural Cooper. 33, 47-65.

Hansmann, H., 1999. Cooperative firms in theory and practice, Finish Journal of Business Economics, 387-403. Hind, A. M., 1999. Co-operative life cycle and goals, Journal of Agricultural Economics. 50, 536-548. 
Huang, J., Rozelle, S., 2015. The Role of Agriculture in China's Development: Performance, Determinants of Successes and Future Challenges, in P. Shome and P. Sharma eds., Emerging Economies. Springer, New Delhi, India.

Huang, Z., Shao, K., 2009. The evolustion of the nature of cooperative Journal of Zhengjiang University 39, 1116. (in Chinese)

Huang, Z., Shao, K., Xu, X., 2010. Experience and Inspiration from Taiwan Farmers cooperatives and the future of development direction of Farmer Cooperative Organizations in Mainland, Taiwan Studies, 43-48. (in Chinese)

Iliopoulos, C., Hendrikse, G., 2009. Influence costs in agribusiness cooperatives: evidence from case studies, International Studies of Management \& Organization. 39, 60-80.

Ito, J., Bao, Z. S., Su, Q., 2012. Distributional effects of agricultural cooperatives in China: Exclusion of smallholders and potential gains on participation, Food Policy. 37, 700-709.

Kaarlehto, P., 1955. Cooperation as a form of economic integration, Acta Agriculturae Scandinavica. 5, 85-97.

Kalmi, P., 2007. The disappearance of cooperatives from economics textbooks, Cambridge Journal of Economics. 31, 625-647.

Kalogeras, N., Pennings, J. M., van der Lans, I., Garcia, P., van Dijk, G., 2009. Understanding heterogeneous preferences of cooperative members, Agribusiness. 25, 90-111.

Karantininis, K., Zago, A., 2001. Endogenous membership in mixed duopsonies, American Journal of Agricultural Economics, 1266-1272.

Liang, Q., Hendrikse, G., 2013. Core and common members in the genesis of farmer cooperatives in China, Managerial and Decision Economics. 34, 244-257.

Liang, Q., Hendrikse, G., Huang, Z., Xu, X., 2015. Governance Structure of Chinese Farmer Cooperatives: Evidence From Zhejiang Province, Agribusiness. 31, 198-214.

Lin, J., Huang, S., 2007. Analysis on membership heterogeneity and cooperative ownership, Issues in Agricultural Economy, 12-17. (in Chinese)

Lin, J. Y., 1990. Collectivization and China's Agricultural Crisis in 1959-1961, Journal of Political Economy. 98, 1228-1252.

Ma, Y., 2013. Identifying and assessing of Chinese Cooperatives, China Rural Survey, 65-71. (in Chinese)

Ma, Y., Meng, C., 2008. Double Principal-Agency in farmer cooperatives-problems and improvement ideas, Issues in Agricultural Economy, 55-60. (in Chinese)

McMaster, M. D., 1996. The intelligence advantage organising for complexity. Butterworth-Heinemann, Oxford.

Milgrom, P., Roberts, J., 1990. Bargaining costs, influence costs, and the organization of economic activity, Perspectives on positive political economy. 57, 60.

Mooney, P. H., 2004. Democratizing rural Economy: institutional friction, sustainable struggle and the cooperative movement*, Rural Sociology. 69, 76-98.

Ohm, H., 1956. Member behavior and optimal pricing in marketing cooperatives, Journal of Farm Economics, 613-621.

Osterberg, P., Nilsson, J., 2009. Members' Perception of Their Participation in the Governance of Cooperatives: The Key to Trust and Commitment in Agricultural Cooperatives, Agribusiness. 25, 181-197.

Ostrom, E., 1990. Governing the commons: The evolution of institutions for collective action. Cambridge university press.

Pan, J., 2011. Specialized Farmers' Cooperatives in China: The Interpretation of the Data of their Development, China Rural Survey. 6, 2-11. (in Chinese)

Peng, Y., Yuan, P., 2014. Empirical Research on the relationship between entrepreneurship of cooperative chairman and cooperative performance, Rural Economy. 12, 023.

Pyykkönen, P., Bäckman, S., Kauriinoja, H., 2012. Support for Farmers' Cooperatives: Country Report Denmark, available.

Rebelo, J., Caldas, J. V., Matulich, S. C., 2008. Manager power, member behavior and capital structure: Portuguese Douro wine cooperatives", Agricultural economic review.

Richards, T. J., Manfredo, M. R., 2003. Cooperative mergers and acquisitions: the role of capital constraints, Journal of agricultural and resource economics, 152-168.

Royer, A., Bijman, J., Bitzer, V., 2016. Linking smallholder farmers to high quality food chains: Appraising institutional arrangements, in J. Bijman and V. Bitzer eds., Quality and innovation in food chains: Lessons and insights from Africa. Wageningen Academic Publishers, Wageningen, NL.

SAIC, 2015. National report on the development of market players in 2014, available.

Sun, Y., 2003. Cultural Analysis of cooperative organizations, Agricultural Economics. 1, 11-13.

Sun, Y., 2014. Research on the member trust in the cooperative--based on the survey of swine industry in Hunan, Issues in Agricultural Economy, 68-75. (in Chinese) 
Swinnen, J. F., Maertens, M., 2007. Globalization, privatization, and vertical coordination in food value chains in developing and transition countries, Agricultural economics. 37, 89-102.

Valentinov, V., Iliopoulos, C., 2013. Economic Theories of Nonprofits and Agricultural Cooperatives Compared: New Perspectives for Nonprofit Scholars, Nonprofit and Voluntary Sector Quarterly. 42, 109-126.

Wang, W., Dong, S., 2009. The formation of and reasons for the financing difficulties in the cooperatives Rural Economy, 75-77. (in Chinese)

Wen, T., 2009. Department and capital flowing to the rurual area and the development of farmer cooperatives, Economic Theory and Mangement. 7, 5-12. (in Chinese)

Wen, T., 2013. The predicament and solutions of the development of farmers' professional cooperatives, Journal of Hunan Agricultural University (social science). 14, 4-6. (in Chinese)

$\mathrm{Xu}, \mathrm{X} ., 2012$. Analysis of Farmer Specialized Cooperatives: A Domestic Literature-based Discussion, China Rural Survey, 2-12. (in Chinese)

Yu, K., Zhu, X., Chen, X., 2015. Transaction costs and performance variation of agricultural operators, China Agricultural Economic Review. 7, 374-388. (in Chinese)

Yuan, P., 2013. Explorative analysis on the four modes of agri-industrilization involving firms, cooperatives and farmer households, Chinese Rural Economy, 38-44. (in Chinese)

Yuan, Y., Gao, P., 2012. Farmers' Financial Choices and Informal Credit Markets in China, China Agricultural Economic Review. 4, 216-232.

Zhang, X., 2009. The cooperatives run by big farmers and leading companies are the realistic choices for the development of Chinese cooperatives, China Co-operative Economy, 45-45. (in Chinese)

Zhang, Y., Huang, Z., 2014. Identifying risks inherent in farmer cooperatives in China, China Agricultural Economic Review. 6, 335-354.

Zheng, S., Wang, Z., Awokuse, T. O., 2012. Determinants of producers' participation in agricultural cooperatives: evidence from Northern China, Applied Economic Perspectives and Policy. 34, 167-186.

Zheng, S., Wang, Z. G., Song, S. F., 2011. Farmers' behaviors and performance in cooperatives in Jilin Province of China: A case study, Social Science Journal. 48, 449-457. 


\title{
3. Cooperative membership and farmers' choice of marketing channels: Evidence from apple farmers in Shaanxi and Shandong Provinces, China ${ }^{1}$
}

\begin{abstract}
Cooperatives are established to improve farmers' production conditions, to increase their bargaining power and to enable them to benefit from modern value chains. In China, farmers are members of a cooperative for multiple reasons. Little is known on whether and how cooperative membership affects farmers' choice of marketing channels. This paper examines determinants of farmers' choice of marketing channels, especially how cooperative membership impacts upon this choice. Our analysis is based on survey data collected in 2015 among 625 apple growing farm households in the provinces Shaanxi and Shandong. We employ endogenous switching probit models to deal with potential endogeneity of membership in estimating the determinants of marketing channel choices. We find that cooperative membership has a positive impact on selling to wholesalers and a negative impact on selling to small dealers, but no significant impact on selling to the cooperative itself. As products sold through cooperatives generally comply with relatively stringent food quality and safety standards, these results imply that policies promoting cooperative members to sell their products through cooperatives are likely to have a significant impact on food quality and food safety in China.
\end{abstract}

\section{Keywords}

Cooperative membership, marketing channels, endogenous switching probit model, China

\footnotetext{
${ }^{1}$ Revised based on the paper by Jinghui Hao, Jos Bijman, Cornelis Gardebroek, Nico Heerink, Wim Heijman, Xuexi Huo, published in Food Policy, 2018 (74), pp. 53-64. https://doi.org/10.1016/j.foodpol.2017.11.004
} 


\subsection{Introduction}

Recent structural changes in agro-food markets are characterised by increasing public concern about food quality and food safety in both developed and developing countries. Demand for better quality food and for stricter safety standards is growing, mainly due to the increasing purchasing power of consumers (Narrod, et al., 2009). These changes can be both opportunities and challenges to smallholder farmers. On the one hand, the changes allow farmers to benefit from opportunities arising from export markets, local supermarkets and new processing firms (Bijman, 2016). On the other hand, these new markets in turn require compliance with higher production and food safety standards and the stronger coordination of sequential activities in the value chain (Abebe, et al., 2013). The high costs of compliance with these standards can exclude smallholder farmers from these new markets.

Cooperatives can facilitate smallholder farmers to access markets and strengthen their economic position. Firstly, cooperatives enable farmers to bargain collectively with both sellers of inputs and buyers of farm products (Bijman and Iliopoulos, 2014). Secondly, cooperatives can support the information flow between farmers and the market and thus help farmers to meet the specific requirements of high-value added food markets (Wollni and Zeller, 2007). In addition, cooperatives can help realise food traceability (Moustier, et al., 2010), thereby contributing to food safety.

The Chinese land tenure reform in the late 1970s turned the farm household into the basic unit of agricultural production. The land reform provided most farmers with an adequate basis for their livelihoods. However, the reform also resulted in land fragmentation and small-scale agriculture, which have become an obstacle to develop modern agriculture (Tan, et al., 2008). Like smallholder farmers in other developing countries, Chinese farmers often have difficulties in accessing high-value agricultural markets. Having realised that cooperatives can facilitate smallholders to meet market requirements, the Chinese government began promoting the development of cooperatives at the beginning of the $21^{\text {st }}$ century (Jia, et al., 2012b). The promulgation of the Chinese law on Specialised Farmers Cooperatives in 2006 has been a milestone in the development of Chinese cooperatives. By 
October 2015, over $40 \%$ of farm households had become members of at least one cooperative. ${ }^{1}$

Research on agricultural cooperatives has focussed on two main issues. One issue is the relationship between the cooperative and its members, such as the determinants of cooperative membership (La Ferrara, 2002, Fischer and Qaim, 2012), the relationship between farmers' preferences and the functions of the cooperative (Kalogeras, et al., 2009, Cechin, et al., 2013), and the effect of cooperatives on farmers' market participation (Barrett, 2008, Hellin, et al., 2009). The other issue is the impact of cooperatives on agricultural production, the adoption of agricultural technology, and farmers' welfare (Abebaw and Haile, 2013, Chagwiza, et al., 2016) .

Limited literature is available on whether or not, and to what extent, the development of cooperatives affects farmers' choice of marketing channels. Mujawamariya, et al. (2013), Milford (2014) analyse the reasons for producers' choice of different marketing outlets by comparing production costs and transaction costs involved in dealing with different buyers with different production requirements, respectively. Both studies do not examine the impact of cooperative membership on the choice of marketing channels. Jia, et al. (2012b) analyse the main marketing channels of cooperatives in China and find that cooperatives mainly sell products to wholesale markets and facilitate farmers' access to markets by bridging farmers and government-driven agribusiness. Since they use the cooperative as the unit of analysis, they do not examine farmers' motivations for joining cooperatives, nor the impact of membership on farmers' choice of marketing channel. Insights into such choices by farmers are important to evaluate recent policies in China that aim at stimulating farmers' involvement in high-value food chains through promoting their participation in cooperatives. The objective of this paper is therefore to examine the determinants of cooperative membership for farmers and the effect of membership and other factors on farmers' choices of marketing channels.

We focus our analysis on apple farmers in the two main apple producing areas in China. China is the world's leading producer of apples, producing roughly $55 \%$ of the total apple output in 2015 (Frederick, et al., 2015). Apples are the fruit crop with the largest acreage and

\footnotetext{
1 Translated by authors from the news report entitled " 1.47 million cooperatives including $40 \%$ of farm households nationwide". The original text is written in Chinese and was released on January 1, 2016; it can be found at: http://politics.people.com.cn/n1/2016/0111/c1001-28035566.html.
} 
the highest production value in China, and have been the dominant income source for farmers in the two main apple production regions - the Bohai Gulf area and the Loess Plateau area (Wang and Huo, 2014). The empirical analysis is based on an extensive field survey of 625 apple farm households in Shaanxi Province located in the Loess Plateau and Shandong Province in the Bohai Gulf. We employ an endogenous switching probit model to estimate the determinants of each marketing channel taking into account the potential endogeneity of the membership decision.

\subsection{Theoretical Framework}

Arguments for the existence of cooperatives can be found both in neoclassical economics and in transaction cost economics. Sexton (1990) posits the competitive yardstick effect of cooperatives, which means that cooperatives have a competition enhancing effect in oligopolistic markets. It was found that the degree of yardstick effect is determined by membership, market structure and the resulting volume of deliveries (Hoffman and Royer, 1997). However, neoclassical economics provides little insight in how to structure transaction relationships. Transaction cost economics offers a better framework to analyse the transaction attributes and the governance structures (Sykuta and Cook, 2001). In this section we use transaction costs economics to analyse which factors may affect farmers' choices of cooperative membership and marketing channels.

\subsubsection{Transaction cost theory}

Transaction costs arise due to attributes of the transaction as well as characteristics of the human actors involved in the transaction. Williamson (2005) assumes that transaction costs are caused by bounded rationality and opportunism of human behaviour and by the attributes of a transaction, especially its uncertainty, frequency ${ }^{1}$ and asset specificity (Williamson, 1979). The choice of cooperatives as an institutional arrangement results from high levels of asset specificity and transaction uncertainties (Ménard, 2007). Transactions between farmers and buyers are closely related to farmers' assets for production and their geographical location (Key, et al. (2000). For example, due to the small size of the farm, economies of

\footnotetext{
1 In our empirical analysis we use cross-section data on marketing channels used by apples producers in the year 2014. We therefore disregard transaction frequencies in the remainder of this paper.
} 
scale cannot be realised by smallholders; they thus face higher external transaction costs in obtaining inputs and financial services.

\subsubsection{Production-specific assets}

We define production-specific assets as both physical and human investments that are specialised and unique to a product. Physical production asset specificity consists of investments in land, machinery, buildings and is closely related to the specialisation of the farm. Human asset specificity arises from "learning by doing" (Williamson, 1998). Skill acquisition requires time, energy and money. Acquired skills, especially job-specific skills, are not easy to transfer across jobs. Human asset specificity in this sense is a sunk cost, which leads to a high probability of being locked in.

\subsubsection{Geographical location}

Geographical conditions limit the size and distribution of farms. Small farms usually face high transaction costs because economies of scale in transacting cannot be realised. Smallholders have higher unit costs of procuring inputs, obtaining credit and other financial services, getting agronomic and market information, and marketing products (Wiggins, et al., 2010). In addition, adverse geography generally co-occurs with poor roads, leading to high transportation costs.

\subsubsection{Transaction uncertainty}

Transactions are subject to both behavioural and environmental uncertainty. Behavioural uncertainty comes from opportunistic inclinations of the transacting parties (John and Weitz, 1988), while environmental uncertainty results from the inability to specify the exact conditions of the future exchange. Uncertainties contribute to transaction costs. Direct ex ante transaction costs arising from behavioural uncertainty and information asymmetry include the costs of screening and selecting partners. Direct ex post transaction costs are related to the processes put in place to measure a partner's performance (Standifird and Marshall, 2000).

\subsubsection{Farmers' choices}

We distinguish between two choices farmers can make. The first choice is about membership of a cooperative, while the second choice is about marketing channel. We assume that farmers make these decisions on the basis of the costs and benefits related to each choice. However, it is impossible to measure all the costs and benefits of both decisions (Masten, et al., 1991). It is particularly difficult to measure accurately the transaction costs associated 
with the marketing process. Transaction costs thus are mainly assessed in a comparative manner (Verhaegen and Van Huylenbroeck, 2001). We adopt the empirical approach proposed by (Williamson, 1991), which means that we focus on the transaction characteristics in order to estimate the determinants of farmers' membership and marketing channel choice.

\subsubsection{Choice of cooperative membership}

Cooperative membership brings both material and immaterial benefits to farmers. Firstly, cooperatives decrease transaction costs and improve transaction efficiency (Royer, 2011). Buyers can offer higher prices for products because of the reduced transaction costs (Swinnen, 2005). Secondly, participating in cooperatives can improve small farmers' access to both input and output markets (Key et al., 2000). In addition, members can benefit from the decision rights over the cooperatives' strategic assets and thus reduce the risk of being locked in or held up (Hendrikse and Bijman, 2002). The immaterial benefits of membership mainly refer to the social interaction with other members, developing both personal social networks and business relationships (Hansen, et al., 2002).

The typical costs of membership include membership fees, time and energy involved in cooperative affairs such as decision-making and monitoring manager performance (Pascucci, et al., 2012b). We assume that farmers decide to participate in a cooperative when the benefits of participation exceed the costs thereof.

\subsubsection{Choice of marketing channel}

A marketing channel refers to a set of interdependent organisations involved in the process of making a product or service available for use or consumption (Palmatier, et al., 2014). We focus on the upstream segment of the marketing channel: the transaction relationship between apple producers and their buyers. In China, the main marketing channels for apple farmers are small dealers, wholesalers and cooperatives. Farmers choose one or more of these channels to sell their products.

We assume that a farmer decides to sell products after evaluating transaction costs and benefits associated with each marketing channel given his/her own production conditions. To a large extent transaction costs and benefits are determined by the characteristics of the marketing channels. 
Small dealers are small and itinerant traders. They visit villages and look for potential sellers. When an agreement is reached between the small dealer and the farmer, the dealer buys the products directly from the farmer. Such transactions are spot deliveries, most of which are carried out either at farm gate or storage location. Grading and packaging work is usually done by the farmers themselves.

Compared with small dealers, wholesalers usually have a larger scale of business. Instead of buying products directly from farmers, they usually employ local villagers as brokers to contact with potential sellers. Most wholesalers will choose a convenient location in the village where all the potential sellers bring their products. Wholesalers employ workers to do grading and primary packaging.

Cooperatives are relatively new actors in marketing channels. Cooperative membership does not necessarily mean choosing the cooperative as the marketing channel. Not all members deliver their products to the cooperative, while non-member farmers can also sell the products to the cooperative.

Other channels mainly consist of juice processors and selling within personal social networks. Farmers usually sell degraded apples to juice processors.

The conceptual framework presented above is depicted schematically in Figure 3.1.

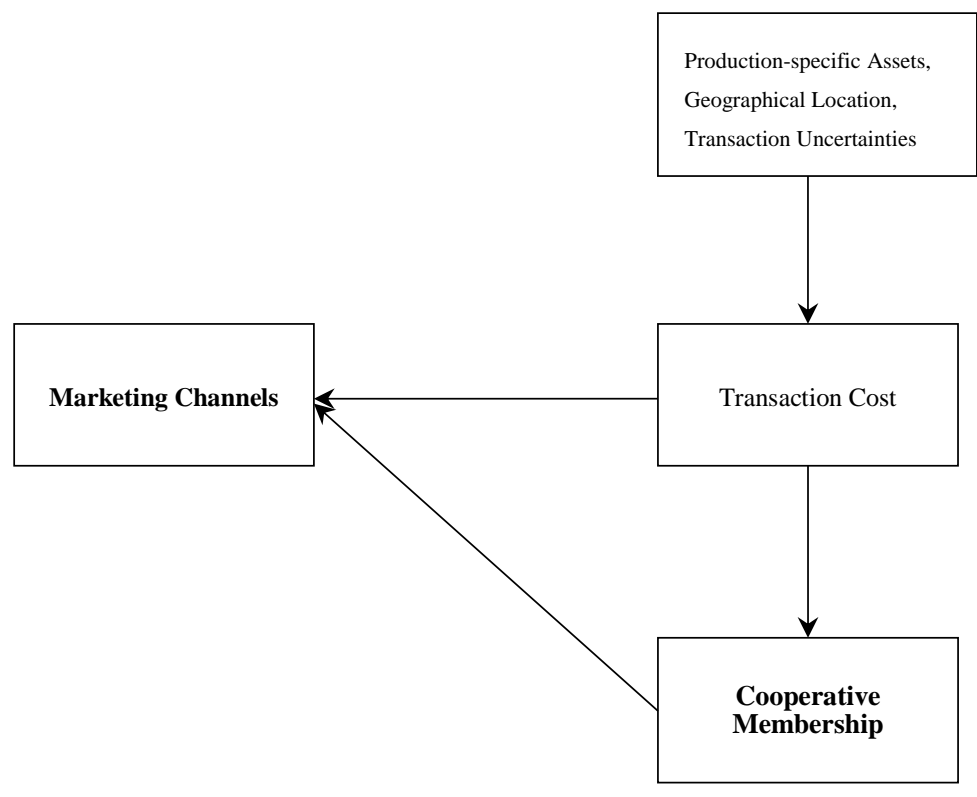

Figure 3.1 Conceptual Framework 


\subsection{Model specification}

When we evaluate the effect of cooperative membership on farmers' choice of marketing channels, we cannot ignore the potential endogeneity of membership. Farmers may self-select into cooperatives because of unobserved factors such as incentives and ability. These same unobservables may also influence the choice of marketing channel. For example, a farmer may choose to become a cooperative member with the intention to benefit from the possibility of selling outputs through a certain marketing channel. In such cases, the error terms of the membership model and the marketing channel model will be correlated, and membership will be endogenous in the marketing choice equation. Neglecting or failing to account for endogeneity of cooperative membership will result in inconsistent estimates and lead to spurious conclusions (Heckman, 1978).

Instrumental variable (IV) estimation and control function approaches are two common methods to deal with endogeneity of strictly continuous outcome variables (Heckman, 1978, Wooldridge, 2014). However, addressing the problem of endogeneity in limited dependent variable models is complicated by the fact that a nonlinear model is applied to fit the data, which invalidates a simple IV procedure (Wooldridge, 2010). For binary outcomes a simple alternative strategy is to use a Linear Probability Model (LPM) and two-stage least squares (2SLS) to instrument the endogenous binary regressor (Angrist, 2001). However, the LPM has many known problems such as predictions outside the $[0,1]$ interval and constant marginal effects. Moreover, a 2SLS approach is less efficient than a full information maximum likelihood (FIML) approach that is used in the method applied in this study.

An alternative approach is to estimate a bivariate probit regression with a recursive structure, viz. one of the outcomes is an endogenous regressor in the other equation. E.g. the cooperative membership decision is a covariate in the marketing channel decision equation but not vice versa. Greene (2008) shows that by using FIML one can ignore the endogenous nature of the binary regressor and proceed as if there were no endogeneity problem. For an application of this approach see e.g. (Pascucci, et al., 2012a).

In this study we use a related though slightly different approach, the endogenous switching probit model (Miranda and Rabe-Hesketh, 2006). Like the recursive bivariate probit, this model jointly estimates two binary equations, one for cooperative membership and one for marketing channel with the membership dummy included as a covariate in the latter. The endogenous switching probit differs from the recursive bivariate probit in that it explicitly models the dependence between the residuals of the switch equation (cooperative membership) and the outcome equation (choice of marketing channel) via shared random effects, thus mimicking the selection problem described above. The bivariate probit model only considers the correlation between residuals of both equations, without explicitly modelling why these residuals are related. The shared random effect in the endogenous 
switching probit reflects unobservables related to both cooperative membership and choice of marketing channel.

Building on Pascucci, et al. (2012a), we specify the membership equation $\left(\mathrm{C}_{\mathrm{i}}^{*}\right)$ and the marketing channel choice model $\left(\mathrm{M}_{\mathrm{ij}}{ }^{*}\right)$ as:

$\mathrm{C}_{\mathrm{i}}^{*}=\alpha \mathrm{X}_{\mathrm{i}}+\mathrm{u}_{\mathrm{i}}, \quad \mathrm{C}_{\mathrm{i}}=1$ if $\mathrm{C}_{\mathrm{i}}^{*}>0, \mathrm{C}_{\mathrm{i}}=0$ otherwise

$\mathrm{M}_{\mathrm{ij}}{ }^{*}=\beta \mathrm{Y}_{\mathrm{i}}+\gamma \mathrm{C}_{\mathrm{i}}^{*}+\mathrm{v}_{\mathrm{i}}, \quad \mathrm{M}_{\mathrm{ij}}=1$ if $\mathrm{M}_{\mathrm{ij}}{ }^{*}>0, \mathrm{M}_{\mathrm{ij}}{ }^{*}=0$ otherwise

Where $X_{i}$ represents a vector of explanatory variables of cooperative membership, $Y_{i}$ represents a vector of explanatory variables of marketing channel choices, $\alpha, \beta$ and $\gamma$ are coefficients to be estimated, and $u_{i}$ and $v_{i}$ are residual terms. To model the potential endogeneity of cooperative membership, we use a shared random effect $\varepsilon_{\mathrm{i}}$ that reflects the dependence between $u_{i}$ and $v_{i}$ (Miranda and Rabe-Hesketh, 2006),

$\mathrm{u}_{\mathrm{i}}=\lambda \varepsilon_{\mathrm{i}}+\zeta_{\mathrm{i}}$

$\mathrm{v}_{\mathrm{i}}=\varepsilon_{\mathrm{i}}+\delta_{\mathrm{i}}$

Here $\varepsilon_{\mathrm{i}}, \zeta_{\mathrm{i}}$, and $\delta_{\mathrm{i}}$ are independently and identically distributed, with mean 0 and variance 1 ; $\lambda$ is a factor loading.

We can derive the correlation $\rho$ between $\mathrm{u}_{\mathrm{i}}$ and $\mathrm{v}_{\mathrm{i}}$ as $\rho=\frac{\lambda}{\sqrt{2\left(\lambda^{2}+1\right)}}$. If $\rho$ equals $0, \mathrm{C}_{\mathrm{i}}^{*}$ will be exogenous in the marketing choice equation and consistent estimates of $\beta$ and $\gamma$ can be obtained by fitting ordinary probit models. If $\rho$ is significantly different from $0, \mathrm{C}_{\mathrm{i}}^{*}$ is endogenous and thus an endogenous switching model will be employed.

\subsection{Farm survey}

We conducted a farm households and cooperatives survey between January and March, $2015^{1}$ in Shaanxi Province in the Loess Plateau region and Shandong Province in the Bohai Gulf region. A multistage sampling procedure was used for the selection of observation units. In the first stage, we used the probability proportional to size (PPS) method to select 7 counties (out of the 10 most important apple production counties) in Shaanxi and 8 counties (out of the

\footnotetext{
${ }^{1}$ Because of the Chinese spring festival in February, our survey was conducted in two periods, before and after the spring festival.
} 
10 most important apple production counties) in Shandong according to the size of apple production in 2014. In the second stage, we asked the Agricultural Bureau in each county for the list of apple cooperatives in the county ${ }^{1} ; 5$ cooperatives were randomly selected from those lists. Therefore, in total we first selected 75 cooperatives. However, the chairmen of 12 out of the 75 selected cooperatives could not be reached. Therefore, we dropped these 12 cooperatives from our sample resulting in a final sample of 63 cooperatives that were interviewed (30 in Shaanxi and 33 in Shandong). We did face-to-face interviews with the chairperson or other officials involved in cooperative management ${ }^{2}$. Data about the cooperative (e.g. number of members, initiation) were also collected.

Next, 10 - 12 farm households were interviewed in the village where the cooperative is located $^{3}$. At least 6 cooperative members in each village were interviewed. This gave a total number of 700 farm households that were interviewed, composed of 429 member farm households and 271 non-member households. Using a structured questionnaire, information was collected on apple production in 2009 and 2014 and apple marketing in 2014 (including input use, costs, yields, and output price), as well as household and farm characteristics (e.g. age, education, farm size, and asset investments), and farmers' perceptions about transactions. The collected information was based as much as possible on written records; for farmers that did not keep records it was based on recall data. Some of the interviewed farmers had not sold the apples harvested in 2014, but kept these apples in cold storage. We excluded these farmers from our analysis. Finally, data from 625 farmers, including 374 member farmers (184 in Shaanxi and 190 in Shandong) and 251 non-member farmers (110 in Shaanxi and 141 in Shandong) have been used in the empirical analysis.

\footnotetext{
${ }^{1}$ We did not register the number of cooperatives that were on each list. For the sake of confidentiality, the local agricultural bureaus did not allow us to take the name lists of cooperatives out of their offices.

${ }^{2}$ In two cases, the cooperative chairmen were out of office for business during our survey time. We had no choice but to interview others involved in the cooperative management. Both of them knew their chairmen well and could pass on basic information about the chairmen, such as age, education level, and work experience.

${ }^{3}$ One team had five enumerators, the other team had ten enumerators. The enumerators went in different directions from the local village offices and interviewed the first one or two farm households that were found at home.
} 


\subsection{Variable specifications and expected effects}

Table 3.1 shows the variables used to explain farmers' decision on cooperative membership and choice of marketing channels. Their choice is based on the conceptual framework in Section 2. 
Table 3.1 Expected effects

\begin{tabular}{|c|c|c|c|c|c|}
\hline Hypothesis & & $\begin{array}{l}\text { Variable } \\
\text { name }\end{array}$ & $\begin{array}{l}\text { Impact } \\
\text { on TC }\end{array}$ & $\begin{array}{l}\text { Impact on } \\
\text { membership }\end{array}$ & Description \\
\hline \multirow{5}{*}{$\begin{array}{l}\text { Control } \\
\text { Variables }\end{array}$} & & gender & $+/-$ & $+/-$ & gender of the household head (male $=1$ ) \\
\hline & & quality & $+/-$ & 0 & $\begin{array}{l}\% \text { of the apples without blemishes in the total } \\
\text { apple output in } 2009\end{array}$ \\
\hline & & area & + & + & size of land bearing apples (unit: $m u^{1}$ ) \\
\hline & Physical PA & $\begin{array}{l}\text { non-farm } \\
\text { work }\end{array}$ & - & 0 & $\begin{array}{l}\text { the household head participating in non-farm } \\
\text { work }=1 \text {, otherwise }=0\end{array}$ \\
\hline & & specialization & + & 0 & share of land dedicated to apple production \\
\hline \multirow{6}{*}{$\begin{array}{l}\text { Production- } \\
\text { specific } \\
\text { Assets } \\
\text { (PA) }\end{array}$} & & age & $+/-$ & $+/-$ & age of the household head \\
\hline & & education & - & + & years of education of the household head \\
\hline & Human PA & $\begin{array}{l}\text { household } \\
\text { size }\end{array}$ & $+/-$ & $+/-$ & household size \\
\hline & & training & + & + & $\begin{array}{l}\text { frequency of participation in technical } \\
\text { trainings in } 2009\end{array}$ \\
\hline & & skill level & + & + & $\begin{array}{l}\text { self-evaluated level of apple producing skills } \\
\text { (1=bad; } 2=\text { =mediocre; } 3=\text { good; } 4=\text { =xcellent })\end{array}$ \\
\hline & & plots & + & + & number of plots cultivated by the household \\
\hline \multirow[t]{4}{*}{$\begin{array}{l}\text { Geographical } \\
\text { Location }\end{array}$} & & apple brokers & - & - & $\begin{array}{l}\text { presence of apple brokers in the same village } \\
\text { or nearby villages }=1 \text {, otherwise }=0\end{array}$ \\
\hline & & distance & + & + & $\begin{array}{l}\text { distance to the nearest agricultural spot } \\
\text { market (unit: } \mathrm{km} \text { ) }\end{array}$ \\
\hline & $\begin{array}{c}\text { Environmental } \\
\text { Uncertainty }\end{array}$ & weather loss & + & + & $\begin{array}{l}\text { loss caused by extreme weather in the past } 5 \\
\text { years }=1 \text {, otherwise }=0 \text {. }\end{array}$ \\
\hline & & ex-ante TU1 & + & 0 & $\begin{array}{l}\text { ex-ante TU (To what extent do you agree } \\
\text { with the statement that "I have no idea about } \\
\text { prices to be offered by buyers beforehand?" } \\
\text { Scale 1-5) }\end{array}$ \\
\hline \multirow{3}{*}{$\begin{array}{l}\text { Transaction } \\
\text { Uncertainty } \\
\text { (TU) }\end{array}$} & Behavioural & ex-ante TU2 & - & 0 & $\begin{array}{l}\text { ex-ante TU (To what extent do you agree } \\
\text { with the statement that "I know beforehand } \\
\text { about the quality requirements of buyers?" } \\
\text { Scale 1-5) }\end{array}$ \\
\hline & Uncertainty & during TU & + & 0 & $\begin{array}{l}\text { during TU (To what extent do you agree with } \\
\text { the statement that "I suffered loss caused by } \\
\text { decisions that were changed unilaterally by } \\
\text { buyers during the transaction?"2 Scale 1-5) }\end{array}$ \\
\hline & & ex post $\mathrm{TU}$ & + & 0 & $\begin{array}{l}\text { ex post TU (To what extent do you agree } \\
\text { with the statement that "I suffered loss } \\
\text { caused by delayed payments by buyers?" } \\
\text { Scale } 1-5)\end{array}$ \\
\hline \multirow{3}{*}{$\begin{array}{l}\text { Institutional } \\
\text { Environment }\end{array}$} & & initiation & 0 & + & $\begin{array}{l}\text { cooperative was initiated by village cadres or } \\
\text { another government organisation }=1 \text {, } \\
\text { otherwise }=0\end{array}$ \\
\hline & & village cadre & 0 & + & $\begin{array}{l}\text { any family member has experience as village } \\
\text { cadre }=1 \text {, otherwise }=0\end{array}$ \\
\hline & & region & $+/-$ & $+/-$ & regional dummy (Shaanxi=1; Shandong=0) \\
\hline
\end{tabular}

Note: TC denotes transaction cost.

+ stands for positive impact; - stands for negative impact; +/- stands for unclear direction; 0 stands for no impact.

\footnotetext{
${ }^{1} \mathrm{mu}$ is traditional Chinese unit of area $(1$ hectare $=15 \mathrm{mu})$.

2 The change during the transaction mainly refers to quitting the transaction unilaterally or lowering the promised intentionally by the buyer before the final deal is reached by both parties.
} 
Indicators of production-specific assets are as follows. We use the apples-bearing land area (labelled 'area') to proxy output size and farm scale. To deal with potential endogeneity, we use a five-year lag for this variable. The share of land dedicated to apple production is used to measure the farmer's degree of specialisation. The more specialised the farm is, the more likely the farmer will have specific assets on the farm (Pascucci et al., 2012a). The degree of participation in non-farm work for the household head is included as an indicator of access to cash income. Studies have shown that nonfarm activities can be an important source of cash income for farm households (Reardon, et al., 1994). We expect that farmers have more liquidity, and hence lower transaction costs, with increasing participation in non-farm work.

Human capital increases "the ability to perceive, interpret, and respond to new events in a context of risk" (Schultz, 1982). Farmer's education level, age and household size are used as indicators of human capital. In addition, the frequency of participation in technical training and the self-evaluated level of apple producing skills ${ }^{1}$ are also included.

We use the number of plots each household cultivates, the distance to the nearest wet market ${ }^{2}$, and a dummy variable indicating whether or not there are apple brokers ${ }^{3}$ in the village or nearby to depict geographical location. Farmers in mountainous or hilly areas tend to have small and scattered land holdings (Tan, et al., 2008). Moreover, the distance to the nearest agricultural wet market is used as an indicator of market access. A dummy variable indicating presence of apple brokers in the same village or nearby villages is used to proxy the availability of market information. We hypothesise that farm households with more plots, larger distance to a wet market, and lack of information sources experience higher transaction costs in marketing.

We measure transaction uncertainty (TU) based on farmers' transaction experiences. Questions about farmers' perceptions of transaction uncertainty are grouped into three categories: ex ante uncertainty, uncertainty during the delivery, and ex post uncertainty. Five-level Likert scales are used to measure the degree of uncertainty. To measure physical environmental uncertainty, which affects economic activities and transaction costs, we use an indicator of whether there have been production losses caused by extreme weather in the past 5 years.

We control for the institutional environment. The Chinese government has been crucial in the genesis of cooperatives in China. Particularly since 2007, government support has been an important reason for the foundation of cooperatives (Deng, et al., 2010). We use three dummy variables to sketch the institutional settings: whether the cooperative was initiated by village cadres or by another

\footnotetext{
1 "Self-evaluated level of apple producing skills" might not only capture farming skills but also perceived self-efficacy (Wuepper and Sauer, 2016).

${ }^{2}$ A wet market is a traditional (street) market selling fresh produce and meat (Tracey-White, 1991).

${ }^{3}$ The term of "apple broker" refers to a person who functions as an intermediary between farmers and buyers in searching, contacting and bargaining.
} 
government organisation, whether family members have been village cadres, and a dummy variable reflecting the region in which the household resides. The first two institutional variables are assumed to only affect the farmer's choice of membership, not the choice of marketing channels.

Using exclusion covariates in the switch equation that do not enter the outcome equation is the preferred approach for model identification (Deb and Trivedi, 2006). The three variables that are used as such in our model are the frequency of participating in training for apple production in 2009, whether cooperatives were initiated by village cadres or other government organisations, and whether any family member has experience as village cadre. Technical training in apple production increases the likelihood that farmers specialise in apple production, and therefore join apple cooperatives. The training usually does not include marketing-related training, and therefore is unlikely to have a direct effect on the choice of marketing channels. There are also no a priori reasons to expect that the way in which cooperatives are initiated has a direct effect on farmers' choice of marketing channels. Likewise, cooperative membership is likely to be affected by the presence of one or more family members with village cadre experience. But a direct effect of village cadre experience on marketing channel choice is much less plausible. Furthermore, due to the potential problem of reverse causality between farmer's degree of specialization in apple production and cooperative membership, we exclude the specialization variable from the cooperative membership equation. For the same reason, we also exclude the non-farm work variable from the switch equation.

\subsection{Results}

\subsubsection{Descriptive statistics}

\subsubsection{Marketing channels}

We find that most farm households plant more than one apple cultivar. The most common cultivars are Fuji, Gala, Delicious, and Jonathan. In Shandong, Fuji is the dominant cultivar planted, accounting for $70.2 \%$ of the total planting area and $76.2 \%$ of the total apple output in 2008; in Shaanxi, the plantation area of Fuji apples equals $65 \%$ of the total area and the planting area has been increasing (Cong, 2008). We thus focus our analysis on Fuji apples only.

The main marketing channels for apple farmers are wholesalers, small dealers and cooperatives. As shown in Table 3.2, the share of wholesalers in the marketing channels is 43.7 percent, followed by small dealers (41.9 percent), cooperatives (10.6 percent) and other channels (3.7 percent). Relatively more non-member farmers sell their apples to small dealers and relatively fewer non-member farmers sell their output to cooperatives. Most 
farmers use just one marketing channel; 52 out of 625 farmers (8.3 percent) sell their apples through two marketing channels. To avoid losing relevant information about these households, we use dummy variables for each of the channels used by the farmers in the sample as dependent variables and use three endogenous switching probit models for estimating the determinants of cooperative memberships and the effect of memberships and other factors on farmers' choices of each of the three marketing channels.

Table 3.2 Apple marketing channels used by members and non-members of cooperatives

\begin{tabular}{cccc}
\hline Marketing Channel & Members & Non-members & Total (\%) \\
\hline Wholesalers & $176(44.0 \%)$ & $120(44.8 \%)$ & $296(43.7 \%)$ \\
Small dealers & $156(38.1 \%)$ & $128(47.8 \%)$ & $284(41.9 \%)$ \\
Cooperatives & $59(14.4 \%)$ & $13(4.9 \%)$ & $72(10.6 \%)$ \\
Other channels & $18(4.4 \%)$ & $7(2.6 \%)$ & $25(3.7 \%)$ \\
\hline Total & $409(100 \%)$ & $268(100 \%)$ & $677(100 \%)$ \\
\hline
\end{tabular}

\subsubsection{Descriptive statistics: Cooperative members and non-members}

Table 3.3 shows descriptive statistics (mean and standard deviation) of cooperative membership and the explanatory variables used in the regression analyses as well as their mean differences between member farmers and non-member farmers. We find that, in general, apple farm households are highly specialised with 84 percent of the land dedicated to apples on average, but with dispersed (3.73 plots per household on average) and small production scales (mean apples-bearing land area of $0.55 \mathrm{ha}$ ). As to the differences between the two groups, cooperative members have higher education levels, more plots of land and participate more in technical training for apple production on average than non-members; and their families have more experience as village cadres on average than non-members. In contrast, non-members are more specialised in apple production and have higher apple producing skills on average than members. 


\begin{tabular}{|c|c|c|c|c|}
\hline Variable Name & $\begin{array}{c}\text { Members } \\
\text { Mean (S.D.) }\end{array}$ & $\begin{array}{l}\text { Non-members } \\
\text { Mean (S.D.) }\end{array}$ & Difference & $\begin{array}{l}\text { Full sample } \\
\text { Mean (S.D.) }\end{array}$ \\
\hline membership & $\begin{array}{c}1.00 \\
(0.00)\end{array}$ & $\begin{array}{c}0.00 \\
(0.00)\end{array}$ & 1.00 & $\begin{array}{c}0.60 \\
(0.49)\end{array}$ \\
\hline gender & $\begin{array}{c}0.99 \\
(0.12)\end{array}$ & $\begin{array}{c}0.97 \\
(0.16)\end{array}$ & $0.02^{*}$ & 0.98 \\
\hline quality & $\begin{array}{l}83.38 \\
(17.71)\end{array}$ & $\begin{array}{c}82.69 \\
(17.69)\end{array}$ & 0.69 & $\begin{array}{c}83.1 \\
(17.69)\end{array}$ \\
\hline area & $\begin{array}{c}8.59 \\
(10.85)\end{array}$ & $\begin{array}{c}7.63 \\
(22.06)\end{array}$ & 0.96 & $\begin{array}{c}8.2 \\
(16.3)\end{array}$ \\
\hline non-farm work & $\begin{array}{c}0.10 \\
(0.34)\end{array}$ & $\begin{array}{c}0.13 \\
(0.30)\end{array}$ & -0.03 & $\begin{array}{c}.11 \\
(0.36)\end{array}$ \\
\hline specialisation & $\begin{array}{c}0.83 \\
(0.23)\end{array}$ & $\begin{array}{c}0.85 \\
(0.23)\end{array}$ & $-0.02^{* *}$ & $\begin{array}{c}0.84 \\
(0.23)\end{array}$ \\
\hline age & $\begin{array}{l}51.99 \\
(7.99)\end{array}$ & $\begin{array}{l}52.05 \\
(9.66)\end{array}$ & -0.06 & $\begin{array}{l}52.01 \\
(8.69)\end{array}$ \\
\hline education & $\begin{array}{c}9.47 \\
(2.27)\end{array}$ & $\begin{array}{c}8.88 \\
(2.52)\end{array}$ & $0.59^{* * *}$ & $\begin{array}{c}9.23 \\
(2.39)\end{array}$ \\
\hline household size & $\begin{array}{l}3.75 \\
(1.37)\end{array}$ & $\begin{array}{c}3.64 \\
(1.49)\end{array}$ & 0.11 & $\begin{array}{c}3.7 \\
(1.42)\end{array}$ \\
\hline training & $\begin{array}{l}2.09 \\
(2.15)\end{array}$ & $\begin{array}{l}1.22 \\
(1.66)\end{array}$ & $0.87^{* * * *}$ & $\begin{array}{l}1.74 \\
(2.01)\end{array}$ \\
\hline skill level & $\begin{array}{c}2.39 \\
(0.69)\end{array}$ & $\begin{array}{c}2.63 \\
(0.72)\end{array}$ & $-0.24^{* * *}$ & $\begin{array}{c}2.53 \\
(0.72)\end{array}$ \\
\hline region & $\begin{array}{c}0.49 \\
(0.50)\end{array}$ & $\begin{array}{l}0.44 \\
(0.5)\end{array}$ & 0.05 & 0.47 \\
\hline plots & $\begin{array}{l}3.86 \\
(2.16)\end{array}$ & $\begin{array}{c}3.55 \\
(1.71)\end{array}$ & $0.31^{* *}$ & $\begin{array}{c}3.73 \\
(1.99)\end{array}$ \\
\hline apple brokers & 0.42 & 0.43 & -0.01 & 0.43 \\
\hline distance & $\begin{array}{c}7.53 \\
(8.50)\end{array}$ & $\begin{array}{c}6.83 \\
(8.32)\end{array}$ & 0.7 & $\begin{array}{c}7.25 \\
(8.43)\end{array}$ \\
\hline weather loss & $\begin{array}{c}0.79 \\
(0.40)\end{array}$ & $\begin{array}{c}0.78 \\
(0.42)\end{array}$ & 0.01 & 0.79 \\
\hline ex ante TU1 & $\begin{array}{c}3.34 \\
(1.38)\end{array}$ & $\begin{array}{c}3.37 \\
(1.37)\end{array}$ & -0.03 & $\begin{array}{c}3.35 \\
(1.37)\end{array}$ \\
\hline ex ante TU2 & $\begin{array}{c}4.22 \\
(1.03)\end{array}$ & $\begin{array}{c}4.18 \\
(1.02)\end{array}$ & 0.04 & $\begin{array}{c}4.21 \\
(1.02)\end{array}$ \\
\hline during TU & $\begin{array}{c}3.02 \\
(1.45)\end{array}$ & $\begin{array}{c}2.88 \\
(1.42)\end{array}$ & 0.14 & $\begin{array}{c}2.96 \\
(1.44)\end{array}$ \\
\hline ex post TU & $\begin{array}{l}2.75 \\
(1.57)\end{array}$ & $\begin{array}{c}2.62 \\
(1.52)\end{array}$ & 0.13 & $\begin{array}{c}2.69 \\
(1.55)\end{array}$ \\
\hline initiation & $\begin{array}{l}0.45 \\
(0.5)\end{array}$ & $\begin{array}{c}0.41 \\
(0.49)\end{array}$ & 0.04 & $\begin{array}{l}0.43 \\
(0.5)\end{array}$ \\
\hline village cadre & $\begin{array}{c}0.27 \\
(0.44) \\
\end{array}$ & $\begin{array}{c}0.16 \\
(0.36) \\
\end{array}$ & $0.11^{* * *}$ & 0.22 \\
\hline Observations & 374 & 251 & -- & 625 \\
\hline
\end{tabular}

Note: S.D. denote standard deviations.

$*^{* * * * *}$, and ${ }^{*}$ denote that mean values for cooperative members are significantly different from non-member farmers at $1 \%$, $5 \%$ and $10 \%$ levels, respectively.

\subsubsection{Estimation results}

We use the endogenous switching probit model (ESP) specified in (1) -(4) to estimate the factors affecting cooperative membership and choice of marketing channels. As shown in Table 3.1, we use 19 explanatory variables to estimate factors affecting farmers' choice of 
membership and 20 explanatory variables for the choice of marketing channels ${ }^{1}$. We focus on the three main marketing channels, i.e. wholesalers, small dealers and cooperatives (see Table 3.2). Due to the small share of apple farmers using other channels (3.7\%; see Table 3.2), we do not distinguish it as a separate channel in the marketing channel choice equations. First, we check the potential multicollinearity of explanatory variables on the basis of variance inflation factors (VIFs) in two separate linear probability models estimated using OLS (Menard, 2002). For the membership equation, the highest VIF is 7.74 (average of 1.87) and for the three delivery equations of each market channel the highest value is 8.16 (average of 1.89$)^{2}$. Both values are lower than the often chosen critical value of 10 (Spanos and McGuirk, 2002), indicating that multicollinearity is not a major problem. Table 3.4 shows the estimation results.

\footnotetext{
${ }^{1}$ Besides the variables listed in Table 3.1, we also include the square term of "area" in the estimations.

${ }^{2}$ If we delete the squared area term in both models, the average values of VIF in the membership model and marketing channel model decrease to 1.18 and 1.17 , respectively.
} 
Table 3.4 Estimation results for endogenous switch probit model of three main marketing channels ${ }^{1}$

\begin{tabular}{|c|c|c|c|c|c|c|c|c|}
\hline \multirow{2}{*}{ Variables } & \multicolumn{2}{|c|}{ Switch Model } & \multicolumn{2}{|c|}{ wholesalers } & \multicolumn{2}{|c|}{ small dealers } & \multicolumn{2}{|c|}{ cooperatives } \\
\hline & Coef. & S.E. & Coef. & S.E. & Coef. & S.E. & Coef. & S.E. \\
\hline membership & -- & -- & $0.961^{* * *}$ & 0.196 & $-1.116^{* * * *}$ & 0.353 & 0.201 & 0.769 \\
\hline gender & 0.367 & 0.389 & 0.166 & 0.378 & -0.190 & 0.383 & -0.052 & 0.539 \\
\hline quality & -- & -- & $0.006^{* *}$ & 0.003 & -0.003 & 0.003 & 0.003 & 0.005 \\
\hline area & $0.040^{* * *}$ & 0.014 & $-0.038^{*}$ & 0.021 & 0.029 & 0.022 & 0.030 & 0.029 \\
\hline$(\text { area })^{2}$ & 0.000 & 0.000 & $0.001^{*}$ & 0.000 & -0.001 & 0.001 & 0.000 & 0.001 \\
\hline non-farm work & -- & -- & $0.236^{*}$ & 0.134 & $-0.311^{* *}$ & 0.160 & 0.092 & 0.235 \\
\hline specialisation & -- & -- & $0.459^{* *}$ & 0.231 & $-0.622^{* * *}$ & 0.246 & 0.589 & 0.378 \\
\hline age & 0.002 & 0.007 & -0.007 & 0.007 & 0.006 & 0.007 & -0.002 & 0.010 \\
\hline education & $0.045^{* *}$ & 0.023 & -0.002 & 0.023 & -0.023 & 0.026 & 0.040 & 0.035 \\
\hline household size & -0.002 & 0.044 & $-0.078^{*}$ & 0.043 & 0.043 & 0.043 & $0.119^{*}$ & 0.063 \\
\hline training & $0.135^{* * *}$ & 0.028 & -- & -- & -- & -- & -- & -- \\
\hline skill level & $0.252^{* * *}$ & 0.077 & -0.044 & 0.077 & -0.018 & 0.088 & 0.126 & 0.118 \\
\hline region & 0.135 & 0.142 & $0.358^{* * *}$ & 0.136 & -0.235 & 0.148 & -0.298 & 0.204 \\
\hline apple brokers & -0.120 & 0.128 & $0.455^{* * *}$ & 0.121 & -0.195 & 0.122 & $-0.707^{* * *}$ & 0.186 \\
\hline plots & $0.052^{*}$ & 0.030 & $0.045^{*}$ & 0.027 & $-0.065^{* *}$ & 0.033 & 0.053 & 0.034 \\
\hline distance & 0.003 & 0.006 & $0.012^{*}$ & 0.006 & $-0.012^{*}$ & 0.007 & 0.006 & 0.009 \\
\hline weather loss & 0.102 & 0.129 & -0.076 & 0.124 & 0.087 & 0.127 & $0.365^{*}$ & 0.198 \\
\hline ex-ante risk1 & -0.028 & 0.040 & 0.018 & 0.037 & 0.033 & 0.039 & -0.076 & 0.054 \\
\hline ex-ante risk2 & 0.021 & 0.052 & 0.012 & 0.049 & 0.015 & 0.050 & -0.104 & 0.068 \\
\hline during-risk & 0.009 & 0.038 & $-0.077^{* *}$ & 0.036 & $0.071^{* *}$ & 0.037 & -0.037 & 0.051 \\
\hline ex-post risk & 0.045 & 0.036 & -0.029 & 0.034 & 0.045 & 0.035 & 0.028 & 0.049 \\
\hline initiation & -0.017 & 0.099 & -- & -- & -- & -- & -- & -- \\
\hline village cadre & $0.232^{*}$ & 0.129 & -- & -- & -- & -- & -- & -- \\
\hline _cons & $-2.219^{* * *}$ & 0.725 & -1.095 & 0.789 & 0.969 & 0.828 & -2.775 & 1.170 \\
\hline$\rho$ & -- & -- & $-0.664^{* * * *}$ & 0.099 & $0.590^{* *}$ & 0.338 & 0.243 & 0.398 \\
\hline no. of obs. & 625 & & 625 & & 625 & & 625 & \\
\hline
\end{tabular}

Note: ${ }^{*},{ }^{* *}$ and ${ }^{* * *}$ denote significance level of $10 \%, 5 \%$ and $1 \%$, respectively.

\footnotetext{
${ }^{1}$ Each marketing channel choice model has one corresponding switch model. Because the estimated coefficients in each switch model have the same signs and similar degrees of significance, we present the results for the switch model of the wholesalers channel for simplicity. Estimation results of the other two switch models are shown in Table A.3.1 in the Appendix.
} 


\subsubsection{Switch model: Cooperative membership}

The second and third column of Table 3.4 present the estimation results for the cooperative membership switch model. We find that the apple bearing area has a significant positive effect on the probability of being a member of a cooperative. As regards the human capital indicators, we find that education of the household head, the frequency of participating in production trainings and the self-evaluated skill level have significant positive effects on cooperative membership. The age of the household head (an indicator of working experience) and household size, on the other hand, do not significantly affect membership decisions. With respect to the indicators of geographic location, only the number of plots owned by the household has a significant impact on membership. We do not find significant effects for the indicators of transaction uncertainty. Finally, only one of the two institutional environment variables is found to have a significant impact on membership decisions. We find that households with family members having experience as village cadre are significantly more likely to participate in a cooperative. It may also be noted that two of three instrumental variables used for identification, frequency of training and experience as village cadre, have a significant effect on membership.

\subsubsection{Outcome model: Choice of marketing channel}

The six columns at the right-hand side of Table 3.4 summarise the estimation results for the three main marketing channels. The values of $\rho$ are significant (at the $1 \%$ and $5 \%$ level, respectively) in the wholesalers and small dealers models. These findings support the premise that the cooperative membership decision is an endogenous decision in the choice of these marketing channels. For the cooperative channel, however, we find that $\rho$ does not significantly differ from zero. Thus membership can be considered exogenous in the case of selling to cooperatives. Therefore, in principle an ordinary probit model could be applied for estimating the factors affecting the choice of this channel. However, note that this result may be due to the relatively small number of farmers selling to cooperatives. Therefore, for congruency we stick to the endogenous switching probit results for all three market outlets.

The most striking result is that for cooperative membership, which is the main focus of our study. We find that membership has a significant positive effect on the probability that an apples farmer will sell the output to a wholesaler, and a significant negative effect on the probability of selling to a small dealer. But membership of a cooperative does not have a statistically significant effect on the probability of selling apples to a cooperative. 
With regard to production-specific assets, we find that land area has a significant non-linear impact on the probability of selling to wholesalers. With an increase in the apples bearing area, farmers seem to be less inclined to sell apples to wholesalers. But when the area exceeds $19 \mathrm{mu}$ (about $1.27 \mathrm{ha}$ ), the probability of selling to wholesalers increases with the area. The positive relationships between apples bearing area and selling to small dealers or cooperatives are both not statistically significant. We further find that more specialized apple farmers and those who are more involved in non-farm work are more likely to sell their output to wholesalers and less likely to sell it to small dealers. The results do not show significant relationships between human capital assets and choice of marketing channels, with one exception. We find that large households are significantly more likely to sell to cooperatives and significantly less likely to sell to wholesalers.

Geographic location seems to play an important role in marketing channel choices. We find that the presence of apple brokers in the village or nearby villages has a significant positive impact on the probability of selling to wholesalers and a significant negative impact on selling to cooperatives. Farmers living in villages with a relatively large distance to the nearest agricultural wet market and farmers with a relatively large number of plots are more likely to sell their output to wholesalers and less likely to sell it to small dealers. Selling to cooperatives is not significantly affected by these two indicators of remoteness. We further find that, controlling for other factors affecting channel choices, farmers in Shandong province are more likely to sell their apples to wholesalers as compared to farmers in Shaanxi province $^{1}$.

The impact of transaction uncertainty on marketing channel choice is limited. We find evidence that farmers who experienced a weather-induced output loss during the previous five years are more likely to sell their apples to cooperatives. Selling to wholesalers or small dealers is not significantly affected by extreme weather losses. Ex ante and ex post transaction uncertainties do not have significant effects on farmers' output channel choices. But uncertainty during a transaction, as caused by unilateral decisions of the buyer, makes apples farmers more likely to sell to small dealers and less likely to sell to wholesalers.

\footnotetext{
${ }^{1}$ It is not possible to replace the province dummy by 14 county dummies in the model, because the cooperatives channel equation can no longer be estimated in that case (given the limited number of households selling through that channel).
} 


\subsection{Discussion}

\subsubsection{Determinants of marketing channel choices}

Our major finding is that cooperative membership has a significantly positive effect on the choice of wholesalers, a negative effect on the choice of small dealers and an insignificant effect on the choice of cooperatives as marketing channel for the apple farmers surveyed for this study. We will discuss this result and its policy implications in more detail in the next chapter.

As regards the other factors affecting marketing channel choices, the land area bearing fruits is found to have a significant negative effect on the probability of selling to wholesalers up to a turning point of almost $19 \mathrm{mu}$ (about $1.27 \mathrm{ha}$.). This finding suggests that very small farmers often sell their apples jointly with other farmers to wholesalers; with increasing land size they are more likely to sell all their output to small dealers or cooperatives. But the estimated coefficients for land area in the equations for the latter two marketing channels do not differ significantly from zero (at a 10 percent level).

With respect to other production-specific assets, we find that farmers who are more involved in non-farm work and those who devote a larger share of their land to apples production are more likely to sell their output to wholesalers and less likely to sell it to small dealers. Transaction costs incurred at the farmers' side may explain the first of these two findings. Farmers involved in non-farm work will face relatively high opportunity costs of the time that they spend on negotiating transactions, obtaining information, and so on. The amount of time spent on output selling transactions will generally be lower for the wholesalers channel, especially when cooperatives coordinate such transactions. The finding that more specialised apples farmers are more likely to sell their output to wholesalers may have to do with the apple quality. More specialised farmers will generally have more knowledge about appropriate production technologies and be able to produce more uniform output. The costs involved in quality checking and grading, which is usually done by the wholesalers themselves, are therefore less.

We do not find evidence that sunk costs of investments in human assets affect the choice of output channels by apples farmers. The only human capital variable that has a statistically significant impact is household size in both the wholesalers and the cooperatives channels equations. It exerts a negative and positive impact (at the 10 percent level) on selling to wholesalers and cooperatives, respectively. The results suggest that larger households may 
have closer contacts with cooperatives and therefore are more likely to sell their output through cooperatives, rather than the other channels. More research is needed to examine the exact underlying mechanism.

The presence of apple brokers in the village or nearby villages has a significant positive impact on the probability of selling to wholesalers and a significant negative impact on selling to cooperatives. Similar to cooperatives, apple brokers usually help organise transactions commissioned by wholesalers, especially in villages without cooperatives. Our findings indicate that apple brokers induce a switch in marketing channels from cooperatives towards wholesalers in villages where cooperatives are present. Other geographical location factors are also found to play important roles. Farmers living in villages with a relatively large distance to the nearest agricultural spot market are more likely to sell their output to wholesalers and less likely to sell it to small dealers. Proximity to a wet market usually means more potential buyers. In particular, there will be more itinerant small dealers with relatively limited travel radius near a wet market. These small dealers prefer to buy apples from sellers nearby to economise on their costs. Similar results are found for the number of plots cultivated by a household. Farm households with a large number of plots usually live in relatively remote, hilly or mountainous areas which are less accessible for small traders. Cooperatives usually buy all grades of their members' apples, even the ones with blemishes caused by extreme weather during the growth period. This fact probably explains why we find that farmers who experienced an output loss during the previous five years are more likely to sell their apples to cooperatives. Ex ante and ex post transaction uncertainties do not have significant effects on farmers' output channel choices. Uncertainty about selling conditions offered to the farmers and negative past payment experiences apparently did not affect marketing channel choices in the survey year. Due to the relatively large transaction volumes, wholesalers usually buy apples from different farmers within the same village and/or nearby villages. They thus can choose among different farmers supplying apples, and usually select farmers who offer apples of comparatively high quality. The significant positive effect of the quality variable in the wholesalers' channel equation is consistent with this observation. Farmers that have not been selected have to take the loss caused by this uncertainty during transactions, and will need to sell to other channels, e.g. small dealers. This explains why we find that uncertainty caused by unilateral decisions of the buyer makes apples farmers more likely to sell to small dealers instead of wholesalers. 


\subsubsection{Determinants of cooperative membership}

The significantly positive effect of land area on cooperative membership is in line with our hypothesis that large-scale farms have more specific assets for apples production. As these assets cannot easily be transferred to other productive purposes, farmers with a larger area of apple bearing land have a greater probability to join cooperatives. Likewise, we find that human asset specificity as reflected by the level of education of the household head, the frequency of technical training and the perceived skill level have significant positive effects on cooperative membership. The only significant indicator of geographic location is plots. Farm households with a larger number of plots usually live in relatively remote, hilly or mountainous. They usually experience higher transaction costs during marketing and thus are more likely to join a cooperative. This result is in line with our expectations. However, we do not find significant effects for the five transaction uncertainty indicators.

Finally, we find that households with one or more family members having experience as a village cadre are significantly more likely to participate in a cooperative. Village cadres in China are supposed to fulfil state tasks (Kung, et al., 2009) and are therefore generally quick responders to new agricultural technologies and techniques and to the new government policies. Given the recent focus in Chinese policy making on the development of cooperatives, it is no surprise that households with village cadre experience are more likely to become members of a cooperative.

\subsubsection{Robustness checks}

As a robustness check, we compare the endogenous switching probit results (Table 3.4) with results from a linear probability model estimated with 2SLS (2SLS-LPM; Table A.3.2 in Appendix) and a bivariate probit model (BPM; Table A.3.3 in Appendix).

Compared with the endogenous switching probit (ESP) estimates, we find that the 2SLS coefficient estimates have similar signs and effects but are less efficient ${ }^{1,2}$. This is also reflected in a smaller number of statistically significant parameters in the 2SLS compared to the ESP. The results of the Durbin-Wu-Hausman test for endogeneity of cooperative

\footnotetext{
${ }^{1}$ Coefficients and standard errors of ESP and 2SLS-LPM are not directly comparable due to different transformations used. Amemiya (1981) suggested to multiply the probit coefficients and standard errors by 0.4 (and add 0.5 for the constant) to make them comparable to LPM parameters.

${ }^{2}$ The three different marketing choice equations can also be estimated together as a system using 3SLS (3SLS-LPM). However, since all three equations contain the same variables theoretically there is no gain in efficiency (Greene, 2008: 257258). This was confirmed when estimating such a system (results available upon request).
} 
membership in the 2SLS are in line with the statistically significant correlation coefficient estimated by the ESP presented in the bottom row of Table 3.4. The main conclusion of our study regarding the impact of cooperative membership on farmers' choice of marketing channels remains the same.

Comparing the results estimated by the BPM and the ESP, we find that the coefficients are very similar both in magnitudes and significance levels. However, generally the ESP produces smaller standard errors than BPM, which gives ESP a comparative advantage. The conclusions that we can draw from the BPM are exactly the same as the ones drawn from the ESP in Section 7.1 above.

\subsection{Conclusions}

This paper seeks to examine how cooperative membership affects farmers' choice of marketing channels, taking into account potential endogeneity of cooperative membership decisions. Using transaction cost economics as a theoretical framework, we employ three endogenous switching probit models to estimate the determinants of each marketing channel based on field survey data collected among 625 farming households in Shaanxi and Shandong provinces in China. The empirical results show that cooperative membership has a significantly positive effect on the choice of wholesalers as marketing channels, along with a negative effect on choosing small dealers and an insignificant effect on choosing cooperatives.

We can explain the varying effects of cooperative membership on farmers' choice of marketing channels in particular from the services provided by cooperatives. Cooperatives of apple farmers mainly provide marketing information services and marketing coordination activities to their members. As a result, current market shares of apple cooperatives are small (see also Table 3.2). Even if cooperatives do not buy their members' apples, most of them collect marketing information, introduce wholesalers to members and help coordinate transactions for members. Membership thus exerts a positive effect on the choice of wholesalers, a negative effect on the choice of small dealers, but no significant effect on the choice of cooperatives as the marketing channel.

We thus can conclude that the majority of the surveyed cooperatives are supply cooperatives, rather than marketing ones. Most of these cooperatives were established after 2007 and they are still young compared to other entities in the market. According to Cook and Burress's 
(2009) cooperative life cycle framework, they are still in the phase of economic justification or organizational design. Hence, it is not surprising that only a small share of the members sell their apples to the cooperatives. Cooperatives still need time to develop, and to realize their potential in facilitating smallholder access to markets and strengthening their economic position.

One important field in which cooperatives can play a crucial role is in improving food traceability. Due to the increasing purchasing power of consumers, technical developments of examining food safety, and especially the recent food scandals, there is growing attention for food traceability, food safety and food quality in China. Cooperatives are regarded as a form of collective action that can help realize food traceability and thus promote food safety (Narrod, et al., 2009). For China, Jia, et al. (2012a) find that those agricultural products that are sold to supermarkets and export firms via cooperatives meet stringent food safety standards and quality requirements. Products sold directly to small traders or wholesalers are generally not tested for their safety (Huang, et al., 2008). Our survey data also show that among the 30 households in our sample who had their apples tested for pesticide residues, 24 households (80\%) sold apples to cooperatives. However, we find that membership of apples cooperatives does not promote marketing apples through cooperatives. Promoting food quality and food safety therefore requires more than just promoting cooperative membership. In particular, a preferential treatment of marketing-oriented cooperatives may be justified from the public health aspects of the food quality improvements that such cooperatives are expected to generate.

The number of Chinese agricultural cooperatives has increased rapidly since 2006 . Over $40 \%$ of farm households had joined at least one cooperative by the end of 2015 . However, the market share held by cooperatives is still low. What role cooperatives play in the changing agricultural markets and how they can benefit both smallholder farmers and consumers in China are questions that still need to be further explored. Answers to these two questions not only concern the food safety of consumers, but also concern Chinese smallholder farmers' options in adapting to new high-value added markets and increasing their incomes. Our research only provides some first insights into the limited role played by apples cooperatives in the selling of products. More research is needed, particularly on the aforementioned two issues, to augment the science-based evidence needed for designing appropriate food policies that stimulate the role of farmers' cooperatives in promoting food quality and safety as well as smallholder welfare. 
One potential limitation of our research is that due to data constraints, we have only explored the determinants of farmers' choice of marketing channels from the perspective of farmers. If we would have data about buyers and other parties in the value chain, especially information about the flexibility of each marketing channel, the services provided and the prices offered by different buyers, we could use this to gain additional insights into farmers' choices of marketing channels. A fruitful future research direction would be to focus on collecting and analysing such detailed information on channel characteristics. 


\section{References}

Abebaw, D., Haile, M. G., 2013. The impact of cooperatives on agricultural technology adoption: Empirical evidence from Ethiopia, Food Policy. 38, 82-91.

Abebe, G. K., Bijman, J., Pascucci, S., Omta, O., 2013. Adoption of improved potato varieties in Ethiopia: The role of agricultural knowledge and innovation system and smallholder farmers' quality assessment, Agricultural Systems. 122, 22-32.

Angrist, J. D., 2001. Estimation of limited dependent variable models with dummy endogenous regressors: Simple strategies for empirical practice, Journal of Business and Economic Statistics. 19, 2-28.

Barrett, C. B., 2008. Smallholder market participation: Concepts and evidence from eastern and southern Africa, Food policy. 33, 299-317.

Bijman, J., 2016. The changing nature of farmer collective action: Introduction to the book, in J. Bijman, R. Muradian and J. Schuurman eds., Cooperatives, Economic Democratization and Rural Development. Edward Elgar Publishing Ltd., Cheltenham, UK.

Bijman, J., Iliopoulos, C., 2014. Farmers' cooperatives in the EU: Policies, strategies, and organization, Annals of Public and Cooperative Economics. 85, 497-508.

Cechin, A., Bijman, J., Pascucci, S., Omta, O., 2013. Decomposing the Member Relationship in Agricultural Cooperatives: Implications for Commitment, Agribusiness. 29, 39-61.

Chagwiza, C., Muradian, R., Ruben, R., 2016. Cooperative membership and dairy performance among smallholders in Ethiopia, Food Policy. 59, 165-173.

Cong, P., 2008. Report about the nationwide survey of apple cultivars, available.

Cook, M. L., Burress, M. J., 2009. A cooperative life cycle framework, International Conference 'Rural Cooperation in the 21st Century: Lessons from the Past, Pathways to the Future', Rehovot, Israel.

Deb, P., Trivedi, P. K., 2006. Maximum simulated likelihood estimation of a negative binomial regression model with multinomial endogenous treatment, The Stata Journal. 6, 246-255.

Deng, H., Huang, J., Xu, Z., Rozelle, S., 2010. Policy support and emerging farmer professional cooperatives in rural China, China Economic Review. 21, 495-507.

Fischer, E., Qaim, M., 2012. Linking smallholders to markets: Determinants and impacts of farmer collective action in Kenya, World Development. 40, 1255-1268.

Frederick, C., Liu, M., Wu, B., 2015. 2015 Fresh Deciduous Fruit Annual for China available.

Greene, W. H., 2008. Econometric Analysis. Pearson Education, Upper Saddle River, New Jersey.

Hansen, M. H., Morrow, J., Batista, J. C., 2002. The impact of trust on cooperative membership retention, performance, and satisfaction: An exploratory study, International Food and Agribusiness Management Review. 5, 41-59.

Heckman, J. J., 1978. Dummy endogenous variables in a simultaneously equation system, Econometrica. 46, 931-960.

Hellin, J., Lundy, M., Meijer, M., 2009. Farmer organization, collective action and market access in MesoAmerica, Food Policy. 34, 16-22.

Hendrikse, G., Bijman, J., 2002. Ownership structure in agrifood chains: the marketing cooperative, American Journal of Agricultural Economics. 84, 104-119.

Hoffman, S., Royer, J. S., 1997. Evaluating the competitive yardstick effect of cooperatives on imperfect markets: A simulation analysis, Western Agricultural Economics Association Annual Meeting, RenoSparks, Nevada.

Huang, S., Lin, J., Xu, X., 2008. Farmer cooperatives governance mechanisms and empirical analyzes of performance, Chinese Rural Economy, 65-73.

Jia, X., Huang, J., Luan, H., Rozelle, S., Swinnen, J., 2012a. China's Milk Scandal, government policy and production decisions of dairy farmers: The case of Greater Beijing, Food Policy. 37, 390-400.

Jia, X., Huang, J., Xu, Z., 2012b. Marketing of farmer professional cooperatives in the wave of transformed agrofood market in China, China Economic Review. 23, 665-674.

John, G., Weitz, B. A., 1988. Forward integration into distribution: An empirical test of transaction cost analysis, The Journal of Law, Economics, \& Organization 4, 337-355.

Kalogeras, N., Pennings, J. M., van der Lans, I., Garcia, P., van Dijk, G., 2009. Understanding heterogeneous preferences of cooperative members, Agribusiness. 25, 90-111.

Key, N., Sadoulet, E., De Janvry, A., 2000. Transactions costs and agricultural household supply response, American Journal of Agricultural Economics. 82, 245-259.

Kung, J., Cai, Y., Sun, X., 2009. Rural cadres and governance in China: Incentive, institution and accountability, The China Journal, 61-77.

La Ferrara, E., 2002. Inequality and group participation: Theory and evidence from rural Tanzania, Journal of Public Economics. 85, 235-273. 
Ménard, C., 2007. Cooperatives: Hierarchies or hybrids?, in K. Karantininis and J. Nilsson eds., Vertical Markets and Cooperative Hierarchies. Springer, Netherlands.

Masten, S. E., Meehan, J. W., Snyder, E. A., 1991. The costs of organization, Journal of Law, Economics, \& Organization. 7, 1-25.

Menard, S., 2002. Applied logistic regression analysis. Sage, Thousand Oaks, CA.

Milford, A. B., 2014. Co-operative or coyote? Producers' choice between intermediary purchasers and Fairtrade and organic co-operatives in Chiapas, Agriculture and human values. 31, 577-591.

Miranda, A., Rabe-Hesketh, S., 2006. Maximum likelihood estimation of endogenous switching and sample selection models for binary, ordinal, and count variables, Stata Journal. 6, 285-308.

Moustier, P., Tam, P. T. G., Anh, D. T., Binh, V. T., Loc, N. T. T., 2010. The role of farmer organizations in supplying supermarkets with quality food in Vietnam, Food Policy. 35, 69-78.

Mujawamariya, G., D’Haese, M., Speelman, S., 2013. Exploring double side-selling in cooperatives, case study of four coffee cooperatives in Rwanda, Food Policy. 39, 72-83.

Narrod, C., Roy, D., Okello, J., Avendaño, B., Rich, K., Thorat, A., 2009. Public-private partnerships and collective action in high value fruit and vegetable supply chains, Food Policy. 34, 8-15.

Palmatier, R., Stern, L., El-Ansary, A., Anderson, E., 2014. Marketing channel strategy. Pearson Prentice Hall, Upper Saddle River, NJ.

Pascucci, S., Gardebroek, C., Dries, L., 2012a. Some like to join, others to deliver: An econometric analysis of farmers' relationships with agricultural co-operatives, European Review of Agricultural Economics. 39, 51-74.

Pascucci, S., Royer, A., Bijman, J., 2012b. To Make or to Buy: Is this the Question? Testing making or buying decisions to explain innovation sourcing strategies in the food sector, International Food and Agribusiness Management Review. 15, 99-118.

Reardon, T., Crawford, E., Kelly, V., 1994. Links between nonfarm income and farm investment in African households: adding the capital market perspective, American Journal of Agricultural Economics. 76, 1172-1176.

Royer, A., 2011. Transaction costs in milk marketing: A comparison between Canada and Great Britain, Agricultural Economics. 42, 171-182.

Schultz, T. W., 1982. Investing in People: the Economics of Population Quality. University of California Press, Berkeley, CA.

Sexton, R. J., 1990. Imperfect competition in agricultural markets and the role of cooperatives: a spatial analysis, American Journal of Agricultural Economics. 72, 709-720.

Spanos, A., McGuirk, A., 2002. The problem of near-multicollinearity revisited: erratic vs systematic volatility, Journal of Econometrics. 108, 365-393.

Standifird, S. S., Marshall, R. S., 2000. The transaction cost advantage of guanxi-based business practices, Journal of World Business. 35, 21-42.

Swinnen, J. F. M., 2005. When the market comes to you-or not, available.

Sykuta, M. E., Cook, M. L., 2001. A new institutional economics approach to contracts and cooperatives, American Journal of Agricultural Economics. 83, 1273-1279.

Tan, S., Heerink, N., Kruseman, G., Qu, F., 2008. Do fragmented landholdings have higher production costs? Evidence from rice farmers in Northeastern Jiangxi province, PR China, China Economic Review. 19, 347-358.

Verhaegen, I., Van Huylenbroeck, G., 2001. Costs and benefits for farmers participating in innovative marketing channels for quality food products, Journal of Rural Studies. 17, 443-456.

Wang, L., Huo, X., 2014. Transaction costs comparison between cooperatives and conventional apple producers: A case study of northwestern China Ann. Public Coop. Econ. 85, 233-255.

Wiggins, S., Kirsten, J., Llambí, L., 2010. The future of small farms, World development. 38, 1341-1348.

Williamson, O. E., 1979. Transaction-cost economics: The governance of contractual relations, The Journal of Law and Economics. 22, 233-261.

Williamson, O. E., 1991. Comparative economic organization: The analysis of discrete structural alternatives, Administrative Science Quarterly. 36, 269-296.

Williamson, O. E., 1998. Transaction cost economics: How it works; Where it is headed, Economist. 146, 23-58.

Williamson, O. E., 2005. The economics of governance, American Economic Review. 95, 1-18.

Wollni, M., Zeller, M., 2007. Do farmers benefit from participating in specialty markets and cooperatives? The case of coffee marketing in Costa Rica, Agricultural Economics. 37, 243-248.

Wooldridge, J. M., 2010. Econometric analysis of cross section and panel data. MIT press, Cambridge, MA.

Wooldridge, J. M., 2014. Quasi-maximum likelihood estimation and testing for nonlinear models with endogenous explanatory variables, Journal of Econometrics. 182, 226-234. 


\section{Appendix: 3.1}

Table A.3.1 Switch model estimation results corresponding to other two marketing channels

\begin{tabular}{|c|c|c|c|c|}
\hline \multirow{2}{*}{ Variables } & \multicolumn{2}{|c|}{ small dealers } & \multicolumn{2}{|c|}{ cooperatives } \\
\hline & Coef. & S.E. & Coef. & S.E. \\
\hline gender & 0.396 & 0.397 & 0.412 & 0.377 \\
\hline area & $0.039^{* * * *}$ & 0.013 & $0.041^{*}$ & 0.022 \\
\hline$(\text { area })^{2}$ & 0.000 & 0.000 & 0.000 & 0.001 \\
\hline age & 0.001 & 0.007 & 0.001 & 0.007 \\
\hline education & $0.045^{* *}$ & 0.023 & $0.045^{*}$ & 0.023 \\
\hline household size & -0.001 & 0.044 & 0.000 & 0.044 \\
\hline training & $0.130^{* * * *}$ & 0.029 & $0.127^{* * *}$ & 0.030 \\
\hline skill level & $0.249^{* * * *}$ & 0.077 & $0.258^{* * *}$ & 0.078 \\
\hline region & 0.141 & 0.142 & 0.151 & 0.145 \\
\hline apple brokers & -0.121 & 0.128 & -0.139 & 0.129 \\
\hline plots & 0.047 & 0.030 & $0.052^{*}$ & 0.030 \\
\hline distance & 0.003 & 0.007 & 0.004 & 0.007 \\
\hline weather loss & 0.105 & 0.129 & 0.095 & 0.131 \\
\hline ex-ante risk1 & -0.030 & 0.040 & -0.027 & 0.040 \\
\hline ex-ante risk2 & 0.026 & 0.053 & 0.021 & 0.053 \\
\hline during-risk & 0.009 & 0.038 & 0.010 & 0.038 \\
\hline ex-post risk & 0.047 & 0.036 & 0.050 & 0.037 \\
\hline initiation & 0.000 & 0.102 & -0.010 & 0.109 \\
\hline village cadre & $0.235^{*}$ & 0.133 & 0.221 & 0.143 \\
\hline _cons & -2.234 & 0.740 & $-2.279^{* * * *}$ & 0.730 \\
\hline
\end{tabular}

Note: ${ }^{*}$ Denotes significance at $10 \% ;{ }^{* *}$ Denotes significance at $5 \% ;{ }^{* * *}$ Denotes significance at $1 \%$. 
Appendix: 3.2

Table A.3.2 2SLS-LPM regression results

\begin{tabular}{|c|c|c|c|c|c|c|}
\hline \multirow{2}{*}{ Variables } & \multicolumn{2}{|c|}{ wholesalers } & \multicolumn{2}{|c|}{ small dealers } & \multicolumn{2}{|c|}{ cooperatives } \\
\hline & Coef. & S.E. & Coef. & S.E. & Coef. & S.E. \\
\hline membership & $0.557^{* *}$ & 0.261 & $-0.567^{* *}$ & 0.248 & 0.008 & 0.146 \\
\hline gender & 0.047 & 0.166 & -0.057 & 0.158 & 0.017 & 0.093 \\
\hline quality & 0.002 & 0.001 & -0.001 & 0.001 & 0.000 & 0.001 \\
\hline area & -0.004 & 0.005 & 0.002 & 0.005 & 0.003 & 0.003 \\
\hline$(\text { area })^{2}$ & 0.000 & 0.000 & 0.000 & 0.000 & 0.000 & 0.000 \\
\hline non-farm work & 0.116 & 0.073 & $-0.136^{* *}$ & 0.069 & 0.019 & 0.041 \\
\hline specialisation & 0.173 & 0.108 & $-0.232^{* *}$ & 0.103 & $0.105^{*}$ & 0.060 \\
\hline age & -0.003 & 0.003 & 0.002 & 0.003 & -0.001 & 0.002 \\
\hline education & -0.005 & 0.011 & -0.006 & 0.011 & 0.007 & 0.006 \\
\hline household size & $-0.035^{*}$ & 0.018 & 0.017 & 0.017 & $0.020^{* *}$ & 0.010 \\
\hline skill level & -0.031 & 0.041 & 0.006 & 0.039 & 0.023 & 0.023 \\
\hline region & $0.118^{*}$ & 0.064 & -0.061 & 0.061 & -0.046 & 0.036 \\
\hline apple brokers & $0.204^{* * *}$ & 0.055 & -0.084 & 0.052 & $-0.108^{* * *}$ & 0.031 \\
\hline plots & 0.013 & 0.013 & -0.018 & 0.012 & $0.015^{* *}$ & 0.007 \\
\hline distance & $0.005^{*}$ & 0.003 & -0.004 & 0.003 & 0.001 & 0.002 \\
\hline weather loss & -0.038 & 0.055 & 0.037 & 0.053 & $0.051^{*}$ & 0.031 \\
\hline ex-ante risk1 & 0.008 & 0.017 & 0.013 & 0.016 & -0.010 & 0.009 \\
\hline ex-ante risk2 & 0.009 & 0.022 & 0.003 & 0.021 & -0.018 & 0.012 \\
\hline during-risk & $-0.033^{* *}$ & 0.016 & $0.029^{* *}$ & 0.015 & -0.008 & 0.009 \\
\hline ex-post risk & -0.014 & 0.016 & 0.020 & 0.015 & 0.005 & 0.009 \\
\hline constant & 0.061 & 0.363 & $0.820^{* *}$ & 0.346 & -0.111 & 0.204 \\
\hline no. of observ. & 625 & & 625 & & 625 & \\
\hline$\chi^{2}$ (Durbin score) & & $7.128^{* * * *}$ & & $5.008^{* * *}$ & & \\
\hline F (Wu-Hausman) & & $6.956^{* * * *}$ & & $4.870^{* *}$ & & \\
\hline
\end{tabular}

Note: S.E. denotes standard errors. 


\section{Appendix: 3.3}

Table A.3.3 Bivariate Probit model (BPM) regression results

\begin{tabular}{|c|c|c|c|c|c|c|}
\hline \multirow{2}{*}{ Variables } & \multicolumn{2}{|c|}{ wholesalers } & \multicolumn{2}{|c|}{ small dealers } & \multicolumn{2}{|c|}{ cooperatives } \\
\hline & Coef. & S.E. & Coef. & S.E. & Coef. & S.E. \\
\hline membership & $0.994^{* * *}$ & 0.272 & $-1.116^{* * * *}$ & 0.352 & 0.201 & 0.769 \\
\hline gender & 0.153 & 0.382 & -0.190 & 0.383 & -0.052 & 0.539 \\
\hline quality & $0.006^{* *}$ & 0.003 & -0.003 & 0.003 & 0.003 & 0.005 \\
\hline area & $-0.038^{*}$ & 0.020 & 0.029 & 0.022 & 0.030 & 0.029 \\
\hline$(\text { area })^{2}$ & $0.001^{*}$ & 0.000 & -0.001 & 0.001 & 0.000 & 0.001 \\
\hline non-farm work & 0.231 & 0.145 & $-0.311^{* * *}$ & 0.160 & 0.092 & 0.235 \\
\hline specialisation & $0.450^{* *}$ & 0.229 & $-0.622^{* * *}$ & 0.246 & 0.589 & 0.378 \\
\hline age & -0.007 & 0.007 & 0.006 & 0.007 & -0.002 & 0.010 \\
\hline education & -0.003 & 0.023 & -0.023 & 0.026 & 0.040 & 0.035 \\
\hline household size & $-0.078^{*}$ & 0.043 & 0.043 & 0.043 & $0.119^{*}$ & 0.063 \\
\hline skill level & -0.049 & 0.081 & -0.018 & 0.088 & 0.126 & 0.118 \\
\hline region & $0.349^{* *}$ & 0.147 & -0.235 & 0.148 & -0.298 & 0.204 \\
\hline apple brokers & $0.453^{* * *}$ & 0.120 & -0.195 & 0.122 & $-0.707^{* * *}$ & 0.186 \\
\hline plots & 0.043 & 0.029 & $-0.065^{* *}$ & 0.033 & 0.053 & 0.034 \\
\hline distance & $0.012^{*}$ & 0.007 & $-0.012^{*}$ & 0.007 & 0.006 & 0.009 \\
\hline weather loss & -0.075 & 0.123 & 0.087 & 0.127 & 0.365 & 0.198 \\
\hline ex ante TU1 & 0.018 & 0.037 & 0.033 & 0.039 & -0.076 & 0.054 \\
\hline ex ante TU2 & 0.012 & 0.049 & 0.015 & 0.050 & -0.104 & 0.068 \\
\hline during TU & $-0.075^{* *}$ & 0.036 & $0.071^{* * *}$ & 0.037 & -0.037 & 0.051 \\
\hline ex post TU & -0.030 & 0.034 & 0.045 & 0.035 & 0.028 & 0.049 \\
\hline constant & -1.057 & 0.818 & 0.969 & 0.828 & $-2.775^{*}$ & 1.170 \\
\hline$\rho$ & $-0.686^{* * *}$ & 0.170 & $0.590^{* * *}$ & 0.231 & 0.201 & 0.769 \\
\hline $\begin{array}{l}\text { No. of } \\
\text { observations }\end{array}$ & 625 & & 625 & & 625 & \\
\hline
\end{tabular}

Note: S.E. denotes standard errors. 



\title{
4. Cooperative Membership and Smallholder s' Yields and Profits- Evidence from apple farmers in China1
}

\begin{abstract}
Cooperatives are regarded as an institutional vehicle to help farmers mitigate market imperfections and improve smallholder welfare. Though much research has been done on what effect cooperatives have on farmers' welfare, the pathway through which cooperatives affect farmers' welfare remains largely undiscovered. We examine the effect of cooperative membership on yields and profits by using the field survey data collected among 551 apple farm households in Shaanxi and Shandong Provinces, China. Endogenous treatment regression models are employed to assess the average treatment effects of cooperative membership on the yield and profits per unit area. We find that cooperative membership has a significantly positive effect on yield, but no significant effect on profits per unit area. Two pathways explain the different effects. First, cooperative services change members' production practices, especially the use of inputs that lead to higher land productivity. Second, members on average spend more on fertilizers and use more hired labor than nonmembers, which results in higher production costs. The extra revenues generated by the increased yields roughly compensates the extra production costs of the members.
\end{abstract}

Key words

Cooperatives, apple farmers, yields, profits, China

\footnotetext{
${ }^{1}$ Unpublished paper by Jinghui Hao, Nico Heerink, Jos Bijman and Wim Heijman.
} 


\subsection{Introduction}

Smallholder farmers play a vital role in the global agricultural community. Collectively, they manage four-fifths of the world's small farms and provide over $80 \%$ of the food consumed in the developing countries. One billion out of the 1.4 billion poor people living on less than US\$1.25 per day earn their living from agriculture (IFAD, 2013). To combat rural poverty, developing countries have been trying to improve small-scale farms' productivity and profitability (Verhofstadt and Maertens, 2014b). Small-scale farms often face sincere market failures, which impede their access to markets and the possibility to improve productivity growth.

Cooperatives can help farmers overcome market failures. They can facilitate farmers' participation and improve their bargaining power through joining forces in both input and output markets, thereby increasing agricultural income and reduce rural poverty (Fischer and Qaim, 2012; Markelova et al., 2009). Compared with contract farming or other types of institutions, a cooperative is generally more inclusive of smallholders, because of advantages in collective actions and social capital (Verhofstadt and Maertens, 2014a).

One constraint on the development of modern agriculture in China is land fragmentation and small-scale farms, which can be ascribed to the household responsibility system since 1979 (Tan, et al., 2008). Under circumstances of vertical coordination of a supply chain, small farmers become increasingly vulnerable in the negotiation with other traders in the market. To facilitate the smallholders' market access, Chinese government has been enhancing the development of cooperatives since the beginning of the 21st century. By October 2015, over $40 \%$ of farm households had become members of at least one cooperative ${ }^{1}$.

A considerable body of research has examined cooperatives' effectiveness. On the one hand, for example, Wollni and Zeller (2007) and Sauer, et al. (2012) indicate that cooperatives can improve the coffee and milk prices that farmers in Costa Rica and CIS countries received, respectively. Abebaw and Haile (2013) and Verhofstadt and Maertens (2014b) find that cooperatives promote the use of chemical fertilizers and agricultural innovations, which contributes to improved agricultural productivity and increase farm incomes. On the other,

\footnotetext{
1 Translated by authors from the news report entitled " 1.47 million cooperatives including $40 \%$ of farmer households nationwide". The original text is written in Chinese and was released on January 1, 2016; it can be found at http://politics.people.com.cn/n1/2016/0111/c1001-28035566.html.
} 
Addai, et al. (2014) find that farmer organization membership exerts no significant impact on the yields or technical efficiency of maize farmers in Ghana.

In the case of watermelon farmers in China, Ito, et al. (2012) claim that a cooperative enables smallholders to increase farm incomes and is an important avenue to improve their economic status. Similarly, Ma and Abdulai (2016) show that apple cooperative membership can improve yields and household incomes. Both studies have examined the effects of cooperative membership on farmers' welfare in China. However, these studies do not examine the question how cooperatives affect farmers' welfare. Insights into this question can be useful to evaluate the Chinese policy of developing modern agriculture by promoting farmers to participate in farmer cooperatives and to foster other new types of agricultural business entities $(\mathrm{Hu}, 2012)$. The objective of this paper is to fill this research gap by examining the mechanism through which cooperative membership affects yields and the profits.

We focus our analysis on apple farmers. As the world's leading producer of apples, China produced more than half of the total apple output in 2015 (Frederick et al., 2015). Apples are the fruit crop with the largest acreage and the highest production value in China.

Furthermore, they have been the dominant income source of farmers in the two main apple production regions: the Bohai Gulf area and the Loess Plateau area (Wang and Huo, 2014). The empirical analysis is based on field survey data collected among 551 apple farm households in Shaanxi Province located in the Loess Plateau and Shandong Province in Bohai Gulf. We employ the endogenous treatment regression model (ETRM) to control for potential endogeneity of cooperative membership in estimating its effect on yields and profits. Given that the ETRM allows interactions between treatment and outcome covariates, we examine the pathway through which cooperative membership affects yields and the profits.

\subsection{Conceptual framework}

Figure 1 shows the mechanism through which cooperative membership is expected to affect farmers' yields and their profits per unit area.

Generally, cooperatives can help dismantle obstacles caused by market failures due to, for instance, distorted input and output markets and missing credit markets, and facilitate farmers' market access (Markelova, et al., 2009). Firstly, cooperatives can improve farmers' 
barging power and market access through joint collaboration, which allows members to obtain inputs at a lower price and to sell products at a higher price. Secondly, cooperatives can offer specific trainings, technical assistance and other extension services of production. Research shows that cooperatives generally increase the probability of adopting artificial fertilizers and other improved technologies (Abebaw and Haile, 2013, Verhofstadt and Maertens, 2014a). Therefore, we assume that these services not only improve members' total factor productivity, but also members' production practices. Particularly, the application of inputs (both in quality and quantity) affect both the quality and quantity of output (yield), which impact the production costs and thus profits from production. Thirdly, cooperatives can smooth the information flow between farmers and the market. Hence, farmers can produce to better meet market requirements (Thorp, et al., 2005, Wollni and Zeller, 2007). In addition, cooperatives also assist members with product marketing by either buying products from their members or sharing marketing information. The marketing service will affect the output price received by members.

Given the reasons above, we assume that member farmers can have more production advantages than non-members. We only focus on the analysis of the mechanism of the effect of cooperatives on farmers' yields and profits from the input aspect, without considering external environmental factors (e.g. the output prices and available marketing channels) in this paper. In Figure 1, the unexamined part has been shown in Italic font and the unstudied relationship in dashed arrows. 


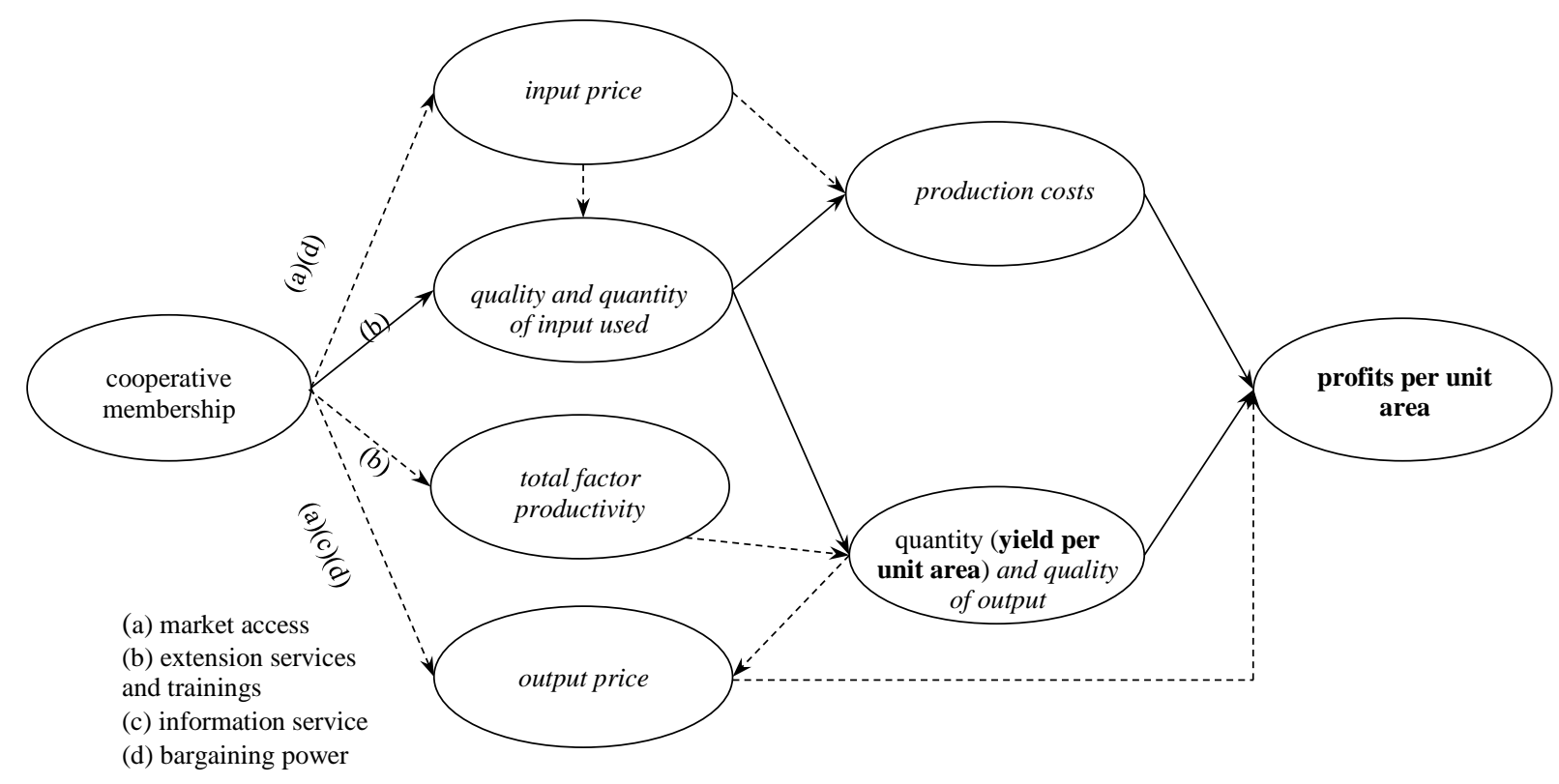

(External factors are not shown here.)

Note: Words in Italic font stand for the unexamined.

Figure 3.1 Conceptual

\subsection{Farm Survey}

We conducted a survey among farm households between January and March $2015^{1}$ in Shaanxi Province in the Loess Plateau area and Shandong Province in the Bohai Gulf area. A multistage sampling procedure was used for the selection of observation units. In the first stage, we used the probability proportional to size (PPS) method to select 7 counties (out of the 10 most important apple production counties) in Shaanxi and 8 counties (out of the 10 most important apple production counties) in Shandong according to the size of apple production in 2014. In the second stage, we asked the Agricultural Bureau in each county for the list of apple cooperatives in the county. 5 cooperatives were randomly selected from those lists. Therefore, in total we first selected 75 cooperatives. However, the chairmen of 12 out of the 75 selected cooperatives could not be reached. We dropped these 12 cooperatives from our sample, resulting in a final sample of 63 cooperatives that were interviewed (30 in Shaanxi and 33 in Shandong). We did face-to-face interviews with the chairperson or other officials involved in cooperative management.

\footnotetext{
${ }^{1}$ Our survey was conducted in two periods, before and after the Spring Festival.
} 
Next, 10 to 12 farm households were interviewed in the village where a cooperative is located. At least 6 cooperative members in each village were interviewed. This gave a total number of 700 farm households that were interviewed, composed of 429 member farm households and 271 non-member households. Information was collected on apple production in 2009 and 2014 (including input use, costs and yields), and household and farm characteristics (e.g., age, education and farm size). The collected information was based as much as possible on written records; for farmers that did not keep records it was based on recall data. Some of the interviewed farmers had not yet sold the apples harvested in 2014 . We excluded these farmers from our analysis. Therefore, data from 551 farmer households can be used for analyzing the determinants of yield. Specifically, 336 member farmers (185 in Shaanxi and 151 in Shandong) and 215 non-member farmers (109 in Shaanxi and 106 in Shandong) were used in the analysis.

Given the data availability, we analyze the effect of cooperatives on farmers' yields and profits through the quality and quantity of input used. Therefore, we do not examine other factors of farmers' profits such as marketing channels, output prices, and other external environmental factors.

\subsection{Estimation methodology}

\subsubsection{Econometric framework}

Based on our conceptual framework, we build the Cobb-Douglas production function (Debertin, 1986). The logarithm form of the production function can be written as:

$\ln Y=\alpha_{0}+\alpha_{1} \ln K+\alpha_{2} \ln L+\alpha_{3} \ln T+\alpha_{4} \ln I+\gamma C+\delta Z$

Where $Y$ is the yield; $\alpha_{0}$ is the constant; $K, L$ and $T$ represent the capital, labor and land inputs, respectively; $I$ is a vector of variable inputs for agricultural production, $C$ is a vector of product- and farmer-specific characteristics variables and $Z$ is a vector of membership dummy variables. $\alpha_{0^{-}} \alpha_{4}, \gamma$ and $\delta$ are the coefficients to be estimated.

It is well-known that a profit function can be expressed with the same explanatory variables as a production function when input and output prices do not vary among the units of observations. We assume that the cooperative services lead to different production practices among farmers, especially the application of inputs. We thus assume that the fixed production factors $(\mathrm{K}, \mathrm{L}$ and $\mathrm{T})$ as well as the product- and farmer-specific characteristics $(\mathrm{C})$ have a 
similar impact on yields for members and non-members, but that the impact of variable inputs differs between the two groups. The mechanism through which cooperative membership affects the yield can be written as:

$$
\begin{aligned}
& \ln Y_{0}=\alpha_{0}+\alpha_{1} \ln K+\alpha_{2} \ln L+\alpha_{3} \ln T+\sum_{j=1}^{j} \beta_{0 j} \ln I_{j}+\gamma C \\
& \ln Y_{1}=\alpha_{0}+\alpha_{1} \ln K+\alpha_{2} \ln L+\alpha_{3} \ln T+\sum_{j=1}^{j} \beta_{1 j} \ln I_{j}+\gamma C
\end{aligned}
$$

where $Y_{0}$ and $Y_{1}$ denote the yield obtained by non-members and members, respectively; $j$ is the number of variable inputs; $\beta_{0 \mathrm{j}}$ and $\beta_{1 \mathrm{j}}$ are the parameters of different effects of variable inputs on the yield for non-members and members, respectively, keeping all other variables constant. The profit functions can be expressed in a similar way:

$$
\begin{aligned}
& \ln P_{0}=\theta_{0}+\theta_{1} \ln K+\theta_{2} \ln L+\theta_{3} \ln T+\sum_{j=1}^{j} \omega_{0 j} \ln I_{j}+\sigma C+\tau S \\
& \ln P_{1}=\theta_{0}+\theta_{1} \ln K+\theta_{2} \ln L+\theta_{3} \ln T+\sum_{j=1}^{j} \omega_{1 j} \ln I_{j}+\sigma C+\tau S
\end{aligned}
$$

where $P_{0}$ and $P_{1}$ denote the profits per unit area obtained by non-members and members, respectively; $\theta_{0}$ is a constant; $\theta_{1}, \theta_{2}$ and $\theta_{3}$ are the parameters of capital, labor and land inputs to be estimated, respectively; $\omega_{0 j}$ and $\omega_{1 j}$ are the parameters of different effects of variable inputs on the profit to be estimated for non-members and members respectively, keeping all other variables constant. $S$ denotes the variables that are excluded in the yield function but included in the profit function, e.g. apple quality.

\subsubsection{Endogeneity of cooperative membership}

Equations (1) -(5) assume that farmer $i$ 's choice of membership is exogenous to yields and the profits from apple production. However, farmers may self-select to join cooperatives because of unobserved factors such as incentives and farming ability. These unobservable factors may also impact product yields and profits, which makes the error terms of the membership equation correlate with that of the output equations. In such a case, membership is endogenous in both yield and profit equations. Neglecting or failing to account for endogeneity will bring about inconsistent estimates and lead to spurious or even biased conclusions (Heckman, 1979, Gerber, 1998).

\subsubsection{Treatment effects assessment}

A treatment effect is the average causal effect of a binary variable on an outcome variable of scientific or policy interest. In practice, simple comparisons of the outcome between the two groups or even regression-adjusted comparisons may provide misleading estimates of 
treatment effects because of endogeneity due to unobserved and uncontrolled differences between the control and the treatment groups. Matching and instrumental variables (IV) are the two most commonly used statistical techniques to solve the problem of endogeneity when estimating treatment effects (Angrist, 2010). Both matching and IV regression are motivated by the assumption that the only source of omitted variables or selection bias is from observed covariates based on the conditional independence assumption (Angrist, 2010). Propensity Score Matching (PSM) has been one of the popular methods to evaluate treatment effects. But the obvious disadvantage of PSM is that it only controls for observed heterogeneity. The IV method can avoid this disadvantage and control for unobserved heterogeneity in principle (Kabunga, et al., 2012). A typical IV treatment effects model is composed of one selection equation and one outcome equation, which assumes that the impact of the selection can be captured by a simple parallel shift with respect to the outcome variable (Kabunga, et al., 2012). This assumption does not fit the fact that cooperative membership is expected to influence not only the output (e.g. yield and net returns from products), but also the input use during the production. These interactions can be depicted through the estimation of the endogenous treatment-regression model (ETRM), which allows interactions between treatment and outcome covariates.

We measure the treatment effect through the average treatment effect (ATE), the average treatment effect on the treated (ATET) and the average treatment effect on the untreated (ATEU). The specific details of ETRM and treatment models can be found in STATA Glossary and Index (Release 14, pp. 36-67).

\subsubsection{Model specification}

\subsubsection{Outcome equations}

Based on the forms of capital categorized by Uphoff and Wijayaratna (2000), we group the explanatory variables into six different categories, viz. social capital, physical assets, human capital, variable inputs, local physical environment and social environment. We measure the profit as farmers' average profits ${ }^{1}$ from apple production per unit of land in 2014. Table 4.1 shows the definitions of the variables and expected effects of the independent variables used in the estimation of both the treatment equation and outcome equations.

\footnotetext{
1 The cost of family-member-labour (or free labour) input and indirect fixed costs are not subtracted from the average net income.
} 
Table 4.1 Descriptions of variables and expected effects

\begin{tabular}{|c|c|c|c|c|c|}
\hline & $\begin{array}{l}\text { Variable } \\
\text { Name }\end{array}$ & $\begin{array}{l}\text { Expected } \\
\text { effects on } \\
\text { yield } / m u\end{array}$ & $\begin{array}{l}\text { Expected } \\
\text { effects on } \\
\text { profits } / m u\end{array}$ & $\begin{array}{l}\text { Expected } \\
\text { effects on } \\
\text { membership }\end{array}$ & Description \\
\hline \multirow{3}{*}{ Output } & log_yield & n.a. & n.a. & n.a. & logarithm of yield per $m u^{1}\left(\right.$ unit: $\left.j i n^{2}\right)$ \\
\hline & log_profit & n.a. & n.a. & n.a. & $\begin{array}{l}\text { logarithm of profit from apple production per } m u \text { in } \\
2014 \text { (unit: yuan) }\end{array}$ \\
\hline & membership & $+/-$ & $+/-$ & n.a. & cooperative membership \\
\hline \multirow[t]{6}{*}{ Social capital } & village cadre & $+/-$ & $+/-$ & + & $\begin{array}{l}\text { whether the household head or any other family } \\
\text { member has the work experience of being village cadre } \\
(1=\text { yes; } 0=\text { no) }\end{array}$ \\
\hline & fruit_year & $+/-$ & $+/-$ & n.a. & age of apple trees \\
\hline & $\begin{array}{l}\text { dwarf } \\
\text { rootstock }\end{array}$ & $+/-$ & $+/-$ & n.a. & $\begin{array}{l}\text { whether the apple trees are grafted on dwarf rootstocks } \\
(1=\text { yes; } 0=\text { no })\end{array}$ \\
\hline & land size & $+/-$ & $+/-$ & $+/-$ & area of land bearing apples (unit: $m u$ ) \\
\hline & plots & $+/-$ & $+/-$ & n.a. & number of land plots cultivated by the household \\
\hline & specialization & n.a. & + & $+/-$ & share of the land area allocated to apple production( $\%)$ \\
\hline \multirow[t]{5}{*}{ Physical asset } & quality & n.a. & + & $+/-$ & $\begin{array}{l}\text { the ratio of apples without blemishes in the total apple } \\
\text { output in } 2009\end{array}$ \\
\hline & income_2009 & + & + & $+/-$ & $\begin{array}{l}\text { total incomes from apple production in } 2009 \text { (unit: } \\
\text { yuan) }\end{array}$ \\
\hline & non-farm & n.a. & n.a. & $+/-$ & $\begin{array}{l}\text { if the household head participates in non-farm work }=1 \text {, } \\
\text { otherwise }=0 \text { ) }\end{array}$ \\
\hline & gender & $+/-$ & $+/-$ & $+/-$ & gender of the household head ( $1=$ male; $0=$ female $)$ \\
\hline & age & $+/-$ & $+/-$ & $+/-$ & age of the household head \\
\hline \multirow[t]{5}{*}{ Human capital } & education & + & + & + & years of education of the household head \\
\hline & training & n.a. & n.a. & + & frequency of participation in technical training in 2009 \\
\hline & skill level & + & + & + & $\begin{array}{l}\text { self-evaluated level of producing skills } \\
\text { (1=bad;2=mediocre;3=good;4=excellent) }\end{array}$ \\
\hline & fertilizer & + & $+/-$ & n.a. & $\begin{array}{l}\text { total fertilizer cost per } m u \text { for apple production (unit: } \\
\text { yuan) }\end{array}$ \\
\hline & pesticide & + & $+/-$ & n.a. & $\begin{array}{l}\text { total pesticides cost per } m u \text { for apple production (unit: } \\
\text { yuan) }\end{array}$ \\
\hline \multirow{5}{*}{$\begin{array}{l}\text { Variable } \\
\text { inputs }\end{array}$} & family labour & + & $+/-$ & n.a. & $\begin{array}{l}\text { own family-labour input per } m u \text { for apple production } \\
\text { (unit: labour days) }\end{array}$ \\
\hline & hired labour & + & $+/-$ & n.a. & $\begin{array}{l}\text { hired-labour input per } m u \text { for apple production (unit: } \\
\text { labour days) }\end{array}$ \\
\hline & irrigation & + & $+/-$ & n.a. & frequency of irrigation for apple trees in 2014 \\
\hline & bagging & + & $+/-$ & n.a. & $\begin{array}{l}\text { whether double-layer bags have been used for bagging } \\
\text { apples in } 2014 \text { ( } 1=\text { yes; } 0=\text { no })\end{array}$ \\
\hline & weather & - & - & n.a. & $\begin{array}{l}\text { whether there is production loss caused by extreme } \\
\text { weather in } 2014(1=\text { yes; } 0=\text { no })\end{array}$ \\
\hline \multirow{3}{*}{$\begin{array}{l}\text { Local physical } \\
\text { environment }\end{array}$} & loss & n.a. & n.a. & + & $\begin{array}{l}\text { whether there was production loss caused by extreme } \\
\text { weather from } 2009 \text { to } 2013(1=\text { yes; } 0=\text { no })\end{array}$ \\
\hline & distance & n.a. & n.a. & + & $\begin{array}{l}\text { distance to the nearest agricultural spot market (unit: } \\
\mathrm{km} \text { ) }\end{array}$ \\
\hline & region & $+/-$ & $+/-$ & $+/-$ & regional dummy variable $(1=$ Shaanxi; $0=$ Shandong) \\
\hline \multirow{2}{*}{$\begin{array}{l}\text { Social } \\
\text { environment }\end{array}$} & test & n.a. & n.a. & + & $\begin{array}{l}\text { whether local cooperative development is one criteria } \\
\text { for evaluating the performance of village cadres }(1= \\
\text { yes; } 0=\text { no })\end{array}$ \\
\hline & organization & n.a. & n.a. & + & $\begin{array}{l}\text { the number of entertainment organizations for villagers } \\
\text { in the village }\end{array}$ \\
\hline
\end{tabular}

Note: “+”, “-” and "0" stand for positive effect, negative effect and no effect, respectively. "+/_" denotes ambivalent effect.

\footnotetext{
${ }^{1} \mathrm{mu}$ is the traditional Chinese unit of area $(1$ hectare $=15 \mathrm{mu})$.

2 jin is the traditional Chinese unit of weight $(1 \mathrm{~kg}=2$ jin $)$
} 
The focus of our research is the effect of cooperative membership on farmers' yields and profits. Therefore, the membership variable is the most important explanatory variable in this paper. Based on the majority of the existing literature, we assume that cooperative membership has positive effect on both yields and profits (Wollni and Zeller, 2007; Sauer et al. 2012). To some extent, cooperative membership can be a measurement of an aspect of social capital. Whether the family members have work experience as a village cadre is used as a second proxy of social capital. Given that literature can be found about both the positive (Grootaert, 1999) and negative effect (Adhikari and Goldey, 2010, Crespo, et al., 2014) of social capital on household welfare and collective action, we cannot specify the signs of the effects of village cadre on production yield or profits per unit area.

Physical assets include age of apple trees and the rootstock of apples grafted on), land size (indicated by the area of land bearing apples), degree of land fragmentation (measured by number of plots each household owns), level of specialization in apple production (indicated by the share of land allocated to apple production) and the fruit quality. It has been proven that tree age and rootstocks of apple cultivar grafted on partly determine the size of apples (Marini, et al., 2002, Treder, et al., 2010) and hence both the yields and profits. Farm characteristics, such as land size and number of plots each household owns, have a direct effect on yields. For example, on the one hand, large farms can decrease production costs due to the economy of scale and their higher flexibility in crop use and risk bearing (Chambers and Foster, 1983). On the other hand, the negative relationship between farm size and output can be found in the research by Otsuka, et al. (2007) and Lipton (2009). Following the previous research, we assume that both the relationship between tree age and yields and the relationship between land size and yields and profits are quadratic. Additionally, farmers with more plots for a given farm size use more labor and fewer modern technologies, which tends to increase the production cost (Tan et al., 2008). Specifically, we need to note that the variables of quality and the degree of specialization in apple production are not included in the estimation of the determinants of yield, but is included in the profit equation.

Total income from apple production in 2009 and a dummy whether the household head participates in non-farm work are used as proxies of liquidity. We expect that easier access to cash and credit can decrease liquidity constraints for farmers to invest in production. The adequate liquidity imposes positive effect on apple yields, but ambivalent impact on the profit from apples. 
Human capital increases "the ability to perceive, interpret, and respond to new events in a context of risk" (Schultz and Schultz, 1982). Here human capital is indicated by household head's education, age, gender and self-evaluated level of apple producing skills. The expected effects of age and gender on yields and profits are not explicit, but education is expected to be positive.

Variable inputs for production mainly includes fertilizers, pesticides, labor input (including own family labor and hired labor), bagging and irrigation costs during the growth period. Input use is expected to have positive effects on yields, but an unclear effect on profits.

The local physical environment is represented by production loss caused by extreme weather during the growth period in 2014 and a regional dummy variable to distinguish the different agro-climatic characteristics between Shaanxi and Shandong. Extreme weather can harm both the yield and the profits from apple production.

\subsubsection{Cooperative membership}

The aim of the treatment equation is not to perfectly explain farmers' decisions about cooperative membership, but to account for unobserved heterogeneity that could bias the effect of membership on either apple yields or profits in the outcome equations. In principle, the parameters of the model (consisting of both treatment and outcome equations) can be identified, even though the treatment equation uses identical covariates as the outcome equation. However, Deb and Trivedi (2006) suggest that using exclusive restrictions or instruments can result in more robust identifications.

We thus include four extra variables in the treatment equation as instruments: (1) a dummy weather loss variable (whether the household suffered apple production loss caused by extreme weather from 2009 to 2013); (2) the frequency of accepting trainings of apple production in 2009; (3) whether the local cooperative development is one of the criteria for evaluating the village carder's performances or not; (4) the number of entertainment organisations for the villagers in the village. Reasons for choosing these four variables as instruments are as follows. (1) Extreme weathers can harm the apple quality. Farmers usually have difficulties in marketing the degraded apples. Cooperatives tend to buy members' apples of all grades including degraded ones because of marketing contracts before harvest. Experience of marketing difficulties before 2014 can affect farmers' membership decision, but not apple yields or profits. (2) Given the service provided by most cooperatives in China, some farmers, especially the ones needing trainings to improve their production skills, are 
more likely to participate in cooperatives than others. Trainings in 2009 can impact on the yields and profits in 2009, but little impact on those of 2014. In contrast, trainings in 2009 can influence farmers' membership in 2014. Variables (3) and (4) concern with social environment, which are not assumed to impact individuals' apple production, but positively impact on membership decisions.

Additionally, we include variables of farm characteristics and of human capital in the equation. Specifically, the degree of specialization may also influence the incentive to participate in group activities (Fischer and Qaim, 2014). We thus also include the variable of specialization in the membership equation.

\subsection{Descriptive analysis}

Table 4.2 shows the mean and standard deviation values of dependent and independent variables and the mean differences between member farmers and non-member farmers. Mean yield per $m u^{l}$ for members is $4,140 j i n^{2}$ or $2,070 \mathrm{~kg}$, about $290 \mathrm{jin}$ more than non-member farmers. The yield difference is not significantly different from zero. Mean profits from apple production per $m u$ for members are 7,838 yuan $\left(1043\right.$ euro $\left.^{3}\right)$ and 7,498 yuan (998 euro) for non-members. The difference between these two groups is 340 yuan, and is not statistically significant.

In general, apple farmer households are highly specialized in apple production. On average $84 \%$ of total land has been allocated to apple production. Their farms are dispersed ( 3.71 plots per household on average) and small ( $8.59 \mathrm{mu}$ or $0.57 \mathrm{Ha}$ on average). Though no significant difference exists between these two groups relating to land size, members have significantly more plots (with the mean of 3.84 plots) of land than non-member farmers. There is no significant differences between the two groups with respect to physical assets and variable inputs in production. However, differences in human capital and social capital are significant. Compared with non-members, member farmers have higher education levels and participate in more production trainings. Member farmers and their family members also have a higher probability of being village cadres.

\footnotetext{
${ }^{1} \mathrm{Mu}$ is a Chinese unit of area. 1 hector $=15 \mathrm{mu}$.

2 jin is the traditional Chinese unit of weight $(1 \mathrm{~kg}=2$ jin $)$.

${ }^{3}$ The calculation is based on the exchange rate of EURO to RMB on 31-12-2014: 1 EURO=7.512 RMB.
} 
In regard to variable inputs, there is no significant difference between the two groups except for the labour days and bagging. Labour is one of the most important components of costs for apple production ${ }^{1}$. Specifically, non-member farmers use more own family-labour per $m u$ than member farmers do. Member farmers tend to use more hired labour during production, though the total labour input on average in apple production per $m u$ is not significantly different between these two groups. Bagging is a dummy variable indicating whether the household used two-layered paper bags or not to cover the fruit during the growth period to protect them from environmental hazards. All the households used apple bags in 2014. We use the dummy variable to distinguish the bag costs. The result shows that higher percentage of members used double-layered bags than that of non-members.

\footnotetext{
${ }^{1}$ According to Huo, X., Liu, T., Liu, J., 2015. 2014 Annual Report on the Development of Chinese Apple Industry available., the average labour costs of apple production account for $45 \%$ and $46 \%$ of the total production costs in the Bohai Gulf Area and the Loss Plateau Area, respectively in 2014 (the original test is in Chinese and translated by the authors).
} 
Table 4.2 Descriptive statistics of variables used in the models

\begin{tabular}{|c|c|c|c|c|c|}
\hline & $\begin{array}{l}\text { Variable } \\
\text { Name }\end{array}$ & $\begin{array}{c}\text { Members } \\
\text { Mean (S.D. }{ }^{\mathrm{a}} \text { ) }\end{array}$ & $\begin{array}{l}\text { Non-members } \\
\text { Mean (S.D.) }\end{array}$ & $\begin{array}{l}\text { Difference } \\
\left(\text { S.E. }^{b}\right)\end{array}$ & $\begin{array}{l}\text { Full sample } \\
\text { Mean (S.D) }\end{array}$ \\
\hline \multirow{2}{*}{ Output } & yield & $\begin{array}{l}4140.70 \\
(2045.15)\end{array}$ & $\begin{array}{c}3851.78 \\
(2326.67)\end{array}$ & $\begin{array}{l}288.90 \\
(188.45)\end{array}$ & $\begin{array}{c}4028.16 \\
(2162.70)\end{array}$ \\
\hline & profit & $\begin{array}{c}7838.45 \\
(7308.46)\end{array}$ & $\begin{array}{c}7497.75 \\
(6671.75)\end{array}$ & $\begin{array}{c}340.70 \\
(621.17)\end{array}$ & $\begin{array}{c}7705.75 \\
(7063.01)\end{array}$ \\
\hline \multirow{8}{*}{ Physical asset } & fruit_year & $\begin{array}{l}17.59 \\
(7.1)\end{array}$ & $\begin{array}{l}18.01 \\
(7.28)\end{array}$ & $\begin{array}{l}-0.42 \\
(0.62)\end{array}$ & $\begin{array}{l}17.75 \\
(7.17)\end{array}$ \\
\hline & dwarf rootstock & $\begin{array}{c}0.11 \\
(0.31)\end{array}$ & $\begin{array}{c}0.07 \\
(0.26)\end{array}$ & $\begin{array}{c}0.04 \\
(0.02)\end{array}$ & $\begin{array}{c}0.10 \\
(0.26)\end{array}$ \\
\hline & land size & $\begin{array}{c}8.91 \\
(11.85)\end{array}$ & $\begin{array}{c}8.08 \\
(23.82)\end{array}$ & $\begin{array}{c}0.83 \\
(1.53)\end{array}$ & $\begin{array}{c}8.59 \\
(17.50)\end{array}$ \\
\hline & plots & $\begin{array}{l}3.84 \\
(2.25)\end{array}$ & $\begin{array}{l}3.50 \\
(1.63)\end{array}$ & $\begin{array}{l}0.34^{* *} \\
(0.177)\end{array}$ & $\begin{array}{l}3.71 \\
(2.04)\end{array}$ \\
\hline & specialization & $\begin{array}{c}0.83 \\
(0.23)\end{array}$ & $\begin{array}{c}0.85 \\
(0.22)\end{array}$ & $\begin{array}{l}-0.02 \\
(0.02)\end{array}$ & $\begin{array}{c}0.84 \\
(0.23)\end{array}$ \\
\hline & quality & $\begin{array}{c}0.84 \\
(0.17)\end{array}$ & $\begin{array}{c}0.82 \\
(0.17)\end{array}$ & $\begin{array}{c}0.01 \\
(0.01)\end{array}$ & $\begin{array}{c}0.83 \\
(0.17)\end{array}$ \\
\hline & income_2009 & $\begin{array}{c}36027.60 \\
(58970.04)\end{array}$ & $\begin{array}{c}29465.12 \\
(70345.06)\end{array}$ & $\begin{array}{c}6562.48 \\
(5554.59)\end{array}$ & $\begin{array}{c}33471.56 \\
(63660.92)\end{array}$ \\
\hline & non-farm & $\begin{array}{c}0.10 \\
(0.30) \\
\end{array}$ & $\begin{array}{c}0.12 \\
(0.33) \\
\end{array}$ & $\begin{array}{l}-0.02 \\
(0.03) \\
\end{array}$ & $\begin{array}{c}0.11 \\
(0.31) \\
\end{array}$ \\
\hline \multirow{5}{*}{ Human capital } & gender & $\begin{array}{l}0.99 \\
(0.12)\end{array}$ & $\begin{array}{c}0.97 \\
(0.17)\end{array}$ & $\begin{array}{l}0.02 \\
(0.01)\end{array}$ & $\begin{array}{c}0.98 \\
(0.14)\end{array}$ \\
\hline & age & $\begin{array}{l}52.00 \\
(7.98)\end{array}$ & $\begin{array}{l}52.12 \\
(9.78)\end{array}$ & $\begin{array}{l}-0.12 \\
(0.76)\end{array}$ & $\begin{array}{l}52.05 \\
(8.71)\end{array}$ \\
\hline & education & $\begin{array}{c}9.39 \\
(2.20)\end{array}$ & $\begin{array}{l}8.86 \\
(2.51)\end{array}$ & $\begin{array}{l}0.53^{* * * *} \\
(0.20)\end{array}$ & $\begin{array}{l}9.18 \\
(2.34)\end{array}$ \\
\hline & training & $\begin{array}{l}2.05 \\
(2.14)\end{array}$ & $\begin{array}{l}1.20 \\
(1.72)\end{array}$ & $\begin{array}{l}0.85^{* \pi * \pi} \\
(0.17)\end{array}$ & $\begin{array}{l}1.72 \\
(2.03)\end{array}$ \\
\hline & skill_level & $\begin{array}{r}2.25 \\
(0.68) \\
\end{array}$ & $\begin{array}{r}2.03 \\
(0.66) \\
\end{array}$ & $\begin{array}{l}0.22^{* \pi *} \\
(0.06) \\
\end{array}$ & $\begin{array}{c}2.16 \\
(0.68) \\
\end{array}$ \\
\hline \multirow[b]{2}{*}{ Social capital } & membership & $\begin{array}{l}1.00 \\
(0.00)\end{array}$ & $\begin{array}{l}0.00 \\
(0.00)\end{array}$ & $\begin{array}{l}1.00 \\
(0.00)\end{array}$ & $\begin{array}{c}0.61 \\
(0.49)\end{array}$ \\
\hline & village cadre & $\begin{array}{c}0.31 \\
(0.46) \\
\end{array}$ & $\begin{array}{c}0.19 \\
(0.39) \\
\end{array}$ & $\begin{array}{l}0.12^{* * * *} \\
(0.04)\end{array}$ & $\begin{array}{c}0.26 \\
(0.44) \\
\end{array}$ \\
\hline \multirow{7}{*}{ Variable inputs } & fertilizer & $\begin{array}{c}2177.17 \\
(1448.21)\end{array}$ & $\begin{array}{c}1986.10 \\
(1260.03)\end{array}$ & $\begin{array}{c}191.07 \\
(120.28)\end{array}$ & $\begin{array}{l}2102.75 \\
(1379.95)\end{array}$ \\
\hline & pesticide & $\begin{array}{c}460.94 \\
(320.18)\end{array}$ & $\begin{array}{l}463.50 \\
(304.81)\end{array}$ & $\begin{array}{l}-2.565 \\
(27.43)\end{array}$ & $\begin{array}{l}461.93 \\
(314.00)\end{array}$ \\
\hline & family labour & $\begin{array}{l}19.87 \\
(14.76)\end{array}$ & $\begin{array}{l}21.97 \\
(1.00)\end{array}$ & $\begin{array}{l}-2.10^{*} \\
(1.28)\end{array}$ & $\begin{array}{c}20.69 \\
(0.628)\end{array}$ \\
\hline & hired labour & $\begin{array}{l}10.64 \\
(9.14)\end{array}$ & $\begin{array}{c}8.89 \\
(10.44)\end{array}$ & $\begin{array}{l}1.74 \\
(0.84)\end{array}$ & $\begin{array}{l}9.95 \\
(0.41)\end{array}$ \\
\hline & total labour ${ }^{1}$ & $\begin{array}{c}30.5 \\
(16.66)\end{array}$ & $\begin{array}{c}30.85 \\
(17.53)\end{array}$ & $\begin{array}{l}-0.36 \\
(1.48)\end{array}$ & $\begin{array}{c}30.63 \\
(16.98)\end{array}$ \\
\hline & irrigation & $\begin{array}{l}2.88 \\
(3.11)\end{array}$ & $\begin{array}{l}2.60 \\
(2.83)\end{array}$ & $\begin{array}{c}0.28 \\
(0.26)\end{array}$ & $\begin{array}{l}2.77 \\
(3.00)\end{array}$ \\
\hline & bagging $^{2}$ & $\begin{array}{r}0.87 \\
(0.34) \\
\end{array}$ & $\begin{array}{r}0.81 \\
(0.39) \\
\end{array}$ & $\begin{array}{l}0.06^{*} \\
(0.03) \\
\end{array}$ & $\begin{array}{c}0.84 \\
(0.36) \\
\end{array}$ \\
\hline \multirow{5}{*}{$\begin{array}{l}\text { Local physical } \\
\text { environment }\end{array}$} & weather & $\begin{array}{l}0.82 \\
(0.39)\end{array}$ & $\begin{array}{l}0.79 \\
(0.41)\end{array}$ & $\begin{array}{c}0.03 \\
(0.03)\end{array}$ & $\begin{array}{c}0.80 \\
(0.40)\end{array}$ \\
\hline & loss & $\begin{array}{c}0.68 \\
(0.467)\end{array}$ & $\begin{array}{c}0.62 \\
(0.48)\end{array}$ & $\begin{array}{c}0.06 \\
(0.04)\end{array}$ & $\begin{array}{c}0.66 \\
(0.48)\end{array}$ \\
\hline & region & 0.55 & 0.51 & 0.04 & 0.53 \\
\hline & & $(0.50)$ & $(0.50)$ & $(0.04)$ & $(0.50)$ \\
\hline & distance & $\begin{array}{c}7.23 \\
(8.43)\end{array}$ & $\begin{array}{c}7.12 \\
(8.46)\end{array}$ & $\begin{array}{c}0.11 \\
(0.74)\end{array}$ & $\begin{array}{c}7.19 \\
(8.43)\end{array}$ \\
\hline \multirow{3}{*}{$\begin{array}{l}\text { Social } \\
\text { environment }\end{array}$} & test & $\begin{array}{c}0.65 \\
(0.46)\end{array}$ & $\begin{array}{c}0.70 \\
(0.46)\end{array}$ & $\begin{array}{l}-0.05 \\
(0.04)\end{array}$ & $\begin{array}{c}0.67 \\
(0.47)\end{array}$ \\
\hline & organization & $\begin{array}{c}1.89 \\
(1.68)\end{array}$ & $\begin{array}{c}1.75 \\
(1.56) \\
\end{array}$ & $\begin{array}{c}0.14 \\
(0.14) \\
\end{array}$ & $\begin{array}{c}1.84 \\
(1.63) \\
\end{array}$ \\
\hline & $\begin{array}{l}\text { Number of } \\
\text { observations }\end{array}$ & 336 & 215 & -- & 551 \\
\hline
\end{tabular}

Note: ${ }^{* * *},{ }^{* *}$ and ${ }^{*}$ denote the significance levels of $1 \%, 5 \%$ and $10 \%$, respectively. "a" denotes standard deviations. "b" denotes standard

\footnotetext{
${ }^{1}$ The total labour input is not one of the explanatory variables that are used for the explanation later.

${ }^{2}$ Bags here refer to the bags used to cover the fruit during the growth period to protect them from environmental hazards. All the households used bags in 2014 for apples. Four types of bags were used, viz. plastic bags, single-layer paper bag, doublelayer bags with two colours and double-layer bags with three colours (with the price ranking from low to high). We transformed the categorical variable into a dummy variable (whether the household used two-layer bags or not).
} 


\subsection{Estimation Results and Discussion}

First, we check the potential multicollinearity of explanatory variables on the basis of variance inflation factors (VIFs) of the two linear regression models and one linear probability model after using OLS to estimate these explanatory variables. For the yield equations, the highest VIF is 18.15 (average of 3.6). The two square terms (tree age and land size) contribute to the high VIF. Neglecting these two square terms, the average VIF will decrease to 1.33, and the highest VIF will decrease to 2.77. Similarly, for the profit equation the highest VIF will decrease to 2.95 (average of 1.34). For the membership regression model, the highest value of VIF is 7.92 (average of 1.92). The values are lower than the common chosen critical value of 10 (Spanos and McGuirk, 2002). Therefore, we can claim that these explanatory variables are not suspected of multicollinearity. The estimation results of ETRM are shown in Table 4.3.

The Wald test in the last row of Table 4.3 indicates that the null hypothesis of no correlation between the treatment-assignment errors and the outcome errors for the control and treatment groups (non-member and member groups) should be rejected. The values of $\rho$ are significant at the $10 \%$ and $5 \%$ levels, respectively. These findings support the premise that the cooperative membership is endogenous in both the yield and the profit equations.

\subsubsection{Cooperative membership}

The estimates of the factors of cooperative membership is shown in the column of Treatment Equation. Here we present the estimation results for the treatment equation for the yield equation. The estimation results of the treatment equation for profits can be found in Table A.4.1 in Appendix. Though the results are different with respect to magnitudes, they are similar in signs and significant levels.

The results show that physical assets play an important role in farmers' choice of membership. Land size has a nonlinear effect on cooperative membership. With the increase of the bearing area, farmers are more inclined to participate in the cooperative. When the area reaches more than $150 \mathrm{mu}$ or $10 \mathrm{Ha}$, the probability of participation declines with the increase in land size. Incomes from apple productions in 2009, apple quality and technical training have positive impacts on membership. The results are in line with our previous assumptions about these factors' impacts on the membership.

In addition, we find that the experience as a village cadre has positive effect on cooperative membership. Village cadres fulfil state tasks (Kung et al., 2009), and they are generally quick 
responders to the government's policy calls. Given the Chinese government's policy of supporting the development of cooperatives, village cadre are more likely to become a member at a cooperative.

Production losses caused by extreme weather are found to increases the probability that farmers become members. Extreme weather harms apple quality. Contrary to private traders, cooperatives usually buy blemished apples caused by bad weather. Finally, the more entertainment organizations a village has, the more probably for farmers to participate in cooperatives. Such organizations give villagers more opportunities to communicate with each other, which contributes to mutual trust and thus promotes cooperation among farmers. The estimation results are in line with our hypotheses. The significant effects of the extra variables for estimating the treatment equation are consistent with our previous hypothesis and provides evidence for their effectiveness as IVs. 
Table 4.3 Estimation results, endogenous treatment regression model

\begin{tabular}{|c|c|c|c|c|}
\hline & \multirow{2}{*}{$\begin{array}{l}\text { Variable } \\
\text { Name }\end{array}$} & \multicolumn{2}{|c|}{ Outcome equations } & \multirow{2}{*}{$\begin{array}{c}\text { Treatment equations } \\
\text { Cooperative membership } \\
\text { S.E. }\end{array}$} \\
\hline & & $\begin{array}{l}\log \text { Yield } \\
\text { S.E. }\end{array}$ & $\begin{array}{c}\log \text { Profits } \\
\text { S.E. }\end{array}$ & \\
\hline & fruit_year & $\begin{array}{l}0.05 \\
(0.02)\end{array}$ & $\begin{array}{c}0.00 \\
(0.02)\end{array}$ & -- \\
\hline & square_fy & $\begin{array}{l}-0.001^{* * *} \\
(0.00)\end{array}$ & $\begin{array}{c}0.00 \\
(0.00)\end{array}$ & -- \\
\hline & dwarf rootstock & $\begin{array}{l}0.05 \\
(0.07)\end{array}$ & $\begin{array}{c}0.04 \\
(0.10)\end{array}$ & -- \\
\hline & land size & $\begin{array}{l}-0.02^{* * * *} \\
(0.01)\end{array}$ & $-0.01^{*}$ & $\begin{array}{l}0.03^{* * *} \\
(0.01)\end{array}$ \\
\hline & $(\text { land size })^{2}$ & $0.0001^{* * * *}$ & 0.00 & $-0.0001^{* * * *}$ \\
\hline & (land s1ze) $)^{2}$ & $(0.00)$ & $(0.00)$ & $(0.00)$ \\
\hline & plots & $\begin{array}{l}-0.01 \\
(0.01)\end{array}$ & $\begin{array}{l}0.00 \\
(0.02)\end{array}$ & $\begin{array}{c}0.04 \\
(0.03)\end{array}$ \\
\hline & specialization & - & $\begin{array}{l}-0.24 \\
(0.18)\end{array}$ & $\begin{array}{l}-0.39 \\
(0.27)\end{array}$ \\
\hline & & & $1.22^{* * *}$ & $0.83^{* * *}$ \\
\hline & quality & -- & $(0.26)$ & $(0.39)$ \\
\hline & income_2009 $(\log )$ & $\begin{array}{l}0.03^{*} \\
(0.02)\end{array}$ & $\begin{array}{c}0.07^{* * * *} \\
(0.02)\end{array}$ & $\begin{array}{l}0.05^{* *} \\
(0.02)\end{array}$ \\
\hline & non-farm & $\begin{array}{l}-0.02 \\
(0.07)\end{array}$ & $\begin{array}{c}0.02 \\
(0.12)\end{array}$ & - \\
\hline & gender & $\begin{array}{c}0.01 \\
(0.19)\end{array}$ & $\begin{array}{l}-0.15 \\
(0.21)\end{array}$ & $\begin{array}{l}-0.38 \\
(0.42)\end{array}$ \\
\hline & age & 0.00 & 0.00 & 0.00 \\
\hline & & $\begin{array}{c}(0.00) \\
0.00\end{array}$ & $\begin{array}{l}(0.00) \\
-0.01\end{array}$ & $\begin{array}{c}(0.01) \\
0.03\end{array}$ \\
\hline & education & $(0.01)$ & $(0.02)$ & $(0.03)$ \\
\hline & training & -- & -- & $\begin{array}{l}0.10^{* \ldots+} \\
(0.04)\end{array}$ \\
\hline & skill level & $\begin{array}{c}0.03 \\
(0.04)\end{array}$ & $\begin{array}{c}0.04 \\
(0.05)\end{array}$ & -- \\
\hline & membership(M) & $\begin{array}{l}1.15 \\
(0.87)\end{array}$ & $\begin{array}{c}0.39 \\
(1.05)\end{array}$ & -- \\
\hline & village cadre & $\begin{array}{l}-0.10^{*} \\
(0.06)\end{array}$ & $\begin{array}{l}-0.11 \\
(0.09)\end{array}$ & $\begin{array}{l}0.26^{*} \\
(0.14)\end{array}$ \\
\hline \multirow{14}{*}{$\begin{array}{l}\text { Cross terms } \\
\text { of membership } \\
\text { and input } \\
\text { variables }\end{array}$} & ${ }^{\mathrm{a}} \mathbf{M}_{0} *$ (log_fertilizer) & $\begin{array}{c}0.04 \\
(0.08)\end{array}$ & $\begin{array}{c}0.11 \\
(0.10)\end{array}$ & -- \\
\hline & ${ }^{\mathrm{b}} \mathrm{M}_{1} *$ (log_fertilizer) & $\begin{array}{l}0.09^{* * * *} \\
(0.03)\end{array}$ & $\begin{array}{l}0.08^{* *} \\
(0.04)\end{array}$ & \\
\hline & $\mathrm{M}_{0} *\left(\log \_\right.$pesticide $)$ & $\begin{array}{l}0.17^{* \pi} \\
(0.07)\end{array}$ & $\begin{array}{c}0.12 \\
(0.08)\end{array}$ & -- \\
\hline & $\mathrm{M}_{1} *\left(\log \_\right.$pesticide $)$ & $\begin{array}{l}-0.06 \\
(0.05)\end{array}$ & $\begin{array}{c}0.05 \\
(0.07)\end{array}$ & \\
\hline & $\mathrm{M}_{0} *\left(\log \_\right.$hirelabour$)$ & $\begin{array}{c}0.07 \\
(0.05)\end{array}$ & $\begin{array}{l}0.08^{*} \\
(0.05)\end{array}$ & -- \\
\hline & $\mathrm{M}_{1} *\left(\log \_\right.$hirelabour$)$ & $\begin{array}{l}0.20^{* \pi *} \\
(0.04)\end{array}$ & $\begin{array}{l}0.13^{* * * *} \\
(0.04)\end{array}$ & \\
\hline & $\mathrm{M}_{0} *(\log$ familylabour$)$ & $\begin{array}{c}0.03 \\
(0.10)\end{array}$ & $\begin{array}{c}-0.02 \\
(0.10)\end{array}$ & -- \\
\hline & $\mathrm{M}_{1} *$ (log_familylabour) & $\begin{array}{c}0.07^{*} \\
(0.06)\end{array}$ & $\begin{array}{l}-0.09 \\
(0.07)\end{array}$ & \\
\hline & $\mathrm{M}_{0} *$ (irrigation) & $\begin{array}{c}0.01 \\
(0.02)\end{array}$ & $\begin{array}{l}-0.03 \\
(0.03)\end{array}$ & -- \\
\hline & $\mathrm{M}_{1} *$ (irrigation) & $\begin{array}{c}0.02 \\
(0.01)\end{array}$ & $\begin{array}{l}-0.03 \\
(0.02)\end{array}$ & \\
\hline & $\mathrm{M}_{0} *$ (bagging) & $\begin{array}{c}0.03 \\
(0.06)\end{array}$ & $\begin{array}{c}0.02 \\
(0.07)\end{array}$ & -- \\
\hline & $\mathrm{M}_{1} *$ (bagging) & $\begin{array}{c}0.02 \\
(0.04)\end{array}$ & $\begin{array}{c}-0.01 \\
(0.06)\end{array}$ & \\
\hline & weather & $\begin{array}{c}0.00 \\
(0.07)\end{array}$ & $\begin{array}{c}0.05 \\
(0.08)\end{array}$ & -- \\
\hline & loss & -- & -- & $\begin{array}{c}0.19^{*} \\
(0.12)\end{array}$ \\
\hline
\end{tabular}

1 We include the logarithm of incomes from apple productions in 2009 as one of the explanatory variables. Our data shows that 18 out of 528 households got non-positive incomes, accounting for $3 \%$ of the total households. We assign " 1 " to these zero values. Following Battese's idea (1997), we add a dummy variable to the equations such that efficient estimators are obtained using all observations with values of apple incomes to avoid bias. We found that the dummy variable is not significant in either the regression of yields or profits/mu. 


\begin{tabular}{|c|c|c|c|}
\hline \multirow{2}{*}{$\begin{array}{l}\text { Variable } \\
\text { Name }\end{array}$} & \multicolumn{2}{|c|}{ Outcome equations } & \multirow{2}{*}{$\begin{array}{c}\text { Treatment equations } \\
\text { Cooperative membership } \\
\text { S.E. }\end{array}$} \\
\hline & $\begin{array}{l}\log \text { Yield } \\
\text { S.E. }\end{array}$ & $\begin{array}{c}\log \text { Profits } \\
\text { S.E. }\end{array}$ & \\
\hline distance & -- & -- & $\begin{array}{c}0.00 \\
(0.01)\end{array}$ \\
\hline region & $\begin{array}{c}-0.26^{* * *} \\
(0.08)\end{array}$ & $\begin{array}{c}-0.35^{* * * *} \\
(0.11)\end{array}$ & $\begin{array}{c}0.13 \\
(0.13)\end{array}$ \\
\hline organisation & -- & -- & $\begin{array}{l}0.06^{*} \\
(0.04)\end{array}$ \\
\hline test & -- & -- & $\begin{array}{l}-0.15 \\
(0.12)\end{array}$ \\
\hline constant & $\begin{array}{l}5.72^{\text {**** }} \\
(0.84)\end{array}$ & $\begin{array}{l}6.19^{* * * *} \\
(1.02)\end{array}$ & $\begin{array}{c}-1.37 \\
(0.88)\end{array}$ \\
\hline$\rho$ & $\begin{array}{l}-0.50 \\
(0.24)\end{array}$ & $\begin{array}{l}0.46^{3 .} \\
(0.20)\end{array}$ & -- \\
\hline Wald $\chi^{2}$ & $2.69^{*}$ & $4.02^{* *}$ & -- \\
\hline No. of observations & 551 & 528 & 551 \\
\hline
\end{tabular}

Note: ${ }^{* * *},{ }^{* *}$ and ${ }^{*}$ denote the significance levels of $1 \%, 5 \%$ and $10 \%$, respectively.

"a" denotes the estimated coefficients for the group of non-members; "b" denotes the estimated coefficients for the group of members.

\subsubsection{Yield}

The first column of Outcome Equations in Table 4.3 presents the estimation results for apple yields. We can tell the different effects of input on two groups of farmers from the results for the cross terms of membership and input variables. Given the importance of the cross terms for our analysis, we will discuss them further in Section 6.4.

As expected, physical assets are important determinants of yields. Both the age of apple trees and land size have a nonlinear effect on yield. The estimated age at which trees give maximum yield is 25 years while apple farmers at $100 \mathrm{mu}$ are found to give the highest yields. The result reflects the fact that most Chinese farms are small in scale and most of them have not reached economies of scale. The income from apples in 2009 have a positive effect on the yield, which is in line with our hypothesis.

Few indicators of human capital or social capital has significant effect on the yield, except for village cadre variable. Its significant negative impact may be explained from the fact that village cadres may spend less time in apple production than other farmers. Instead, they may have relatively more other income resources, because of better social networks. The regional dummy is significant at $1 \%$ level, which indicates that controlling for other factors, apple farmers in Shaanxi have lower yields than farmers in Shandong.

\subsubsection{Profit}

The estimates of the determinants of profits from apple production are shown in Column 5 in Table 4.3. Because we use the logarithm of profits from apple production per $m u$ as one of 
our dependent variables in our analysis, we removed the 23 households with a negative profit from apple production in 2014 (accounting for $4.2 \%$ of 551 households). Finally, data of 528 farmers ${ }^{1}$ were used for analyzing profits/mu, including 322 member farmers (174 in Shaanxi and 148 in Shandong) and 206 non-member farmers (103 in Shaanxi and 103 in Shandong). In respect of the impact of physical asset on profits per unit area, we learn that with the increase of the land size, the profits/mu will decrease. The reverse relationship between land size and profits is in line with Ali and Deininger (2015). According to Fan and Chan - Kang (2005), the inverse relationship can be attributed to the differences in land use intensity, land fertility, and managerial factors. For Chinese smallholder farmers, the most important labor force is from the household members. With constraints of capital and labor supply, increasing the land size is likely to harm the profits because of inadequate investment. Particularly, Table A.4.2 shows that with the increase of land size, farmers tend to hire more labor and use less family labour. With the increasing cost of employing labor, the room for profit will decrease undoubtedly, given the homogeneous price level of apples to farmers.

The apple quality exerts a positive effect on the profits/mu at the $1 \%$ level. It is intuitively reasonable that the higher the quality of apples the farmer produces, the more profits the farmer can get due to securing comparatively better prices. Similarly, the incomes from apple production in 2009 have a significantly positive impact on the profits. Better access to cash and credit can increase the probability to adopt new technologies and increase inputs, which can possibly improve profits from the production. The results confirm our hypothesis.

None of the indicators of human capital or social capital has significant effect on the profits per unit area. This can be related to the attribute of apple production. Comparatively, apple production is more of capital-intensity than labour-intensity due to fertilizers and other input investment. From the coefficient of the regional dummy variable, we can learn that compared with farmers in Shandong Province, farmers in Shaanxi Province have both lower yields and profits from apples per unit area on average. The result implies that farmers in Shandong have a higher productivity than farmers in Shaanxi. Possible reasons can be

\footnotetext{
${ }^{1}$ According to Wicklin (2011), there are two common ways to handle negative values when one wants to log-transform the data. Solution 1 is to translate and then transform. The common technique is to add a constant value to the data prior to applying the log transform. Solution 2 is to handle negative values by marking them as missing values. Here we choose Solution 2 .
} 
multifaceted, for instance, differences in physical environment and orchard management skills and experience.

\subsubsection{Yields and profits: group specific effects of input use}

From the cross terms of the dummy variable for membership and the variables of various inputs shown in Table 4.3, we can learn the pathways how the different effects of the inputs on both yield/mu and profit/mu bring about for both the member and non-member group. The main findings are as follows.

Firstly, the application of fertilizers positively affects both the yield and profits per unit area for the member group, but has no significant effects on either yield or profit for the nonmember group. Secondly, inputs of hired labour and self-labour exert significantly positive impacts on members' yields, but no significant impact on non-members' yields. Furthermore, the input of hired labor has a bigger and more significant effect on the profit/mu for the member group than for the non-member group. In contrast, the coefficient of pesticide costs is significantly different from zero at the $1 \%$ level for non-members' yields, but insignificant for members'.

The results can be explained by the effects of cooperative service on apple farmers' production practices. As explained in the Conceptual Framework presented in Figure 1, cooperatives can improve farmers' access to both input and output markets, which may allow members to obtain inputs with cheaper prices and of better quality. This access can thereby lead to changes both in the quality and quantity of inputs used by farmers. Furthermore, cooperatives offer specific trainings, technical assistance and other extension services of production, which can influence the production practice of member farmers. For example, member farmers may apply specific kind of fertilizers at specific times during the apple growth period according to the suggestions or guides of the cooperative. This specific practice may lead to changes in both the quality and quantity of apple outputs.

Similarly, cooperatives also advise members to use different types of pesticides during production, mainly due to the specific requirements of pesticide practices determined by a certain production certification (e.g. organic products) or some buyers' stringent requirements of the pesticide residues on apples in response to the increasing food safety concern. These pesticides can usually be less toxic and thus probably less effective than traditional pesticides. Members, therefore, are probably inefficient in pesticide use. This notion may explain the insignificant effect of pesticides on the yield improvement for members. 
In summary, the services provided by the cooperative can make a difference both in the quality and quantity of the used inputs for apple production, which result in the difference in effectiveness and efficacy of inputs used. Hence, the outputs (yields and profits) are different between the two groups. Our previous assumptions have been confirmed by the results.

\subsubsection{Estimating treatment effects}

We estimate the treatment effects of membership on the yield $/ m u$ and the profits/mu from apple production by measuring ATET, ATUT and ATE, which are presented in Table 4.4. More detailed results of treatment effects can be found in Table A.4.3 and Table A.4.4 in Appendix. We can learn that ATET (in percentage) for the yield/mu is $7.84 \%$, which means that if the members had not participated in the cooperatives, their average yield/mu would have been $7.84 \%$ lower, keeping other variables constant. ATEU is $5.50 \%$, which means that non-member farmers could have gained an increase of $5.50 \%$ in the yield/mu had they participated in the cooperatives, keeping other variables constant. ATE is 3.51\%, meaning the predicted yield $/ m u$ of the treatment group (member farmers) is $3.51 \%$ more than that of the control group (non-member farmers) on average.

Table 4.4 Treatment effect of cooperative membership on apple yield/mu and profits/mu

\begin{tabular}{|c|c|c|c|c|c|c|}
\hline & \multicolumn{6}{|c|}{ Treatment effect Contrast (members vs non-members) } \\
\hline & ATET & ATET in \% & ATEU & ATEU in \% & ATE & ATE in $\%$ \\
\hline $\mathrm{yield} / m u$ & $0.57^{* *}$ & $7.84^{* *}$ & $0.54^{*}$ & $5.50^{*}$ & $0.56^{* *}$ & $3.51^{* *}$ \\
\hline profits/mu & -0.44 & -0.23 & -0.46 & -3.30 & -0.45 & 1.29 \\
\hline
\end{tabular}

Note: ${ }^{* * *},{ }^{* *}$ and ${ }^{*}$ denote the significance levels of $1 \%, 5 \%$ and $10 \%$, respectively.

As for the treatment effects on the profits/mu, however, we can learn that neither ATET, ATEU nor ATE is statistically significant. Therefore, we can conclude that the treatment effect of membership on the profits/mu from apple production is not different from zero.

The significantly positive treatment effect of membership on the apple yield can be explained through the difference between members and non-members in the effectiveness and efficacy of input used for production, which has been explained in the previous section.

The possible reason for the insignificant treatment effect of membership on the profits from apple production lies in the difference between the value of extra outputs and the extra cost of inputs. We can generally conclude that member farmers make more investment in inputs than 
non-members from Table 4.2, especially in fertilizers and hired labour. With the increasing prices of fertilizers, pesticides and other inputs in the domestic market, namely the labour costs, the gained profits from the extra yields may not cover the extra input costs. Therefore, even though the members have a higher average yield/mu than non-members, their profit from apple production per $m u$ is not significantly different from their counterparts.

\subsubsection{Robustness checks}

As a robustness check, we estimate the determinants of yields and profits by using ETRM without cross terms of membership and input variables (Table A.4.5) and 2SLS (Table A.4.6), respectively.

The estimation coefficients of membership by using ETRM without cross terms are its ATE on yields and profits, respectively. We learn that the ATE estimate of membership on yields is 0.61 , which is significantly different from zero. However, the ATE estimate of membership on profits is -0.49 , which is not statistically significant. The results are essentially the same as the ones produced by ETRM with cross terms. Furthermore, the other coefficient estimates also have similar signs and significant levels.

Compared with the ETRM estimates, we find that the 2SLS coefficient estimates have similar signs and effects but are less efficient. This is also reflected in a smaller number of statistically significant parameters in the 2SLS compared to the ETRM. The results of the Durbin-Wu-Hausman test for endogeneity of cooperative membership in the 2SLS are in line with the statistically significant correlation coefficient estimated by the ETRM presented in the bottom row of Table 4.4.

For the robustness check of the treatment effect, we also estimate the treatment effects of membership with propensity score match method (PSM, Table A.4.7). By comparing the results produced by PSM and ETRM, we find that the coefficients are similar in significant levels, but are very different in magnitudes - the estimated ATE and ATET by PSM are way smaller than the ones estimated by ETRM. Note that PSM only control for observable heterogeneity. Neglecting the unobservable results in underestimated treatment effects, which gives ETRM a comparative advantage. But the conclusions that we draw from the PSM are in line with the ones from the ETRM. 


\subsection{Conclusion and Discussion}

To further explore the answer to the question how agricultural cooperatives affect farmers' welfare, we have analyzed the effect of cooperative membership on the yield and the profits from apple production. We find that although cooperative membership has significantly positive treatment effects on the apple yield, it has no significant treatment effect on the profits. The empirical analysis is based on the field survey data of 551 apple farm households in Shaanxi and Shandong, China.

Using ETRM approach, we examine the pathways through which cooperative membership produces differences between the member and non-member groups in yields and profits. We find that distinctions both in the use levels and productivities of fertilizers and hired labours input mainly contribute to the differences.

Due to the production trainings and other services provided by the cooperatives, on the one hand, the two groups can have differences in both effectiveness and efficacy of inputs use. Benefited (from the training) members can have higher yields than non-members in general. On the other hand, members tend to invest more on inputs than non-members. With the increasing labour prices and other inputs, the gains from the extra yields do not cover the extra costs. Therefore, even though the members have a higher average apple yield than nonmembers, their profits from apple production per $m u$ is not significantly different from their counterparts.

Owing to data limitations, we analyze this question mainly from the input aspect, without considering the external market environment. For the same reason, we estimate the treatment effect of membership on the yield and profits per unit area by comparing the member and non-member groups based on the cross-sectional data. If panel data were available, we could not only control for farmer-specific factors that affects both dependent and explanatory variables, but allow to compare ex-ante with ex-post (participating in cooperatives) among farmers to gain a deeper insight into the treatment effects and the corresponding reasons. Most of the existing research indicates that the cooperative exerts a positive effect on farmer incomes (Sauer, et al., 2012, Verhofstadt and Maertens, 2014b, Ma and Abdulai, 2016). Our research puts a question mark to this statement. The Chinese government has been implementing policies to develop modern agricultural sector by promoting farmers to participate in farmer cooperatives and to foster other new types of agricultural business entities since 2012. The conclusion from the paper suggests a negative side-effect of this 
policy and makes us ponder over the problem. Meanwhile, our conclusion brings about other further questions: since cooperatives cannot increase farmers' profits effectively, what is the rationality for farmers' participation and continuation in cooperatives? Can Chinese cooperatives develop sustainably? Given the effect of cooperatives on farmers' production practices, especially the use of fertilizers, further research may focus on the impacts of policies promoting farmers' cooperative and the related policies on environmental and food quality issues. 


\section{References}

Abebaw, D., Haile, M. G., 2013. The impact of cooperatives on agricultural technology adoption: Empirical evidence from Ethiopia, Food Policy. 38, 82-91.

Addai, K. N., Owusu, V., Danso-Abbeam, G., 2014. Effects of farmer-Based-organization on the technical efficiency of maize farmers across Various Agro-Ecological Zones of Ghana, Journal of Economics and Development Studies. 2, 141-161.

Adhikari, K. P., Goldey, P., 2010. Social Capital and its "Downside": The Impact on Sustainability of Induced Community-Based Organizations in Nepal, World Development. 38, 184-194.

Ali, D. A., Deininger, K., 2015. Is there a farm size-productivity relationship in African agriculture? Evidence from Rwanda, Land Economics. 91, 317-343.

Angrist, J. D., 2010. Treatment Effect, in S. N. Durlauf and L. E. Blume eds., Microeconometrics. Palgrave Macmillan UK, London.

Chambers, R. G., Foster, W. E., 1983. Participation in the farmer-owned reserve program: a discrete choice model, American Journal of Agricultural Economics. 65, 120-124.

Crespo, J., Réquier-Desjardins, D., Vicente, J., 2014. Why can collective action fail in Local Agri-food Systems? A social network analysis of cheese producers in Aculco, Mexico, Food Policy. 46, 165-177.

Deb, P., Trivedi, P. K., 2006. Maximum simulated likelihood estimation of a negative binomial regression model with multinomial endogenous treatment, The Stata Journal. 6, 246-255.

Debertin, D. L., 1986. Agricultural production economics. Pearson Education, New Jersey, USA.

Fan, S., Chan - Kang, C., 2005. Is small beautiful? Farm size, productivity, and poverty in Asian agriculture, Agricultural Economics. 32, 135-146.

Fischer, E., Qaim, M., 2014. Smallholder Farmers and Collective Action: What Determines the Intensity of Participation?, Journal of Agricultural Economics, 1-20.

Gerber, A., 1998. Estimating the effect of campaign spending on senate election outcomes using instrumental variables, American Political Science Review. 92, 401-411.

Grootaert, C., 1999. Social capital, household welfare, and poverty in Indonesia, World bank policy research working paper.

Heckman, J. J., 1979. Sample Selection Bias as a Specification Error, Econometrica: Journal of the Econometric Society, 153-161.

Hu, J., 2012. Firmly march on the path of socialism with Chinese characteristics and strive to complete the building of a moderately prosperous society in all respects, People Daily. Xinhua Agency, Beijing.

Huo, X., Liu, T., Liu, J., 2015. 2014 Annual Report on the Development of Chinese Apple Industry available. IFAD, 2013. Smallholders, food security and the environment, available.

Ito, J., Bao, Z. S., Su, Q., 2012. Distributional effects of agricultural cooperatives in China: Exclusion of smallholders and potential gains on participation, Food Policy. 37, 700-709.

Kabunga, N. S., Dubois, T., Qaim, M., 2012. Yield effects of tissue culture bananas in Kenya: accounting for selection bias and the role of complementary inputs, Journal of Agricultural Economics. 63, 444-464.

Lipton, M., 2009. Land reform in developing countries: Property rights and property wrongs. Routledge.

Ma, W., Abdulai, A., 2016. Does cooperative membership improve household welfare? Evidence from apple farmers in China, Food Policy. 58, 94-102.

Marini, R. P., Barden, J. A., Cline, J. A., Perry, R. L., Robinson, T., 2002. Effect of Apple Rootstocks on AverageGala'Fruit Weight at Four Locations after Adjusting for Crop Load, Journal of the American Society for Horticultural Science. 127, 749-753.

Markelova, H., Meinzen-Dick, R., Hellin, J., Dohrn, S., 2009. Collective action for smallholder market access, Food policy. 34, 1-7.

Otsuka, K., Evenson, R., Pingali, P., 2007. Chapter 51 Efficiency and Equity Effects of Land Markets, Handbook of Agricultural Economics. Elsevier.

Sauer, J., Gorton, M., White, J., 2012. Marketing, cooperatives and price heterogeneity: evidence from the CIS dairy sector, Agricultural Economics. 43, 165-177.

Schultz, T. W., Schultz, T. W., 1982. Investing in people: The economics of population quality. Univ of California Press.

Spanos, A., McGuirk, A., 2002. The problem of near-multicollinearity revisited: erratic vs systematic volatility, Journal of Econometrics. 108, 365-393.

Tan, S., Heerink, N., Kruseman, G., Qu, F., 2008. Do fragmented landholdings have higher production costs? Evidence from rice farmers in Northeastern Jiangxi province, PR China, China Economic Review. 19 347-358.

Thorp, R., Stewart, F., Heyer, A., 2005. When and how far is group formation a route out of chronic poverty?, World development. 33, 907-920. 
Treder, W., Mika, A., Krzewinska, D., 2010. Relations between tree age, fruit load and mean fruit weight, Journal of Fruit and Ornamental Plant Research. 18, 139-149.

Uphoff, N., Wijayaratna, C. M., 2000. Demonstrated benefits from social capital: the productivity of farmer organizations in Gal Oya, Sri Lanka, World Development. 28, 1875-1890.

Verhofstadt, E., Maertens, M., 2014a. Can Agricultural Cooperatives Reduce Poverty? Heterogeneous Impact of Cooperative Membership on Farmers' Welfare in Rwanda, Applied Economic Perspectives and Policy, 1-21.

Verhofstadt, E., Maertens, M., 2014b. Smallholder cooperatives and agricultural performance in Rwanda: do organizational differences matter?, Agricultural Economics. 45, 39-52.

Wollni, M., Zeller, M., 2007. Do farmers benefit from participating in specialty markets and cooperatives? The case of coffee marketing in Costa Rica, Agricultural Economics. 37, 243-248. 


\section{Appendix 4.1}

Table A.4.1 Estimation of treatment equation for the model of profits/mu

\begin{tabular}{lc}
\hline Variable Name & Coefficients \\
\hline land size & $0.04^{* * *}$ \\
$(\text { land size })^{2}$ & $-0.0001^{* * *}$ \\
specialization & $-0.45^{*}$ \\
quality & 0.52 \\
income_2009(log) & 0.03 \\
non-farm & -0.05 \\
\hline gender & -0.33 \\
age & 0.00 \\
education & 0.03 \\
training & $0.12^{* * *}$ \\
skill level & $0.28^{* * *}$ \\
village cadre & $0.26^{*}$ \\
\hline loss & 0.16 \\
region & 0.02 \\
constant & -1.14 \\
\hline No. of observations & 528 \\
\hline Note: & \\
\hline
\end{tabular}

Note: $\quad{ }^{* * *},{ }^{* *}$ and ${ }^{*}$ denote the significance levels of $1 \%, 5 \%$ and $10 \%$, respectively.

\section{Appendix 4.2}

Table A.4.2 Correlation of input with land size

\begin{tabular}{lcc}
\hline Input variables & Correlation & P-value \\
\hline fertilizer & 0.01 & 0.77 \\
pesticide & 0.07 & 0.11 \\
hired labour & 0.39 & $0.00^{* * *}$ \\
family labour & -0.19 & $0.00^{* * *}$ \\
total labour & 0.06 & 0.19 \\
irrigation & 0.02 & 0.58 \\
\hline
\end{tabular}

Note: $\quad{ }^{* * *},{ }^{* *}$ and ${ }^{*}$ denote the significance levels of $1 \%, 5 \%$ and $10 \%$, respectively. 


\section{Appendix 4.3}

Table A.4.3 Average treatment effect of cooperative membership on yield

\begin{tabular}{lcccc}
\hline & \multicolumn{4}{c}{ Membership decision } \\
\cline { 2 - 5 } Farmer subsample & \multicolumn{2}{c}{ Participation (Treatment=1) } & \multicolumn{2}{c}{ Non-participation (Treatment=0) } \\
\cline { 2 - 5 } Members & \#Mean yield $/ \mathrm{mu}^{1}$ & S.E. & "Mean yield $/ \mathrm{mu}^{2}$ & S.E. \\
Non-members & 8.18 & 0.02 & 8.10 & 0.02 \\
Difference in \% & 8.10 & 0.03 & 8.05 & 0.02 \\
\hline
\end{tabular}

Note: ${ }^{* * *},{ }^{* *}$ and ${ }^{*}$ denote the significance levels of $1 \%, 5 \%$ and $10 \%$, respectively.

S.E. stands for standard errors.

\#The yield/mu shown are predictions based on the coefficients estimated with the endogenous treatment regression model (ETRM). As the dependent variables in ETRM outcome equations are the logarithms of yield/mu and profits/mu respectively, the predictions are also given in log forms. Converting the means back to original numbers would lead to inaccuracies, due to the inequality of arithmetic and geometric means (AM-GM inequality) (Kabunga, et al., 2012).

\section{Appendix 4.4}

Table A.4.4 Average treatment effect of cooperative membership on profits/mu from apple production

\begin{tabular}{|c|c|c|c|c|}
\hline \multirow[b]{3}{*}{ Farmer subsample } & \multicolumn{4}{|c|}{ Membership decision } \\
\hline & \multicolumn{2}{|c|}{ Participation $($ Treatment $=1)$} & \multicolumn{2}{|c|}{ No-participation $($ Treatment $=0)$} \\
\hline & ${ }^{\#}$ Mean profits $/ m u^{4}$ & S.E. & ${ }^{\#}$ Mean profits $/ m u^{5}$ & S.E. \\
\hline Members & 8.75 & 0.02 & 8.60 & 0.02 \\
\hline Non-members & 8.75 & 0.03 & 8.64 & 0.03 \\
\hline Difference in $\%$ & $-0.23 \%$ & 0.04 & $-3.30 \%^{6}$ & 0.04 \\
\hline
\end{tabular}

Note: S.E. denotes standard errors.

\# Please check the note in Table A.4.5.

${ }^{* * * * * *}$ and ${ }^{*}$ denote the significance levels of $1 \%, 5 \%$ and $10 \%$, respectively.

\footnotetext{
${ }^{1}$ The mean yield $/ m u$ when the treatment is received.

2 The mean yield $/ m u$ when the treatment is not received.

${ }^{3} 5.33 \%$ is the average treatment effect of yield/mu on the untreated group (non-member farmers) in percentage.

${ }^{4}$ The mean net incomes/mu when the treatment is received.

${ }^{5}$ The mean net incomes/mu when the treatment is not received.

${ }^{6}-3.01 \%$ is the average treatment effect of profits/mu on the untreated group (non-member farmers) in percentage.
} 


\section{Appendix 4.5}

Table A.4.5 Estimation results, endogenous treatment regression model (without cross terms)

\begin{tabular}{|c|c|c|c|}
\hline \multirow{2}{*}{$\begin{array}{l}\text { Variable } \\
\text { Name }\end{array}$} & \multicolumn{2}{|c|}{ Outcome equations } & \multirow{2}{*}{$\begin{array}{c}\text { Treatment equations } \\
\text { Coefficients (membership) } \\
\text { (Standard Errors). }\end{array}$} \\
\hline & $\begin{array}{l}\text { Coefficients (log yield) } \\
\text { (Standard Errors). }\end{array}$ & $\begin{array}{l}\text { Coefficients (log profits) } \\
\text { (Standard Errors). }\end{array}$ & \\
\hline fruit_year & $\begin{array}{l}0.05 \\
(0.02)\end{array}$ & $\begin{array}{c}0.01 \\
(0.02)\end{array}$ & -- \\
\hline square_fy & $\begin{array}{c}-0.001^{k *} \\
(0.00)\end{array}$ & $\begin{array}{l}0.00 \\
(0.00)\end{array}$ & -- \\
\hline dwarf rootstock & $\begin{array}{c}0.05 \\
(0.09)\end{array}$ & $\begin{array}{c}0.03 \\
(0.11)\end{array}$ & -- \\
\hline land size & $\begin{array}{c}-0.02^{* * * * *} \\
(0.00)\end{array}$ & $\begin{array}{l}-0.01^{*} \\
(0.01)\end{array}$ & $\begin{array}{l}0.03^{* * *} \\
(0.01)\end{array}$ \\
\hline$(\text { land size })^{2}$ & $\begin{array}{l}0.0001^{* * * *} \\
(0.00)\end{array}$ & $\begin{array}{c}0.00 \\
(0.00)\end{array}$ & $\begin{array}{l}-0.0001^{* * * *} \\
(0.00)\end{array}$ \\
\hline plots & $\begin{array}{l}-0.01 \\
(0.01)\end{array}$ & $\begin{array}{l}0.00 \\
(0.02)\end{array}$ & $\begin{array}{c}0.04 \\
(0.03)\end{array}$ \\
\hline specialization & -- & $\begin{array}{l}-0.24 \\
(0.17)\end{array}$ & $\begin{array}{l}-0.39 \\
(0.26)\end{array}$ \\
\hline quality & -- & $\begin{array}{l}1.23^{* * * *} \\
(0.23)\end{array}$ & $\begin{array}{l}0.86^{* *} \\
(0.32)\end{array}$ \\
\hline income_2009 (log) & $\begin{array}{l}0.03^{* *} \\
(0.01)\end{array}$ & $\begin{array}{l}0.07^{* * * *} \\
(0.02)\end{array}$ & $\begin{array}{l}0.05^{* *} \\
(0.02)\end{array}$ \\
\hline non-farm & $\begin{array}{l}-0.01 \\
(0.08)\end{array}$ & $\begin{array}{c}0.02 \\
(0.10)\end{array}$ & -- \\
\hline gender & $\begin{array}{c}0.04 \\
(0.19)\end{array}$ & $\begin{array}{l}-0.15 \\
(0.24)\end{array}$ & $\begin{array}{l}-0.39 \\
(0.39)\end{array}$ \\
\hline age & $\begin{array}{l}0.00 \\
(0.00)\end{array}$ & $\begin{array}{l}0.00 \\
(0.00)\end{array}$ & $\begin{array}{c}0.00 \\
(0.01)\end{array}$ \\
\hline education & $\begin{array}{c}0.00 \\
(0.01)\end{array}$ & $\begin{array}{c}0.00 \\
(0.02)\end{array}$ & $\begin{array}{c}0.03 \\
(0.03)\end{array}$ \\
\hline training & -- & -- & $\begin{array}{l}0.10 \\
(0.03)\end{array}$ \\
\hline skill level & $\begin{array}{c}0.02 \\
(0.04)\end{array}$ & $\begin{array}{c}0.04 \\
(0.05)\end{array}$ & -- \\
\hline membership(M) & $\begin{array}{l}0.61^{\text {**** }} \\
(0.19)\end{array}$ & $\begin{array}{l}-0.49 \\
(0.25)\end{array}$ & -- \\
\hline village cadre & $\begin{array}{l}-0.10^{*} \\
(0.06)\end{array}$ & $\begin{array}{l}-0.11 \\
(0.09)\end{array}$ & $\begin{array}{l}0.26^{*} \\
(0.14)\end{array}$ \\
\hline log_fertilizer & $\begin{array}{l}0.07^{\text {**3 }} \\
(0.04)\end{array}$ & $\begin{array}{l}0.09^{*} \\
(0.04)\end{array}$ & \\
\hline log_pesticide & $\begin{array}{l}0.05 \\
(0.03)\end{array}$ & $\begin{array}{c}0.08^{*} \\
(0.04)\end{array}$ & \\
\hline log_hirelabour & $\begin{array}{l}0.15^{* * *} \\
(0.02)\end{array}$ & $\begin{array}{l}0.11^{* * *} \\
(0.03)\end{array}$ & -- \\
\hline log_famlylabour & $\begin{array}{c}0.05 \\
(0.04)\end{array}$ & $\begin{array}{l}-0.06 \\
(0.05)\end{array}$ & -- \\
\hline irrigation & $\begin{array}{c}0.01 \\
(0.01)\end{array}$ & $\begin{array}{l}-0.03 \\
(0.02)\end{array}$ & \\
\hline bagging & $\begin{array}{c}0.02 \\
(0.04) \\
\end{array}$ & $\begin{array}{c}0.01 \\
(0.05) \\
\end{array}$ & \\
\hline weather & $\begin{array}{l}-0.01 \\
(0.06)\end{array}$ & $\begin{array}{c}0.05 \\
(0.08)\end{array}$ & -- \\
\hline loss & -- & - & $\begin{array}{l}0.19^{*} \\
(0.11)\end{array}$ \\
\hline distance & -- & -- & $\begin{array}{c}0.00 \\
(0.01)\end{array}$ \\
\hline region & $\begin{array}{c}-0.26^{* * * *} \\
(0.08) \\
\end{array}$ & $\begin{array}{c}-0.35^{* * * *} \\
(0.11) \\
\end{array}$ & $\begin{array}{c}0.14 \\
(0.13) \\
\end{array}$ \\
\hline organisation & - & -- & $\begin{array}{l}0.06^{*} \\
(0.04)\end{array}$ \\
\hline test & -- & -- & $\begin{array}{l}-0.14 \\
(0.12) \\
\end{array}$ \\
\hline constant & $\begin{array}{l}6.02^{* * * *} \\
(0.48)\end{array}$ & $\begin{array}{l}6.66^{* * * *} \\
(0.68)\end{array}$ & $\begin{array}{l}-1.39^{*} \\
(0.79)\end{array}$ \\
\hline$\rho$ & $\begin{array}{l}-0.53^{\text {\%*? }} \\
(0.15)\end{array}$ & $\begin{array}{l}0.48^{\text {*3. }} \\
(0.17)\end{array}$ & -- \\
\hline Wald $\chi^{2}$ & $4.33^{* *}$ & $4.52^{* *}$ & -- \\
\hline No. of observations & 551 & 528 & 551 \\
\hline
\end{tabular}




\section{Appendix 4.6}

Table A.4.6 2SLS regression results

\begin{tabular}{|c|c|c|}
\hline \multirow{2}{*}{$\begin{array}{l}\text { Variable } \\
\text { Name }\end{array}$} & \multicolumn{2}{|c|}{ Outcome equations } \\
\hline & $\begin{array}{l}\text { Coefficients (log yield) } \\
\text { Standard Deviation }\end{array}$ & $\begin{array}{l}\text { Coefficients (log profits) } \\
\text { Standard Deviation }\end{array}$ \\
\hline fruit_year & $\begin{array}{l}0.05 \\
(0.02)\end{array}$ & $\begin{array}{l}0.00 \\
(0.02)\end{array}$ \\
\hline square_fy & $\begin{array}{c}-0.001^{* * * *} \\
(0.00)\end{array}$ & $\begin{array}{c}0.00 \\
(0.00)\end{array}$ \\
\hline dwarf rootstock & $\begin{array}{l}0.01 \\
(0.11)\end{array}$ & $\begin{array}{l}0.07 \\
(0.13)\end{array}$ \\
\hline land size & $\begin{array}{c}-0.02^{* * * *} \\
(0.01)\end{array}$ & $\begin{array}{l}-0.01 \\
(0.01)\end{array}$ \\
\hline$(\text { land size })^{2}$ & $\begin{array}{l}0.0001^{* * * *} \\
(0.00)\end{array}$ & $\begin{array}{c}0.00 \\
(0.00)\end{array}$ \\
\hline plots & $\begin{array}{l}-0.01 \\
(0.02)\end{array}$ & $\begin{array}{l}0.01 \\
(0.02)\end{array}$ \\
\hline specialization & -- & $\begin{array}{l}-0.21 \\
(0.18)\end{array}$ \\
\hline quality & -- & $\begin{array}{l}1.22^{* * * *} \\
(0.25)\end{array}$ \\
\hline income_2009 (log) & $\begin{array}{c}0.02 \\
(0.02)\end{array}$ & $\begin{array}{l}0.08^{* * * *} \\
(0.02)\end{array}$ \\
\hline non-farm & $\begin{array}{c}0.03 \\
(0.08) \\
\end{array}$ & $\begin{array}{l}-0.01 \\
(0.10) \\
\end{array}$ \\
\hline gender & $\begin{array}{l}0.13 \\
(0.23)\end{array}$ & $\begin{array}{l}-0.24 \\
(0.28)\end{array}$ \\
\hline age & $\begin{array}{c}0.00 \\
(0.00)\end{array}$ & $\begin{array}{l}0.00 \\
(0.00)\end{array}$ \\
\hline education & $\begin{array}{l}0.00 \\
(0.01)\end{array}$ & $\begin{array}{c}0.00 \\
(0.02)\end{array}$ \\
\hline skill level & $\begin{array}{l}-0.05 \\
(0.06)\end{array}$ & $\begin{array}{c}0.12 \\
(0.08)\end{array}$ \\
\hline membership(M) & $\begin{array}{l}0.90^{* * *} \\
(0.43)\end{array}$ & $\begin{array}{l}-0.82 \\
(0.58)\end{array}$ \\
\hline village cadre & $\begin{array}{l}-0.13 \\
(0.08)\end{array}$ & $\begin{array}{l}-0.07 \\
(0.11)\end{array}$ \\
\hline log_fertilizer & $\begin{array}{l}0.06 \\
(0.04)\end{array}$ & $\begin{array}{l}0.09^{*} \\
(0.05)\end{array}$ \\
\hline log_pesticide & $\begin{array}{c}0.04 \\
(0.04)\end{array}$ & $\begin{array}{l}0.10^{*} \\
(0.05)\end{array}$ \\
\hline log_familylabour & $\begin{array}{l}0.06 \\
(0.05)\end{array}$ & $\begin{array}{l}-0.07 \\
(0.06)\end{array}$ \\
\hline log_hirelabour & $\begin{array}{l}0.13^{* * *} \\
(0.03)\end{array}$ & $\begin{array}{l}0.14^{* * * *} \\
(0.04)\end{array}$ \\
\hline irrigation & $\begin{array}{l}-0.01 \\
(0.02)\end{array}$ & $\begin{array}{l}-0.02 \\
(0.02)\end{array}$ \\
\hline bagging & $\begin{array}{l}-0.01 \\
(0.05)\end{array}$ & $\begin{array}{c}0.04 \\
(0.06)\end{array}$ \\
\hline weather & $\begin{array}{l}-0.04 \\
(0.08)\end{array}$ & $\begin{array}{l}0.08 \\
(0.10)\end{array}$ \\
\hline region & $\begin{array}{c}-0.33^{* * *} \\
(0.10)\end{array}$ & $\begin{array}{l}-0.30^{*} \\
(0.13)\end{array}$ \\
\hline constant & $\begin{array}{l}6.25^{* * *} \\
(0.57)\end{array}$ & $\begin{array}{l}6.37^{* * * *} \\
(0.76)\end{array}$ \\
\hline$\chi^{2}$ (Durbin) & $4.99^{* *}$ & $3.00^{*}$ \\
\hline F (Wu-Hausman) & $4.81^{* *}$ & $3.00^{*}$ \\
\hline No. of observations & 551 & 528 \\
\hline
\end{tabular}




\section{Appendix 4.7}

Table A.4.7 Treatment effect of cooperative membership on apple yield/mu and profits/mu (estimated by PSM)

\begin{tabular}{llc}
\hline & Treatment effect Contrast (members vs non-members) \\
\hline ATET & ATE \\
\hline yield $/ m u$ & $0.14^{* *}$ & $0.13^{* *}$ \\
profits $/ m u$ & -0.07 & 0.02 \\
\hline
\end{tabular}

Note: ${ }^{* * *}, * *$ and ${ }^{*}$ denote the significance levels of $1 \%, 5 \%$ and $10 \%$, respectively. 



\title{
5. Cooperative member commitment, trust and social pressure: The role of members' participation in the decision-making ${ }^{1}$
}

\begin{abstract}
Member commitment concerns cooperatives' viability and success. Though separate research about the antecedents of member commitment has been done, systematic research into member commitment within agricultural cooperatives is rare, especially the way how these antecedents (or correlates) affect member commitment. Using a sample of 391 farmer cooperative members in China, this study investigates whether trust in the cooperative leadership and social pressure affect cooperative member commitment and the mechanism by which these two antecedents exert effect on member commitment by employing structural equation models. Our study finds that both trust and social pressure are positively associated with three components of member commitment - affective commitment, continuance commitment and normative commitment in a direct way. Furthermore, trust influences affective commitment indirectly via the partial mediator of member participation. Generally, these findings provide an empirical evidence on the important role of the cooperative chairperson in Chinese cooperatives and on the influence of social pressure with Chinese characteristics in maintaining cooperative membership.
\end{abstract}

Key words

Member commitment, trust, social pressure, member participation

\footnotetext{
${ }^{1}$ Unpublished paper by Jinghui Hao, Jos Bijman and Wim Heijman.
} 


\subsection{Introduction}

Organizational commitment reduces withdrawal cognition and turnover behaviors and increases positive performances of both employees and organizations (Meyer et al., 2002). In the cooperative context, member commitment concerns a cooperative's viability. Particularly at an early stage of collective action, member commitment is an essential input for organizations to succeed (Tadesse and Kassie, 2017). Member commitment maintains membership and trade volumes even when transactions become more unstable and opportunities to reorganize show up (Fulton, 1999). Lacking member commitment can lead to the demise of the cooperative. However, not much attention has been paid to research about member commitment in cooperative settings.

Member commitment has not been uniformly conceptualized (Klein et al., 2009). Mowday et al. (1979, p.226) defined organization commitment as "the relative strength of an individual's identification with and involvement in a particular organization". Following the more recent organizational commitment literature (Meyer, et al., 2002; Solinger et al., 2008), member commitment is defined as an attitude towards the organization or towards a behaviour involving the organization (Cechin et al., 2013).

Important advances have been made regarding distinguishing the mind-sets leading to commitment. We can gain some insights about the antecedents and correlates of member commitment in cooperative settings from both quantitative and qualitative studies of commitment. The antecedents of member commitment include economic and social factors, such as the price of the product or service provided by the cooperative and trust (Fulton and Giannakas, 2001; Mayer and Gavin, 2005). Besides, organizational factors, for example, being a member of the board of directors, can also influence member commitment to the cooperative (Cechin, et al., 2013). In addition, commitment is affected by the degree of membership heterogeneity and the way how the property rights are defined and allocated within the cooperative (Bijman and Verhees, 2011).

Most of the research referred above is based on the three-component model of commitment proposed by Allen and Meyer (1990). According to Allen and Meyer, different components of commitment correlate with different factors. For instance, affective commitment is correlated with the comfortable feelings with the individual's role and competence in the organization, while continuance commitment is related to the individual's perception with regard to the alternative availability and the particular investment made within the 
organization. However, there is very little empirical research that systematically investigates the factors contributing to the different mind-sets of member commitment from the perspectives of both member characteristics and organization characteristics. By examining the antecedents of member commitment from both perspectives of members and cooperatives, we can gain a better insight into the means of maintaining and improving member commitment under the cooperative settings.

\subsection{Background}

China is deeply influenced by Confucian philosophy. The Chinese society is emphasized by a strong respect for hierarchy to preserve harmonious interpersonal relationships ( $\mathrm{Li}$ and Sun, 2015). Chinese society (mainland China) is also characterized by high power-distance and collectivism. Saving face culture is a byproduct of Confucianism and collectivism and influences Chinese's ways of thinking and behavior. Hofstede (2001, p.211) suggests that "in the collectivistic Chinese society, the individual is not inner-directed at all but controlled by a need for not losing face." Saving face culture emphasizes that not only does an individual's own face matter, but others' also do (Oetzel and Ting-Toomey, 2003). Mutual-face is one of the most important concerns for Chinese's social life, which can be social pressure sometimes for individuals' social life.

Entrepreneurial farmers play an important role not only in developing modern agriculture but also farmers' cooperatives in China. Liang and Hendrikse (2013) find that entrepreneurial farmers, who usually have more capital and better capabilities with social or professional networks than common farmers, play a critical role in the initiation of cooperatives. These initiators are usually the leaders (or chairpersons) of the cooperatives. Leaders play a critical role in the organisation. Trust in the leaders influence the employees' attitudes and commitment to the organisation and participation behaviours (Barling, et al., 2010, Paunova, 2015).

Besides, members' trust with cooperatives influences the performance and the success of cooperatives. Specifically, trust is supposed to be able to improve cooperation between individuals by enhancing communication and decreasing transaction costs (Tsai and Ghoshal, 1998). Trust can also reduce free-riding problems and facilitate collective action (Ostrom, 2000), thus can improve members' participation in the governance and commitment to the cooperative (Ole Borgen, 2001). 
Although much research has been done on the antecedents of member commitment, there has been little systematic research into the member commitment to agricultural cooperatives, especially the way how these antecedents affect member commitment. Given the important role that leaders play in the cooperatives and the characteristics of Chinese culture, we focus on two factors -- trust in the cooperative leadership and social pressure. We examine the mechanism how trust and social pressure affect members' commitment in Chinese cooperatives. Better understanding of the means through which trust and social pressure can enhance commitment is needed to clarify the relationships and thus allow to explore more effective means of improving member commitment.

The objective of this study is twofold. First, we want to identify the antecedents of member commitment, especially the effect of trust and social pressure on member commitment. Second, we seek to examine the mechanism how trust and social pressure produce effect on member commitment.

\subsection{Theoretical Framework}

Commitment has been discussed under different settings. The four most important settings include commitment in marketing relationship between buyers and sellers, organizational commitment between employees and employers, commitment to associations or clubs between members and associations and member commitment to cooperatives between members and their cooperatives (Sloot, 2016). Specifically, organizational commitment has received more attention than the other three kinds of commitment.

We build our theoretical framework on Meyer and Allen's (1991) three-component model of organizational commitment. Organizational commitment theories can be applied to member commitment to cooperatives to some extent. Both organizational commitment and cooperative commitment is about the connections between individuals and the organizations they belong to. Cooperatives are business organizations. Farmers participate in cooperatives to realize their business objects, for example, to improve their market status by joint forces. Besides, organizational commitment theories try to explain the employees' motivations and reasons for being committed to organizations, which is in line with our research objectives of cooperative commitment in this aspect.

Allen and Meyer (1990) conceptualize and measure the commitment in three different components: affective commitment, continuance commitment and normative commitment. 
Affective commitment refers to an individual's identification with and involvement in the organization. Individuals with a strong affective commitment have positive emotion attachment to the organization. They stay within the organization because they want to do so. Normative commitment is obligation-based and is the result from personal internalization of normative pressures (Wiener, 1982). Individuals with a high level of normative commitment believe that staying within an organization is a "right" and moral thing to do. They feel obliged to stay (Meyer and Allen, 1991). Continuance commitment reflects that individuals are aware of the costs associated with leaving the organization. Members with high level of continuance commitment stay within the organization because they do not want to bear the cost of leaving.

\subsubsection{The antecedents of commitment}

Meyer and Allen (1991) think that given the conceptual differences of the three components of commitment, the antecedents of the psychological states reflecting the three components of commitment are different. Individuals who feel competent to meet job challenges and clear and comfortable with their role in the organization tend to have affective commitment to the organization. Alternatives and side bets are important antecedents of continuance commitment (Stanley et al., 2013). Less research about normative commitment has been done than about the other two components of commitment and most of the studies are based on theoretical rather than empirical analysis. The antecedents for normative commitment thus have not been indicated specifically by empirical research.

Meyer, et al. (2002) have categorized the antecedents of commitment are into four groups: demographic characteristics, individual differences, work experiences and alternatives/investments. However, other antecedents of commitment may be also important, such as social environment factors and organizational factors.

Organizational culture is a pattern of beliefs and expectations shared by the organization's members. These beliefs and expectations produce norms that powerfully shape the behavior of individuals and groups (Schwartz and Davis, 1981). Given the deep influence of Confucius culture on Chinese's beliefs and behaviors, cultural factors, e.g. social pressure, should not be neglected. Another focus of antecedent of member commitment is trust (in the leadership) given the fact that chairpersons play an important role in the development of Chinese cooperatives. 
As regards to the organizational factors, Morris and Steers' (1980) empirical research about the relationship of several aspects of organization structure with organizational commitment suggests that organizational structure should be included as one important variable in estimating factors influencing organizational commitment. According to their research, variables of organization structures represent structural properties of the organization including decentralization, work group size and other aspects. Organizational structure does not only refer to the organization's physical composition (e.g. group size), but also the organization's internal governance, which refers to structures and processes of decisionmaking within organizations (Jones, 2013; Bijman et al., 2014).

Trust

Though a concise and widely accepted definition of trust remains elusive, trust can fundamentally be conceptualized as a psychological state. Trust is characterized as a state of perceived vulnerability or risk, which derives from an individual's uncertainty about the dependents' motive, intentions and prospective actions (Kramer, 1999). According to Robinson (1996), trust is a person's beliefs about the other's future actions to be beneficial, at least not harmful, to one's interest. In the cooperative settings, members' vulnerability towards the cooperative can be understood in view of their dependence on the latter in terms of revenue and information (Borgen, 2001; Barraud-Didier et al., 2012). It is this uncertainty about the behavior of one of the parties of the exchange which makes trust a determinant of the attitudes and behaviors of the other party (Kollock, 1994). Trust in the cooperative affects both members' participation in the cooperative governance and commitment to the cooperative.

According to Salancik and Pfeffer (1978), individual attitudes and behaviors can be predicted by studying the informational and social environment where attitude forms and behavior occurs and adapts. The existing research has indicated the important influence of social and cultural environment on human behaviors (Carter, 2013).

Latane (1981) defines social impact as any influence on individual feelings, thoughts, or behavior that is exerted by the real, implied, or imagined presence or actions of others, which indicates the influence of social environment in shaping the participants. We define social pressure here as personal concerns with the negative impact of factors relating to the social environment and local culture on the person's feelings, thoughts and behaviors. Social pressure is a narrow and personal interpretation of social norms in this sense. 
Due to China's Confucian legacy, the interpersonal relationship (or guanxi) is the most important characteristic of China society. Chinese tend to "view themselves interdependent with the surrounding social context" (Tsui and Farh, 1997, p.60) and thus value not only selfface, but also others' face. On the one hand, guanxi can be one's important social capital. On the other hand, guanxi has become one of the social norms that Chinese follow in their social life. Concerns for guanxi and mutual-face with people in the same community influence Chinese's attitude to both personal relationship and the relationship with organizations. These concerns can be social pressure and affect individuals' choices sometimes.

\section{Member Participation}

Morris and Steers (1980) find empirical evidence for a significant positive influence of organization structure on organization commitment and individuals' perceived participation in the decision making. Though views diverge on how to define participation in a group (Agarwal, 2001), here we specify member participation as the member's participation in the decision-making process within the cooperative.

The importance of membership participation for the cooperative is determined by the characteristics of cooperatives -- a cooperative is owned, controlled and patronized by its members. First, members' participation in the decision making can help to realize members' control over the cooperative. In addition to the capital provided by the cooperative members, cooperatives are also financed by a fairly amount of unallocated equity capital (Dunn, 1988). Second, members' participation relates to the core element of the cooperative - the principle of democracy. Participating in the decision-making process allow members to voice their opinions. When their voice is not valued or heard, they may choose to terminate membership.

\subsubsection{Hypotheses about the relationship among trust, member participation and member} commitment

Trust in cooperatives improves members' participation in the governance (Borgen, 2001). Using data of Swedish farmers, Nilsson et al. (2009) have found confirmation for the claim that trust in the cooperative management is positively correlated with members' involvement in the cooperative decision-making processes. We thus hypothesize that:

H1: Trust in cooperatives improves member participate in the decision-making process.

Trust induces commitment (Yilmaz and Hunt, 2001). Jiang and Probst (2016) use data from 1071 staff and administrative professionals at a large university and show that trust in 
management is positively related to affective commitment. When the members trust their cooperatives, particularly regarding cooperatives' ability, goodwill and honesty, member commitment tends to increase and identification with the cooperative becomes stronger (Jiménez et al., 2010). The possible cause is that people trusting each other can synchronize and work together constructively and thus can improve the decision quality and make problems solved effectively. This leads to increased commitment (Sholihin et al., 2011). Similarly, employees who trust the management are likely to be more committed to the organization (Laschinger et al., 2000). Therefore, we hypothesize that:

$\mathrm{H} 2$ : Trust in cooperatives is positively associated with member commitment.

Member commitment is related to member participation in the cooperative. Osterberg and Nilsson (2009) maintain that member participation in the cooperative decision-making process positively relates to members' commitment to the cooperative. The more the members perceive that they participate in the governance of the cooperative governance, the more committed to the cooperative they are. Active member participation and member commitment makes cooperatives survive in the long run (Bhuyan, 2007). We thus hypothesize that:

H3: Member participation is positively associated with member commitment.

If $\mathrm{H} 1, \mathrm{H} 2$ and $\mathrm{H} 3$ are all supported in the subsequent empirical analyses, it will be reasonable to propose that member participation plays a mediating role between trust and member commitment. That is to say, not only does trust impact members' commitment to cooperatives directly, but also indirectly via members' participation in the decision-making process.

\section{Social pressure, member participation and member commitment}

Literatures on the relationship between social influence and participation can be found in research on community governance and community cooperation. Kandori (1992) points out that members in the community can observe each other's behaviors and reactions. Social norms, particularly peer monitoring of complying to the norms and sanction rules within community, can force members to participate in community activities. We hypothesize that:

H4: Social pressure leads to member participation.

Given the distinctive characteristic of different components of commitment, we cannot make a uniform hypothesis about the relationship between local social pressure and member 
commitment. When we consider the impact of social pressure on behavioral intentions, it is reasonable that the greater the pressure on members to conform to the community's norms and objectives, the more burdensome members will feel. The burdensome feelings can be negative to affective commitment. Therefore, we hypothesis that:

H5: Social pressure is negatively related to affective commitment.

Community applies both awards and punishments to members depending on members' behaviors which are either in accordance with or deviating from the social norms (Bowles and Gintis, 2002). Individuals' socialization is reached by living by the social norms of one's community and punishing when not complying. Social pressure and other social influences generate internalization and identification on community members (Bagozzi and Dholakia, 2002). Social pressure thus has a positive influence on normative commitment.

Hence, we hypothesize that:

H6: Social pressure is positively related to normative commitment.

Social pressure comes from individuals' concerns about the negative effects exerted by guanxi. Destroying guanxi with others can affect individuals' economic or other benefits and leaving cooperatives thus can make Chinese cooperative members to have a sense of loss. Therefore, we hypothesize that:

H7: Social pressure is positively related to continuance commitment.

The conceptual framework is presented in Figure 5.1.

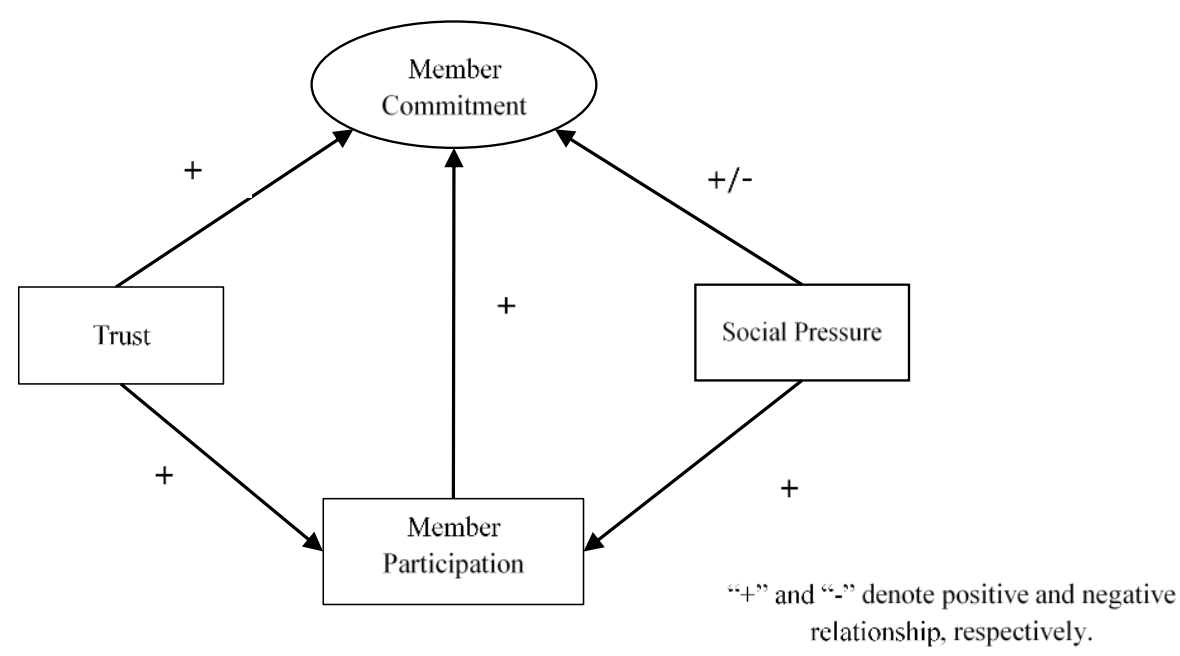

Figure 5.1 Conceptual framework 


\subsection{Methodology}

\subsubsection{Research setting, subjects and design}

We conducted a survey among farm households in the Shaanxi Province in the Loess Plateau area and the Shandong Province in the Bohai Gulf area. The survey was carried out between January and March 2015. A multistage sampling procedure was used for the selection of observation units. In the first stage, we used the probability proportional to size (PPS) method to select 7 counties (out of the 10 most important apple production counties) in Shaanxi and 8 counties (out of the 10 most important apple production counties) in Shandong according to the size of apple production in 2014. In the second stage, we asked the Agricultural Bureau in each county for the list of apple cooperatives in the county; 5 cooperatives were randomly selected from those lists. Therefore, in total we first selected 75 cooperatives. However, 12 out of the 75 selected cooperatives could not be reached. Therefore, we dropped these 12 cooperatives from our sample resulting in a final sample of 63 cooperatives that were interviewed (30 in Shaanxi and 33 in Shandong). We did face-to-face interviews with the chairperson or other officials involved in cooperative management. Data about the cooperative (e.g. number of members, initiation) were collected. Members were also interviewed individually and information about the demographical and farm characteristics was collected, such as age, education, farm size and asset investments, and attitude towards cooperatives and towards colleagues. 429 member households were interviewed. Due to the missing information, 38 out of the 429 were removed from the sample and data about 391 members were used in the analysis.

\subsubsection{Measures}

\section{Member Commitment}

Despite the theoretical and practical importance of commitment to an organization, its measurement is difficult. As mentioned in the previous part, member commitment is generally measured in two ways, either by behaviors or by attitudes. For instance, commitment is usually measured using proxy variables such as financial contribution to the cooperative or selling outputs to the cooperative. Even though these proxies measure certain forms of commitment, sometimes contributions are mandatory, and members sell to the cooperative not because they are committed, rather they have no option. Hence, measuring commitment through behavior is less appropriate. 
Following the more recent organizational commitment literature (Solinger, et al., 2008; Cechin, et al., 2013), member commitment is defined as members' attitudinal commitment to the organization. Our measurement is based on the well-established three-component model by Allen and Meyer (1990) and Meyer et al. (2002) (pp. 20-52), v.i.z. affective, normative, and continuance commitment. We adapted the items to the farmer cooperative context.

The affective component is believed to be an emotional attachment to an organization, so that the strongly committed member identifies with the organization. The normative component refers to members' sense of obligation to remain with the organization. The continuance component corresponds to a lack of choices and when leaving it would entail the loss of acquired advantages for members.

Responses to the statements about members' attitudes towards cooperatives were made on a 5 -point Likert scale $(1=$ strongly disagree and 5= strongly agree). The resulting instrument yielded 12 separate commitment constructs measuring the three bases of affective, continuance, and normative commitment. The following three items are examples of the modification: (1) "I will feel proud if the cooperative is developing successfully." (Affective Commitment); (2) "It would be economically costly for me to leave my cooperative." (Continuance Commitment); and (3) "Jumping from this cooperative to other organization seems unethical to me." (Normative Commitment). Column 4 in Table 2 lists the reliability coefficients for the 12 commitment constructs. All coefficient alphas are above 0.70 except Normative Commitment that is at 0.56 . These alphas are acceptable given the early stages of research with these constructs (Nunnally, 1978). Additionally, the results of exploratory factor analysis indicate that the items for Affective Commitment, Continuance Commitment and Normative Commitment load nicely onto a single latent factor, respectively. The construct validity will be discussed in the measurement model estimations.

Trust

Here we conceptualize trust as trust in the leadership, which is defined as members' confidence in the leader person's motives with respect to matters relevant to the members' benefits and leaders' abilities of dealing with cooperative business.

The chairperson plays an important role both in the initiation and the operation of a Chinese farmer cooperative. Chairpersons' capability in information collection and marketing affects the viability and development of the cooperative (Liang and Hendrikse, 2013). Given the critical role of the cooperative chairperson, we thus measure members' trust with the 
cooperative by measuring their trust in the chairperson. For example, trust in the chairperson's character (“I trust in the co-op chairperson's character.), trust in the chairperson's management capability ("I trust in the chairperson's management ability.") and members' self-evaluation with the trustworthiness of the cooperative in general ("The co-op has a good reputationof being reliable."). The scale reliability test shows that all coefficient alphas are above 0.70 and the results of exploratory factor analysis indicate that the items for trust load nicely onto a single latent factor.

\section{Social pressure}

Interpersonal relationship (or guanxi) is one of the most important components of Chinese social values. Guanxi is double-edged and it does not only benefit parties involved, but can also become social pressure for one party because of the high expectation from the others (Qi, 2013). We have five statements to depict the social pressure within Chinese society context. (1) The reason why I stay in the cooperative is that social pressure forces me to do so. (2) My relationship with other members will be disturbed if I quit the cooperative. (3) Since most of the villagers have joined the cooperative, I will be isolated if I exit. (4) I will feel embarrassed if I go to the chairperson and tell him/her that I want to quit. (5) I worry that I will make the chairperson lose face if I quit. The coefficient alphas of these five items are around 0.80 . The exploratory factor analysis indicates that the items for social pressure nicely load onto a single latent factor.

\section{Member participation}

The levels of participation range from nominal membership to dynamic interactive process in which the disadvantaged have voice and influence in the decision-making (White, 1996). Here the participation refers to participation in the decision-making process. We generally follow the participation typology (see Table 5.1) proposed by Agarwal (2001), where the participation levels are defined by the extent of people's activeness. 
Table 5.1 Typology of member participation in the decision-making

\begin{tabular}{ll}
\hline Form/level of participation & Characteristic features \\
\hline Nominal participation & Merely membership in the group. \\
Passive participation & $\begin{array}{l}\text { Attending meetings and listening in on decision making, without speaking } \\
\text { up. }\end{array}$ \\
Consultative participation & $\begin{array}{l}\text { Being asked an opinion in specific matters without guarantee of } \\
\text { influencing the decisions. }\end{array}$ \\
Active participation & Fully expressing opinions, whether solicited or not. \\
\hline
\end{tabular}

Note: This is a modified version of the typology presented in Agarwal (2001).

\section{Other variables about organizational structure}

Besides members' participation in the decision making process, other aspects of organization structure are also taken into account, for example, organization's internal governance, which refers to structures and processes of decision-making within organizations (Bijman, et al., 2014). Therefore, we include variables of whether the member has shares in the cooperative, whether the cooperative distributes dividends to members, and whether the board of directors are democratically elected. Other variables about organization's physical composition (e.g. group size) and whether there are constraints for members to exit the cooperative are also included.

\section{Control variables and other variables}

Control variables include members' demographical and household characteristics, for example, gender, age, education, farm size and household size. According to Baumeister and Leary (1995), members of strongly cohesive groups are more inclined to participate readily and to stay with the group. Thus self-evaluated group cohesiveness is included for both participation and member commitment models. We measure group cohesion by two indicators - members' concern about the cooperative's future development and the selfevaluation of the cooperative's problem solving abilities. Additionally, we also include variables of members' satisfaction with the service provided by the cooperative. The member satisfaction is indicated by the farmer on a 5-point Likert scale ranging from very satisfied to very unsatisfied. 
Table 5.2 presents the descriptive statistics of the measurements of different latent constructs and other variables used in the analyses. 
Table 5.2 Descriptive statistics

\begin{tabular}{|c|c|c|c|c|}
\hline $\begin{array}{l}\text { Variable } \\
\text { name }\end{array}$ & Mean (S.D.) & $\begin{array}{l}\text { Reliability } \\
\text { coefficient } \\
\alpha \\
\end{array}$ & $\begin{array}{l}\text { Scale } \\
\text { reliability } \\
\text { coefficient }\end{array}$ & Description \\
\hline age & $51.793(8.077)$ & na & na & Age of the household head \\
\hline education & $8.440(2.918)$ & na & na & Education years of the household head \\
\hline $\begin{array}{l}\text { village } \\
\text { cadre }\end{array}$ & $0.258(0.438)$ & na & na & $\begin{array}{l}\text { Whether the household head or other family member has the } \\
\text { work experience of being the village cadre. }(0=\text { no })\end{array}$ \\
\hline housesize & $3.775(1.372)$ & na & na & Household size \\
\hline non-farm & $0.102(0.320)$ & na & na & $\begin{array}{l}\text { Whether the household participates in the non-farm work }(0=\text { no; } \\
1=\text { yes })\end{array}$ \\
\hline land & $8.181(7.386)$ & na & na & size of land bearing fruits (unit: $\mathrm{mu}$ ) \\
\hline share & $0.148(0.356)$ & na & na & whether have shares in the co-op $(0=$ no; $1=$ yes $)$ \\
\hline dividends & $0.138(0.345)$ & na & na & whether the coop have dividends $(0=$ no; $1=$ yes $)$ \\
\hline BoD & $0.404(0.491)$ & na & na & $\begin{array}{l}\text { Whether the Board of Directors are democratically elected }(0=\text { no; } \\
1=\text { yes) }\end{array}$ \\
\hline exit & $0.100(0.300)$ & na & na & Whether there is constraint to exit the co-op $(0=$ no; $1=$ yes $)$ \\
\hline satisfaction & $4.043(0.917)$ & na & na & $\begin{array}{l}\text { degree of satisfaction with the coop in general (in Likert scale: } 1= \\
\text { very unsatisfied; } 5=\text { very satisfied) }\end{array}$ \\
\hline land_coop & $3995.9(5581.8)$ & na & na & The total land size of the members and the co-op (unit: $\mathrm{mu}$ ) \\
\hline region & $0.483(0.500)$ & na & na & Regional dummy (Shandong=0; Shaanxi $=1$ ) \\
\hline cohesion 1 & $2.637(1.334)$ & na & na & Members care little about the co-op's future development. \\
\hline cohesion2 & $4.202(1.001)$ & na & na & The members can generally solve the problems together. \\
\hline trust1 & $4.455(0.884)$ & 0.722 & & I trust in the co-op chairman's character. \\
\hline trust2 & $4.320(1.046)$ & 0.722 & 0.812 & I trust in the chairman's management ability. \\
\hline trust3 & $4.189(1.043)$ & 0.779 & & The co-op has great reputations of being reliable. \\
\hline Pressure 1 & $2.059(1.271)$ & 0.742 & & $\begin{array}{l}\text { The reason why I stay in the co-op is that social pressure forced } \\
\text { me to do so. }\end{array}$ \\
\hline Pressure2 & $2.315(1.398)$ & 0.755 & 0812 & $\begin{array}{l}\text { My relationship with the members will be disturbed if I quit the } \\
\text { co-op membership. }\end{array}$ \\
\hline Pressure 3 & $2.223(1.347)$ & 0.738 & 0.812 & $\begin{array}{l}\text { Since the majority of the villagers have joined in the co-op, I will } \\
\text { be isolated if I exit. }\end{array}$ \\
\hline Pressure4 & $2.049(1.230)$ & 0.814 & & $\begin{array}{l}\text { I worry that I will make the chairman to feel lose face if I want to } \\
\text { quit. }\end{array}$ \\
\hline $\mathrm{AC} 1$ & $4.005(1.114)$ & 0.741 & & I will treat the co-op business as my own. \\
\hline AC3 & $4.090(1.125)$ & 0.669 & 0.774 & $\begin{array}{l}\text { I don't think that I could become as emotionally } \\
\text { attached to another co-op as this one. }\end{array}$ \\
\hline $\mathrm{AC} 4$ & $4.317(0.884)$ & 0.678 & & I feel that the members are like my families. \\
\hline $\mathrm{CC} 1$ & $3.437(1.448)$ & 0.800 & & It would be very economically costly for me to leave my co-op. \\
\hline $\mathrm{CC} 2$ & $3.816(1.280)$ & 0.696 & & I can have stable marketing channels if I stay in the co-op. \\
\hline $\mathrm{CC} 3$ & $3.693(1.325)$ & 0.703 & 0.800 & I can sell my apples with higher prices if I stay in the co-op. \\
\hline $\mathrm{CC} 4$ & $4.279(1.063)$ & 0.790 & & $\begin{array}{l}\text { I can have better access to market information if I stay in the co- } \\
\text { op. }\end{array}$ \\
\hline $\mathrm{NC} 1$ & $3.453(1.447)$ & 0.801 & & $\begin{array}{l}\text { Jumping from this co-op to other organization seems unethical to } \\
\text { me. }\end{array}$ \\
\hline $\mathrm{NC} 2$ & $4.271(0.935)$ & 0.667 & 0.772 & $\begin{array}{l}\text { I believe that loyalty is important and therefore I feel a sense of } \\
\text { moral obligation. }\end{array}$ \\
\hline NC3 & $4.115(1.137)$ & 0.594 & & I was taught to remain loyal when I was young. \\
\hline participation & $2.463(1.092)$ & na & na & $\begin{array}{l}\text { Self-evaluated levels of participating in the decision-making } \\
\text { process: } 1=\text { Membership in the group; } \\
\text { 2=Attending meetings and listening in on decision making, } \\
\text { without speaking up } \\
3=\text { Being asked an opinion in specific matters without guarantee } \\
\text { of influencing the decisions } \\
4=\text { Fully expressing opinions, whether or not solicited }\end{array}$ \\
\hline
\end{tabular}

Note: "na" denotes not applicable. S.D. denotes standard deviations. 


\subsection{Analysis, results and discussions}

To test the hypothesis, structural equation modeling (SEM) methods are used for the analysis with STATA 14.0. SEM simultaneously examines both measurement and structural equations. The measurement equation identifies the relationship between the indicators and the constructs (or latent variables) they represent (Bollen and Long, 1992). The structural equation specifies the relationships among constructs. Though these two equations can be estimated together, they should be interpreted separately (Hulland, 1999). The estimates of measurement equations and structural equations are shown in Table 5.3 and Table 5.5, respectively.

Values of the indices measuring the overall model fit are all below the acceptance criteria. For affective commitment estimations, the values of root mean squared error of approximation (RMSEA) is 0.031, comparative fit index (CFI) 0.969 and standardized root mean squared residual (SRMR) 0.031. For continuance commitment, the values for RMSEA, CFI and SRMR are 0.031, 0.967 and 0.033, respectively. For normative commitment, the values for RMSEA, CFI and SRMR are 0.048, 0.927 and 0.033, respectively. The results show that the SEM models fit the data well.

\subsubsection{Measurement model analysis}

The results reveal that all measures are significant at the $1 \%$ level and about or above the 0.60 loading level. Loading with a minimum of 0.60 indicates that the measures account for at least 60 percent of the variance of the underlying latent variable (Chin, 1998). Furthermore, construct validity requires convergent and discriminant validity (Hair et al., 2010), which can be assessed with average variance extracted (AVE) and composite reliability statistics (CR) (Fornell and Larcker, 1981). The values of AVE for the latent constructs are all above 0.5 and $\mathrm{CR}$ for the constructs are all above 0.7 . These results thus confirm the good validity of the latent constructs. 
Table 5.3 Estimation results from measurement models by using SEM

\begin{tabular}{|c|c|c|c|}
\hline Construct & Indicators & Coefficient & Standard Errors \\
\hline TRUST & trust1 & $0.785^{* * * *}$ & 0.027 \\
\hline $\mathrm{CR}=0.88$ & trust2 & $0.799^{* * * *}$ & 0.026 \\
\hline \multirow[t]{2}{*}{$\mathrm{AVE}=0.59$} & trust3 & $0.722^{* * * *}$ & 0.031 \\
\hline & Pressure1 & $0.788^{* * *}$ & 0.029 \\
\hline SOCIAL PRESSURE & Pressure2 & $0.764^{* * * *}$ & 0.029 \\
\hline \multicolumn{4}{|l|}{$\mathrm{CR}=0.88$} \\
\hline \multirow[t]{2}{*}{$\mathrm{AVE}=0.53$} & Pressure3 & $0.762^{* * *}$ & 0.031 \\
\hline & Pressure4 & $0.573^{* * * *}$ & 0.041 \\
\hline AFFECTIVE COMMITMENT & $\mathrm{AC} 1$ & $0.717^{* * *}$ & 0.031 \\
\hline (AC) & $\mathrm{AC} 2$ & $0.738^{* * *}$ & 0.030 \\
\hline \multicolumn{4}{|l|}{$\mathrm{CR}=0.86$} \\
\hline $\mathrm{AVE}=0.55$ & AC3 & $0.764^{* * * *}$ & 0.029 \\
\hline CONTINUANCE & $\mathrm{CC} 1$ & $0.589^{* * *}$ & 0.037 \\
\hline $\begin{array}{l}\text { COMMITMENT } \\
\text { (CC) }\end{array}$ & $\mathrm{CC} 2$ & $0.842^{* * * *}$ & 0.022 \\
\hline $\mathrm{CR}=0.88$ & $\mathrm{CC} 3$ & $0.836^{* * *}$ & 0.022 \\
\hline $\mathrm{AVE}=0.53$ & $\mathrm{CC} 4$ & $0.610^{* * * *}$ & 0.036 \\
\hline NORMATIVE COMMITMENT & $\mathrm{NC} 1$ & $0.570^{* * * *}$ & 0.040 \\
\hline$(\mathrm{NC})$ & $\mathrm{NC} 2$ & $0.806^{* * * *}$ & 0.031 \\
\hline $\mathrm{CR}=0.86$ & & & \\
\hline $\mathrm{AVE}=0.55$ & $\mathrm{NC} 3$ & $0.826^{* * *}$ & 0.036 \\
\hline
\end{tabular}

Note: ${ }^{* * *}$ denotes the $1 \%$ significance level. CR and AVE are the abbreviations of composite reliability and average variance extracted, respectively. 


\subsubsection{Structural model analysis}

The structural model is applied to test the hypothesized relationships. In this study, we do step-by-step estimations by using SEM to test the effects of trust and social pressure on different components of member commitment and member participation, which also allows us to examine the role of participation in the relationship between trust, social pressure and member commitment. The results are presented in Table 5.4.

First, we include only trust in the SEM to estimate the direct effect of trust on Affective Commitment (AC), Normative Commitment (NC) and Continuance Commitment (CC), respectively. The results are presented in the $3^{\text {rd }}$ line of Panel A in Table 5.4. We learn that trust has a positive direct effect on $\mathrm{AC}, \mathrm{NC}$ and $\mathrm{CC}$, respectively $\left(\mathrm{R}^{2}\right.$ is $0.438,0.332$ and 0.174 , respectively). Similarly, we also include only social pressure in SEM to estimate the direct effect of trust on $\mathrm{AC}, \mathrm{NC}$ and $\mathrm{CC}$, respectively. We conclude from the estimation results of social pressure (shown in the $3^{\text {rd }}$ line of Panel B) that social pressure also has positive direct effect on $\mathrm{AC}, \mathrm{NC}$ and $\mathrm{CC}$. 
Table 5.4 Estimates of direct and mediating effects of trust and social pressure on AC, NC and CC by using SEM

\begin{tabular}{|c|c|c|c|}
\hline \multicolumn{4}{|c|}{ Panel A: Direct effect, only including TRUST } \\
\hline & $\mathrm{AC}$ & $\mathrm{NC}$ & $\mathrm{CC}$ \\
\hline Trust & $0.662^{* * * *}(0.042)$ & $0.418^{* * * *}(0.055)$ & $0.576^{* * *}(0.045)$ \\
\hline $\mathrm{R}^{2}$ & 0.438 & 0.332 & 0.174 \\
\hline
\end{tabular}

Panel B: Direct effect, only including social pressure

\begin{tabular}{llll}
\hline & AC & NC & CC \\
\hline Social pressure & $0.147^{* *}(0.061)$ & $0.330^{* * *}(0.055)$ & $0.120^{* *}(0.059)$ \\
$\mathrm{R}^{2}$ & 0.021 & 0.332 & 0.014 \\
\hline
\end{tabular}

Panel C: Effect of trust on AC/NC/CC, respectively (including both trust and participation as antecedents of AC/NC/CC )

\begin{tabular}{|c|c|c|c|c|c|c|}
\hline & participation & $\mathrm{AC}$ & participation & $\mathrm{NC}$ & participation & $\mathrm{CC}$ \\
\hline Trust & $0.260^{* * *}(0.05)$ & $0.615^{* * * *}(0.04)$ & $0.262^{* * * *}(0.05)$ & $0.399^{* * *}(0.05)$ & $0.259^{* * * *}(0.05)$ & $0.579^{* * * *}(0.04)$ \\
\hline participation & -- & $0.180^{* * * *}(0.04)$ & -- & $0.092^{*}(0.055)$ & -- & $-0.013(0.050)$ \\
\hline Direct effect & \multicolumn{2}{|c|}{$1.602^{* * *}(0.368)$} & \multicolumn{2}{|c|}{$1.130^{* * * *}(0.298)$} & \multicolumn{2}{|c|}{$1.723^{* * *}(0.410)$} \\
\hline Indirect effect & \multicolumn{2}{|c|}{$0.122^{* * * *}(0.034)$} & \multicolumn{2}{|c|}{$0.068^{*}(0.042)$} & \multicolumn{2}{|c|}{$-0.010(0.039)$} \\
\hline Total effect & \multicolumn{2}{|c|}{$1.724^{* * *}(0.372)$} & \multicolumn{2}{|c|}{$1.198^{* * *}(0.298)$} & \multicolumn{2}{|c|}{$1.713^{* * *}(0.412)$} \\
\hline
\end{tabular}


Panel D: Effect of social pressure on AC/NC/CC (including social pressure and participation as antecedents of $\mathrm{AC} / \mathrm{NC} / \mathrm{CC}$, respectively)

\begin{tabular}{|c|c|c|c|c|c|c|}
\hline & participation & $\mathrm{AC}$ & participation & $\mathrm{NC}$ & participation & $\mathrm{CC}$ \\
\hline $\begin{array}{l}\text { Social } \\
\text { Pressure }\end{array}$ & $0.015(0.033)$ & $0.14^{* *}(0.059)$ & $0.015(0.05)$ & $0.329^{* * * *}(0.05)$ & $0.015(0.037)$ & $0.118^{* *}(0.059)$ \\
\hline participation & -- & $0.336^{* * *}(0.05)$ & -- & $0.169^{* * *}(0.05)$ & -- & $0.133^{* *}(0.053)$ \\
\hline Direct effect & \multicolumn{2}{|c|}{$6.387(14.635)$} & \multicolumn{2}{|c|}{$16.630(55.159)$} & \multicolumn{2}{|c|}{$6.159(16.046)$} \\
\hline Indirect effect & \multicolumn{2}{|c|}{$0.228^{* * *}(0.039)$} & \multicolumn{2}{|c|}{$0.129^{* * * *}(0.043)$} & \multicolumn{2}{|c|}{$0.101^{* *}(0.042)$} \\
\hline Total effect & \multicolumn{2}{|c|}{$6.615(14.636)$} & \multicolumn{2}{|c|}{$16.759(55.161)$} & \multicolumn{2}{|c|}{$6.260(16.047)$} \\
\hline
\end{tabular}

Note: ${ }^{*},{ }^{* *},{ }^{* * *}$ denote significant levels of $10 \%, 5 \%$ and $1 \%$, respectively. Standard errors are inside the brackets.

Next, to test the role of member participation between trust and social pressure and different components of commitment, we include member participation and trust (or social pressure) as antecedents of AC, NC and CC, respectively based on the first step. The results are shown in Panel C and Panel D of Table 5.4, respectively.

Panel C and Panel D show that trust has positive direct effect on both three components of commitment and member participation. In contrast, social pressure has insignificant direct effect on member commitment. Besides, both trust and social pressure exert significant indirect effects on both affective and normative commitment through member participation. Trust has no significant indirect effect on continuance commitment, but social pressure does. Thirdly, we conduct the full model estimations by including both trust and social pressure and other control variables. The results are shown in Table 5.5. The further decomposed effects of trust and social pressure on different components of commitment are shown in Table 5.6. From the estimated coefficients of trust for both participation equations and commitment equations and the computation of direct/indirect/total effects of trust on member commitment, we learn that trust has a positive direct effect on both member participation and the three components of member commitment.

Trust has positive indirect effects only on affective commitment, but no significant indirect effect on either normative commitment or continuance commitment. However, the total effect 
of trust on three components of member commitment is significant and positive (shown in Table 5.6), which confirms hypotheses $\mathrm{H} 1$ and $\mathrm{H} 2$. 
Table 5.5 Estimation results of structural models: standardized estimates of affective commitment (AC), normative commitment (NC)continuance commitment (CC) and participation

\begin{tabular}{|c|c|c|c|c|c|c|c|c|c|c|c|c|}
\hline \multirow{2}{*}{$\begin{array}{l}\text { Explanator } \\
\text { y variables }\end{array}$} & \multicolumn{2}{|c|}{ Participation } & \multicolumn{2}{|c|}{$\mathrm{AC}$} & \multicolumn{2}{|c|}{ Participation } & \multicolumn{2}{|c|}{$\mathrm{NC}$} & \multicolumn{2}{|c|}{ Participation } & \multicolumn{2}{|c|}{$\mathrm{CC}$} \\
\hline & coef. & S. E. & coef. & S. E. & coef. & S. E. & coef. & S. E. & coef. & S. E. & coef. & S. E. \\
\hline age & 0.068 & 0.053 & $0.103^{* *}$ & 0.048 & 0.068 & 0.053 & $0.093^{*}$ & 0.054 & 0.068 & 0.053 & -0.081 & 0.050 \\
\hline education & $0.099^{* *}$ & 0.050 & 0.008 & 0.045 & $0.100^{* *}$ & 0.050 & -0.046 & 0.051 & 0.099 & 0.050 & 0.031 & 0.047 \\
\hline $\begin{array}{l}\text { village } \\
\text { cadre }\end{array}$ & 0.055 & 0.052 & -0.034 & 0.047 & 0.055 & 0.052 & 0.033 & 0.053 & 0.055 & 0.052 & 0.016 & 0.049 \\
\hline non-farm & -0.039 & 0.050 & -0.022 & 0.045 & -0.039 & 0.050 & 0.027 & 0.051 & -0.039 & 0.050 & -0.074 & 0.047 \\
\hline land size & 0.001 & 0.049 & -0.055 & 0.044 & 0.001 & 0.049 & -0.064 & 0.050 & 0.001 & 0.049 & -0.007 & 0.046 \\
\hline share & 0.007 & 0.070 & -0.021 & 0.062 & 0.007 & 0.070 & 0.006 & 0.070 & 0.008 & 0.070 & -0.005 & 0.065 \\
\hline dividends & 0.059 & 0.070 & 0.040 & 0.063 & 0.059 & 0.070 & 0.053 & 0.071 & 0.058 & 0.070 & 0.014 & 0.066 \\
\hline $\mathrm{BoD}$ & $0.089^{*}$ & 0.049 & -0.002 & 0.045 & $0.089^{*}$ & 0.049 & 0.013 & 0.050 & 0.089 & 0.049 & $0.089^{*}$ & 0.046 \\
\hline exit & $-0.085^{*}$ & 0.048 & 0.009 & 0.044 & $-0.086^{*}$ & 0.048 & -0.013 & 0.049 & -0.085 & 0.048 & $-0.083^{*}$ & 0.046 \\
\hline satisfication & -0.017 & 0.056 & $0.234^{* * * *}$ & 0.051 & -0.017 & 0.056 & $0.259^{* * * *}$ & 0.056 & -0.018 & 0.056 & $0.199^{* * *}$ & 0.052 \\
\hline land_coop & -0.109 & 0.048 & 0.034 & 0.043 & -0.109 & 0.048 & 0.047 & 0.049 & -0.109 & 0.048 & $-0.075^{*}$ & 0.045 \\
\hline region & 0.243 & 0.051 & $0.128^{\text {**** }}$ & 0.048 & 0.243 & 0.051 & $0.154^{* * * *}$ & 0.054 & 0.243 & 0.051 & 0.049 & 0.051 \\
\hline cohesion 1 & -0.050 & 0.052 & $0.129^{* * * *}$ & 0.047 & -0.049 & 0.052 & 0.003 & 0.053 & -0.050 & 0.052 & $-0.133^{* * * *}$ & 0.048 \\
\hline cohesion 2 & -0.031 & 0.054 & $0.219^{* * * *}$ & 0.048 & -0.031 & 0.055 & $0.106^{* *}$ & 0.055 & -0.031 & 0.054 & $0.120^{* *}$ & 0.051 \\
\hline $\begin{array}{l}\text { Participatio } \\
\mathrm{n}\end{array}$ & -- & -- & $0.152^{\text {**** }}$ & 0.046 & -- & -- & 0.057 & 0.053 & -- & -- & -0.051 & 0.048 \\
\hline Trust & $0.260^{* * * *}$ & 0.067 & $0.371^{\text {**** }}$ & 0.062 & $0.260^{* * * *}$ & 0.067 & $0.222^{* * *}$ & 0.071 & 0.261 & 0.067 & $0.396^{* * *}$ & 0.065 \\
\hline Pressure & -0.025 & 0.055 & $0.098^{* * *}$ & 0.049 & -0.026 & 0.055 & $0.256^{* * *}$ & 0.055 & -0.025 & 0.055 & $0.120^{* * *}$ & 0.051 \\
\hline constant & 2.237 & 0.693 & -- & -- & 2.233 & 0.693 & -- & -- & 2.238 & 0.693 & -- & -- \\
\hline
\end{tabular}

Note: ${ }^{*},{ }^{* *},{ }^{* *}$ denote significant levels of $10 \%, 5 \%$ and $1 \%$, respectively. S.E. stands for standard errors. 
Table 5.6 Mediating role of participation between trust, social pressure and different components of commitment

\begin{tabular}{lcccccc}
\hline & \multicolumn{2}{c}{ Affective Commitment } & Normative Commitment & Continuance Commitment \\
\hline & Trust & $\begin{array}{c}\text { Social } \\
\text { Pressure }\end{array}$ & Trust & Social Pressure & Trust & $\begin{array}{c}\text { Social } \\
\text { Pressure }\end{array}$ \\
\hline Direct effect & $1.041^{* * *}(0.322)$ & $0.078^{* *}(0.040)$ & $0.642^{* *}(0.268)$ & $0.211^{* * *}(0.051)$ & $1.188^{* * * *}(0.374)$ & $0.103^{* *}(0.045)$ \\
Indirect & & & & & & \\
effect & $0.112^{* * *}(0.034)$ & $-0.003(0.007)$ & $0.043(0.040)$ & $-0.001(0.003)$ & $-0.040(0.038)$ & $0.001(0.003)$ \\
Total effect & $1.153^{* * *}(0.323)$ & $0.075^{*}(0.040)$ & $0.685^{* * *}(0.265)$ & $0.210^{* * *}(0.051)$ & $1.148^{* * *}(0.374)$ & $0.104^{* *}(0.045)$ \\
\hline
\end{tabular}

Note: ${ }^{*},{ }^{* *},{ }^{* * *}$ denote significant levels of $10 \%, 5 \%$ and $1 \%$, respectively. Standard errors are inside the brackets.

We learn from Table 5.5 that member participation is only positively associated with affective commitment, but not with the other two components of member commitment. However, the estimates of participation change as we add more explanatory variables into the model, which can be seen from Panel C and Panel D in Table 5.4 to Table 5.5. The results suggest that member participation is closely associated with members' affection with the cooperative, but not related with continuance benefits or social norms and obligations. This reflects the voluntary participation principle of cooperatives. Members participate in the cooperative decision-making activities because they "want to", not because they feel obligated to. The reason for the insignificant effect of social pressure on member participation is that member participation is voluntary and self-motivated. This conclusion is not contradicted with H4. Similar result can be found in the research by Bagozzi and Dholakia (2002).

We also learn that social pressure is positively and directly associated with three components of member commitment from Table 5.5. The results support hypotheses H6 or H7, but are contrary to H5. The contradiction can be explained by the deep influence of the Confusion culture. Concerns for guanxi and mutual-face internalize the burdensome feelings and further transform the negative feelings into a sense of obligation or even affections.

To further investigate the pathway how trust and social pressure produce effect on the dependent variables, we carry out mediation tests of trust and social pressure, respectively. Baron and Kenny (1986) and Avolio et al. (2004) argue that partial mediation exists when the relationship between the independent and the dependent variables remain significant if we control for the effects of mediating variables. The mediation analysis show that member 
participation partially mediates only the relationship between trust and affective commitment. That is to say, trust does not only influence affective commitment in a direct way, but also in an indirect way via the partial mediator of member participation. Social pressure only has significant direct effect on the three components of commitment.

With regards to the effects of other organizational factors, we learn from the results presented in Table 5.5 that if the board of directors are elected democratically and there are no constraints for members to quit cooperative membership, members tend to participate in the cooperative decision making more actively. The cooperative size is negatively associated with continuance commitment. Members' degree of satisfaction with the service provided by the cooperative and group cohesiveness have positive impact on three components of member commitment. In addition, more educated members tend to participate more in the decision making process. Older people have stronger affective and normative commitment to the cooperatives.

\subsection{Conclusions and discussion}

Member commitment is important to cooperatives' viability and success, but its determinants are partly understood. We systematically investigate the factors contributing to the different forms of member commitment from the perspectives of both members' and their organizations' characteristics. Given the important role of chairpersons played in Chinese cooperatives, we specifically examine the relationship among trust in the cooperative leaders, social pressure and members' participation in the decision-making process using a sample of 391 farmer cooperative members in China.

Our study finds that both trust and social pressure are positively associated with the three components of member commitment - affective commitment, continuance commitment and normative commitment. Member participation plays a partially mediating role between trust and affective member commitment. Generally, these findings offer empirical evidence on the importance of trust in the cooperative leadership and of social pressure in maintaining cooperative membership and member commitment. Besides, other organizational factors such as democratic election of the Board of Directors and constraints in quitting membership also significantly affect members' participation in the decision-making process, but not member commitment. 
The Chinese government has been promoting farmers to participate in farmer cooperatives since 2006. Liang and Hendrikse (2013) found that the genesis of cooperatives in China is not the result of bottom-up collective action by small farmers, but is due to the political pressure and the converging interests of specific agricultural entrepreneurs. Deng et al. (2010) claimed that the government is of primary importance in the cooperative establishment. However, successful farmer cooperatives must be voluntarily initiated (Cook, 1995). Therefore, can Chinese cooperatives develop sustainably given that the pursuit of potential policy benefits has been the important motivation for their formation?

Our research has partially answered the question from both members' and cooperative perspectives. Though some scholars hold negative views about the future of Chinese cooperatives (Yuan, 2013; Deng and Wang, 2014), members' trust in their cooperative leaders and Chinese community environment in the village are positive in forming member commitment to some extent. To improve member commitment to cooperatives, especially affective commitment and normative commitment, trust is the key factor. Besides improving trust among members, chairpersons and other members in management positions need to enhance management skills and abilities to earn more trust from other members. Meanwhile, cooperatives can improve the service quality to increase members' satisfaction with cooperatives' service and group cohesion thus to improve member commitment. Additionally, cooperatives should stick to democratic principles and involve members in decision-making processes, through which to improve members' affective commitment. Finally, cooperatives should be aware of negative effect of growth and expansion. Enlarging the cooperative scale can have negative effect on member' continuance commitment.

Despite these contributions, we acknowledge the limitations of this research, which is due to methodological and data constraints. Because member commitment is measured by Likert scales from 1 to 5, Generalized Structural Equation Model (GSEM) is thus more appropriate than standard linear Structural Equation Modeling (SEM) for our case given its metrics for fitting not just linear but also generalized linear models. However, GSEM is a newly developed modelling method. The post-estimation tests, especially the test for the goodness fit of models are not complete in statistical software, e.g. STATA. We thus choose SEM instead of GSEM because of this constraint. The other limitation refers to the data about the measurement of latent constructs. The data used is based on members' self-report. Although we have taken various precautions to test the reliability and discriminant validity of 
constructs, the results must still be interpreted with caution, for example, we have tried to avoid the use of words about causal relationship in the antecedent analysis. 


\section{References}

Agarwal, B., 2001. Participatory exclusions, community forestry, and gender: An analysis for South Asia and a conceptual framework, World Development. 29, 1623-1648.

Allen, N. J., Meyer, J. P., 1990. The measurement and antecedents of affective, continuance and normative commitment to the organization, Journal of Occupational Psychology. 63, 1-18.

Avolio, B. J., Zhu, W., Koh, W., Bhatia, P., 2004. Transformational leadership and organizational commitment: Mediating role of psychological empowerment and moderating role of structural distance, Journal of Organizational Behavior. 25, 951-968.

Bagozzi, R. P., Dholakia, U. M., 2002. Intentional social action in virtual communities, Journal of Interactive Marketing. 16, 2-21.

Barling, J., Christie, A., Hoption, C., 2010. Leadership, in S. Zedeck ed., Handbook of Industrial and Organizational Psychology. American Psychological Association, Washington, D.C.

Barraud-Didier, V., Henninger, M.-C., El Akremi, A., 2012. The relationship between members' trust and participation in the governance of cooperatives: the role of organizational commitment, International Food and Agribusiness Management Review. 15, 1-24.

Baumeister, R. F., Leary, M. R., 1995. The need to belong: desire for interpersonal attachments as a fundamental human motivation, Psychological Bulletin. 117, 497.

Bhuyan, S., 2007. The "people" factor in cooperatives: An analysis of members' attitudes and behavior, Canadian Journal of Agricultural Economics/Revue canadienne d'agroeconomie. 55, 275-298.

Bijman, J., Hanisch, M., Sangen, G., 2014. Shifting control? The changes of internal governance in agricultural cooperatives in the EU, Annals of Public and Cooperative Economics. 85, 641-661.

Bijman, J., Verhees, F., 2011. Member or customer? Farmer commitment to supply cooperatives, International Conference on the Economics and Management of Networks (EMNet), Limassol, Cyprus.

Bollen, K. A., Long, J. S., 1992. Tests for structural equation models: introduction, Sociological Methods \& Research. 21, 123-131.

Bowles, S., Gintis, H., 2002. Social Capital and Community Governance, Economic Journal. 112, 419-436.

Carter, I., 2013. Human behavior in the social environment: A social system approach. AldineTransaction, USA.

Cechin, A., Bijman, J., Pascucci, S., Omta, O., 2013. Decomposing the Member Relationship in Agricultural Cooperatives: Implications for Commitment, Agribusiness. 29, 39-61.

Chin, W. W., 1998. Issues and opinions on SEM, Management Information Systems Quarterly. 22, vii-xvi.

Cook, M. L., 1995. The future of US agricultural cooperatives: A neo-institutional approach, American Journal of Agricultural Economics. 77, 1153-1159.

Deng, H., Huang, J., Xu, Z., Rozelle, S., 2010. Policy support and emerging farmer professional cooperatives in rural China, China Economic Review. 21, 495-507.

Deng, H., Wang, W., 2014. The nature of cooperatives and testing in reality - is there real farmer cooperatives in China, China Rural Economy, 15-26. (in Chinese)

Dholakia, U. M., Bagozzi, R. P., Pearo, L. K., 2004. A social influence model of consumer participation in network- and small-group-based virtual communities, International Journal of Research in Marketing. 21, 241-263.

Dunn, J. R., 1988. Basic cooperative principles and their relationship to selected practices, Journal of Agricultural Cooperation. 3, 83-93.

Fornell, C., Larcker, D. F., 1981. Evaluating structural equation models with unobservable variables and measurement error, Journal of marketing research, 39-50.

Fulton, M., 1999. Cooperatives and Member Commitment, Finnish Journal of Business Economics, 418-437.

Fulton, M., Giannakas, K., 2001. Organizational commitment in a mixed oligopoly: Agricultural cooperatives and investor-owned firms, American Journal of Agricultural Economics. 83, 1258-1265.

Hair, J. F., Black, W. C., Babin, B. J., Anderson, R. E., 2010. Multivariate data analysis, Seventh Edition. Prentice Hall, Englewood Cliffs, NJ.

Hofstede, G., 2001. Culture's Consequences: Comparing Values, Behaviors, Institutions and Organizations Across Nations. SAGE, Thousand Oaks, CA.

Hulland, J., 1999. Use of partial least squares (PLS) in strategic management research: A review of four recent studies, Strategic management journal, 195-204.

Jiang, L., Probst, T. M., 2016. The moderating effect of trust in management on consequences of job insecurity, Economic and Industrial Democracy, 0143831X16652945.

Jiménez, M. C. R., Martí, E. G., Ortiz, M. J. H., 2010. Member commitment in olive oil co-operatives: Cause and consequences, Journal of Co-operative Studies. 43, 24-35.

Jones, G. R., 2013. Organizational Theory, Design, and Change Pearson/Prentice Hall Company, Boston, MA.

Kandori, M., 1992. Social norms and community enforcement, The Review of Economic Studies. 59, 63-80. 
Klein, H. J., Molloy, J. C., Cooper, J. T., 2009. Conceptual foundations: Construct definitions and theoretical representations of workplace commitments, Commitment in organizations: Accumulated wisdom and new directions. 1, 3-36.

Kollock, P., 1994. The emergence of exchange structures: An experimental dtudy of uncertainty, commitment, and trust, American Journal of Sociology. 100, 313-345.

Kramer, R. M., 1999. Trust and distrust in organizations: Emerging perspectives, enduring questions, Annual Review of Psychology. 50, 569-598.

Laschinger, H. K. S., Finegan, J., Shamian, J., Casier, S., 2000. Organizational trust and empowerment in restructured healthcare settings: effects on staff nurse commitment, Journal of Nursing Administration. 30, 413-425.

Latane, B., 1981. The psychology of social impact, American psychologist. 36, 343-365.

Li, Y., Sun, J.-M., 2015. Traditional Chinese leadership and employee voice behavior: A cross-level examination, The Leadership Quarterly. 26, 172-189.

Liang, Q., Hendrikse, G., 2013. Core and common members in the genesis of farmer cooperatives in China, Managerial and Decision Economics. 34, 244-257.

Mayer, R. C., Gavin, M. B., 2005. Trust in management and performance: Who minds the shop while the employees watch the boss?, Academy of management journal. 48, 874-888.

Meyer, J. P., Allen, N. J., 1991. A three-component conceptualization of organizational commitment, Human resource management review. 1, 61-89.

Meyer, J. P., Stanley, D. J., Herscovitch, L., Topolnytsky, L., 2002. Affective, continuance, and normative commitment to the organization: A meta-analysis of antecedents, correlates, and consequences, Journal of vocational behavior. 61, 20-52.

Morris, J. H., Steers, R. M., 1980. Structural influences on organizational commitment, Journal of Vocational Behavior. 17, 50-57.

Mowday, R. T., Steers, R. M., Porter, L. W., 1979. The measurement of organizational commitment, Journal of vocational behavior. 14, 224-247.

Nilsson, J., Kihlén, A., Norell, L., 2009. Are traditional cooperatives an endangered species? About shrinking satisfaction, involvement and trust, International Food and Agribusiness Management Review. 12, 103123.

Oetzel, J. G., Ting-Toomey, S., 2003. Face concerns in interpersonal conflict: A cross-cultural empirical test of the face negotiation theory, Communication research. 30, 599-624.

Ole Borgen, S., 2001. Identification as a trust-generating mechanism in cooperatives, Annals of Public and Cooperative Economics. 72, 209-228.

Osterberg, P., Nilsson, J., 2009. Members' Perception of Their Participation in the Governance of Cooperatives: The Key to Trust and Commitment in Agricultural Cooperatives, Agribusiness. 25, 181-197.

Ostrom, E., 2000. Collective action and the evolution of social norms, Journal of Economic Perspectives. 14, 137-158.

Paunova, M., 2015. The emergence of individual and collective leadership in task groups: A matter of achievement and ascription, The Leadership Quarterly. 26, 935-957.

Qi, X., 2013. Guanxi, social capital theory and beyond: toward a globalized social science, The British journal of sociology. 64, 308-324.

Robinson, S. L., 1996. Trust and breach of the psychological contract, Administrative science quarterly, 574599.

Salancik, G. R., Pfeffer, J., 1978. A social information processing approach to job attitudes and task design, Administrative Science Quarterly, 224-253.

Schwartz, H., Davis, S. M., 1981. Matching corporate culture and business strategy, Organizational Dynamics. 10, 30-48.

Sholihin, M., Pike, R., Mangena, M., Li, J., 2011. Goal-setting participation and goal commitment: Examining the mediating roles of procedural fairness and interpersonal trust in a UK financial services organisation, The British Accounting Review. 43, 135-146.

Sloot, N., 2016. Commitment and its determinants: Insights from cooperative and marketing literature and an evaluation of the NCR questionnaire, Management Studies Group. Wageningen University\&Research, Waganingen, NL.

Solinger, O. N., Van Olffen, W., Roe, R. A., 2008. Beyond the three-component model of organizational commitment, Journal of Applied Psychology. 93, 70.

Stanley, L., Vandenberghe, C., Vandenberg, R., Bentein, K., 2013. Commitment profiles and employee turnover, Journal of Vocational Behavior. 82, 176-187.

Tadesse, G., Kassie, G. T., 2017. Measuring trust and commitment in collective actions Evidence from farmers' marketing organizations in rural Ethiopia, International Journal of Social Economics. 44, 980-996. 
Tsai, W., Ghoshal, S., 1998. Social capital and value creation: The role of intrafirm networks, Academy of Management Journal. 41, 464-476.

Tsui, A. S., Farh, J.-L. L., 1997. Where guanxi matters: Relational demography and guanxi in the Chinese context, Work and Occupations. 24, 56-79.

White, S. C., 1996. Depoliticising development: the uses and abuses of participation, Development in Practice. 6, 6-15.

Wiener, Y., 1982. Commitment in organizations: A normative view, Academy of Management Review. 7, 418428.

Yilmaz, C., Hunt, S. D., 2001. Salesperson cooperation: The influence of relational, task, organizational, and personal factors, Journal of the Academy of Marketing Science. 29, 335-357.

Yuan, P., 2013. Study on the mutation of Chinese characteristic cooperatives, China Rural Survey. 3, 40-46.(in Chinese) 



\section{Synthesis}

This chapter summarizes and reflects on the thesis as a whole. Sections 6.1 and 6.2 present the research objectives and the four research questions addressed in Ch. $2-5$ as well as the answers to those questions. This is followed by further conclusions, drawn from the study as a whole (Section 6.3), and a discussion of the main limitations of the thesis. The chapter ends with a critical discussion about the research project and a reflection on the Chinese policy of promoting cooperatives.

\subsection{Introduction}

The food market in China is experiencing structural change characterized by an increasing demand for better quality food and for food produced according to stricter safety standards (Narrod, et al., 2009). Such changes in food markets call for better coordination of the sequential activities in the value chain (Fritz and Schiefer, 2008).

The implementation of the Household Responsibility System since the early1980s led to land fragmentation and the prevalence of small farms. Facing changes in food markets, livelihoods of small farmers become increasingly vulnerable due to asymmetric information and smallscaled production. These constraints cause high cost of complying with stricter production standards and weak bargaining positions when dealing with other entities in the food chain. Cooperatives are considered to be an institutional vehicle that can better link smallholder farmers to the market and help them obtain the benefits from modern food chains (Ito, et al., 2012, Royer, et al., 2016).

Due to the national government's supportive policies, the number of cooperatives has been increasing rapidly since 2007 , and $47 \%$ of Chinese farm households now participate in at least one cooperative. However, whether these cooperatives really work in the interest of their farmer-members is still an open question. Some scholars have pointed out that Chinese cooperatives deviate from the traditional member-ownership and member-benefit principles and that some cooperatives have rent seeking problems such that small-scale farmer-members are getting exploited by large-scale farmer-members.

This thesis assesses the impact of cooperatives on Chinese smallholder farmers. This assessment is done in four steps: (1) a description of the current development status of 
Chinese agricultural cooperatives; (2) an exploration of the economic and non-economic factors affecting farmers' choice of participating in cooperatives; (3) an evaluation of the impact of cooperatives on farmers' choice of marketing channels and production behaviours; and (4) a discussion of the factors that affect the durability of agricultural cooperatives in China. The results and conclusions from this study provide insights into ways in which the government can enhance its support for cooperatives to help smallholder farmers cope with the challenges of China's modern food markets.

\subsection{Research objective and research questions}

The overall objective of this thesis is to examine the impact of cooperatives on smallholder farmers. This objective is met by providing answers to four specific research questions.

The first research question - "What are the developments and characteristics of farmers' cooperatives in China?" - is answered based on an extensive review of both Chinese and English language literature on agricultural cooperatives. The main characteristics of Chinese cooperatives can be summarized as follow: (1) the establishment is often the result of the combined efforts of entrepreneurial farmers recognizing economic opportunities in changing market conditions and governmental policy of promoting farmers' cooperatives; (2) cooperative equity mainly comes from a small group of members, the so-called core members, rather than from all the members of the cooperative; (3) decision rights are usually held by the core members; (4) proportional voting rights is legitimate in Chinese farmers' cooperatives rather than the strict one-member one-vote rule; (5) membership heterogeneity is large; (6) the Chinese government has been crucial for the genesis of cooperatives after 2007, and government support has been instrumental in the establishment of a large number of new cooperatives. Unfortunately, abundant government support has also lead to the establishment of many so-called 'fake' cooperatives (Pan, 2011, Deng and Wang, 2014).

To answer research questions 2, 3 and 4, empirical analyses have been carried out based on data collected from a field survey among apples farmers in Shaanxi and Shandong provinces. Apples are the fruit with the largest plantation acreage in China. Profits from apples are the main income source for the farmers in the main producing regions. Our survey data show that the characteristics of the apple cooperatives are generally in line with the key characteristics summarized in Chapter 2. Specifically, more than $40 \%$ of the 63 surveyed cooperatives were initiated by or had village leaders and other government organizations involved in the 
establishment. Around $90 \%$ of the cooperatives received or had received concrete policy support (mainly financial support and subsidies from local governments) after their establishment. In all of these cooperatives core members and common members can be distinguished, with core members usually having additional voting rights due to their large equity shares or trading volumes with the cooperatives. It may therefore be assumed that the insights obtained for apple farmers and their cooperatives have a high relevance for smallholder farmers and cooperatives in general in China.

The second research question - "What are the effects of cooperative membership and other factors on farmers' choice of marketing channels?" - is answered on the basis of transaction cost economics theory by employing endogenous switching Probit models, which take into account the potential endogeneity of cooperative membership decisions. The estimation results show that cooperative membership has a significantly positive effect on the choice of wholesalers as marketing channel, along with a negative effect on choosing small dealers and an insignificant effect on choosing cooperatives as marketing channel.

The third research question - "What is the effect of cooperative membership on smallholder farmers' yields and profits and how are the effects produced?" - is explored by applying endogenous treatment regression models (ETRM) to estimate the effects of cooperative membership on yields and profits per unit area for members and for non-members. The pathways through which the different effects for the two groups are produced are examined by ETRM. It is found that, although cooperative membership has significantly positive treatment effects on apple yields, it has no significant treatment effect on profits. This finding can be explained by differences in effectiveness of input use by member farmers and nonmember farmers mainly due to the trainings provided by the cooperatives.

The fourth research question - "What are the factors that affect member commitment to cooperatives in China?" - is analysed by estimating structural equation models, which take both members' and cooperatives' characteristics into account. The results show that both trust and social pressure are positively associated with the three components of member commitment - affective commitment, continuance commitment and normative commitment. Furthermore, member participation plays a partially mediating role between trust and affective member commitment. 


\subsection{Additional conclusions}

Four additional conclusions can be drawn from the study as a whole. They are discussed in the following sections.

\subsubsection{Insignificant impact of government support on farmers' participation in cooperatives}

The Chinese government has been crucial in the genesis of cooperatives in China.

Particularly since 2007, government support has been an important motivation for the foundation of cooperatives (Deng, et al., 2010). We thus hypothesize that cooperative policies affect farmers' individual decisions about participating in cooperatives. Two dummy variables have been used to sketch the policy settings: whether the cooperative was initiated by village cadres or by another government organisation in Chapter 3 and whether the performance of local cooperatives is one criteria for evaluating the performance of village cadres in Chapter 4. We found that neither of the policy variables has a statistically significant impact on farmers' decisions to participate in cooperatives. Comparing the results in Chapter 2 with those in Chapters 3 and 4, we can conclude that even though Chinese government policy has played a crucial role in the establishment of cooperatives, the policy does not significantly affect farmers' individual decisions to participate in a cooperative. This conclusion reflects the voluntary participation principle for cooperatives.

\subsubsection{Cooperative services make the difference}

Not only can cooperatives enable farmers to bargain collectively with buyers of farm products (Bijman and Iliopoulos, 2014) and facilitate farmers' access to markets (Markelova, et al., 2009), they also offer specific trainings, technical assistance and other extension services to members. Research shows that cooperatives generally increase the probability of adopting synthetic fertilizers and other high-yielding technologies (Abebaw and Haile, 2013, Verhofstadt and Maertens, 2014). Therefore, we hypothesize that these cooperative services not only improve members' access to output market, but also change members' production practices. The empirical analyses for apples farmers in Chapter 3 and Chapter 4 generally confirm the hypotheses. The effects of cooperative membership on farmers' choice of marketing channels (positive for the wholesaler channel, negative for the small dealers channel, and insignificant for the cooperatives channel) can be explained by the cooperatives' small market share at present and the marketing information services and marketing coordination activities provided to the members. Even if cooperatives do not buy their 
members' apples, most of them collect marketing information, introduce wholesalers to members and help coordinate sales transactions for members.

We found that the effectiveness of input use is different between member and non-member groups. Although cooperative membership has significantly positive treatment effects on apple yields, it has no significant treatment effect on profits. This finding differs from the positive effects of cooperative membership on farmers' welfare found in most studies so far (e.g. Ma and Abdulai, 2016). The different result for apple yields and profits can be due to production trainings and other services provided by the cooperative or by differences between members and non-members in the efficacy of inputs use. Members receiving training have higher yields than non-members. However, members tend to spend more on purchasing inputs than non-members. Given the high wage rates and high prices of non-labour inputs in China during the survey year, the gains from the extra yields do not cover the extra costs. Therefore, even though members have a higher average apple yield than non-members, their profits from apple production per unit area are not significantly different from those of their counterparts.

\subsubsection{Early stage of development}

Chinese cooperatives have been developing quickly both in number and scope, especially since the first farmers' cooperative law was implemented in 2007. Compared with most cooperatives in Western Europe with more than a century of cooperative history, Chinese cooperatives are still young and in the phase of economic justification or organizational design according to the cooperative life cycle framework (Cook and Burress, 2009). Chinese cooperatives differ from their counterparts in Western Europe by the top-down initiation of Chinese cooperatives, their voting rights proportional to equity holding and to the volume of transactions with the cooperative, and by the existence of core members. The small market shares of cooperatives and the insignificant effect of cooperative membership on farmers' selling products to cooperatives and on farmers' profits suggest that cooperatives in China are still in an early stage of development.

\subsubsection{Important role of cooperative leaders in cooperative development}

The analysis of the genesis of Chinese cooperatives shows that the convergence of interests of specific entrepreneurs and local political leaders has been a major factor in the initiation of cooperatives. The involved entrepreneurs usually became cooperative leaders once the cooperative has been established. The success of cooperatives crucially depends on the 
functioning of its leaders, as we found in Chapter 5 that members' trust in cooperative leaders positively affects member commitment (including affective commitment, continuance commitment and normative commitment). Because member commitment concerns cooperatives' viability and success, we can draw the conclusion that cooperative leaders play important roles not only in the initiation of cooperatives, but also in the sustainability of cooperatives in China.

\subsection{Research Method and its Limitations}

\subsubsection{Sample selection}

There are two reasons for choosing apple farmers and apple farmer cooperatives as the subjects of this study. The first reason for focusing on apples farmers and apple farmer cooperatives in China is that China is the world's leading producer of apples, producing roughly 55\% of the total apple output in 2015 (Frederick, et al., 2015). Apple is the fruit crop with the largest acreage and the highest production value in China, and has been the dominant income source of farmers in the two main apple production regions - the Bohai Gulf and the Loess Plateau (Hou and Liu, 2014). Apple is one of the most important fruits consumed in China. Therefore, I chose apple as an example of a horticultural crop with high-value added. An extensive field survey was carried out between January and March in 2015. Data about 700 apple farm households' production and marketing behaviours and perceptions about transactions were collected in Shaanxi Province located in the Loess Plateau and Shandong Province in Bohai Gulf areas.

The second reason is related to the constraints of organising field surveys in the countryside of China. A field survey of farmers needs the assistance from the local government. For example, the local Agricultural Bureau in a county usually has the latest information about the cooperatives in that county. The first step for selecting the targeted cooperatives is getting the name list and the latest contact information about the local cooperatives from the Bureau. Therefore, a connection with the Bureau is essential to carry about a survey. Our partner, Northwest Agriculture \& Forestry University, has been conducting research about the apple economy in China for more than 10 years and is familiar with the two research areas and has good contacts with the local governments. These advantages made it relatively convenient for us to conduct field surveys in Shaanxi and Shandong provinces. 


\subsubsection{Data}

Like in most empirical research, some important data limitations exist in the empirical analyses. First, the data used in the analyses are collected by face-to-face interviews with apple farmers. The data about the inputs used and the marketing details are partly based on farmers' written records. Farmers who did not record their production and marketing details answered the questions by memory recalls. This may have resulted in errors in data of inputs used and outputs marketing. The approaches used in this thesis assumed that these data errors can be considered as random disturbances. In addition, some variables have missing data. For instance, some of the interviewed farmers had not yet sold any apples of the 2014 harvest but still kept the apples in local cold storages during the survey. I thus excluded these farmers from our analysis in Chapter 3.

Second, all the empirical analyses in the thesis are based on cross-sectional data. In Chapter 4, I analysed the factors affecting farmers' yields and profits mainly from the input aspect, without including variables about the external market environment which may be different for different units of observations. Furthermore, the treatment effect of membership on the yield and profits per unit area is assessed by comparing member and non-member groups. If panel data were available, it would be possible to compare ex-ante and ex-post cooperative participation decisions among farmers while controlling for factors that remain constant over time. Thus the changes in farmers' participation decisions over time and their impacts on the yield and profits can be examined under the assumption that the market environment remained constant.

Due to data constraints, I have only explored the determinants of farmers' choice of marketing channels from the perspective of farmers in Chapter 3. If I had data about buyers and other parties in the value chain, especially information about the flexibility of each marketing channel, the services provided and the prices offered by different buyers, a richer insight into farmers' choices of marketing channels would have been gained. Given these data limitations, follow-up research should preferably focus on performing panel data analyses once suitable data sets for applying such methods become available, and on examining marketing from demand as well as supply perspectives.

\subsubsection{Research method}

In Chapter 2 we use a comparative literature review. By comparing six key aspects, the characteristics and development of Chinese farmer cooperatives have been compared with 
those of Western European cooperatives, and the underlying causes have been explored. However, due to the relatively young age of Chinese cooperatives and their small market shares at present, few scientific studies in Chinese or English about the role of cooperatives in value chains are available. In addition, there is hardly any literature on the relationship between members and their cooperatives in China while there is an extensive literature on the relationship between members and cooperatives in Western Europe. Particularly research on member commitment is missing for Chinese cooperatives. Therefore, I could not compare cooperatives in China with the Western European ones for these two important aspects. In the other parts of the thesis I used econometric methods. A potential disadvantage of applying econometric methods is that the estimation results may provide only partial answers to the research questions. Interpretations can be made only on the basis of the specific variables included in the models and the specific theories underlying the relationships for those variables. For example, in Chapter 3, when I examined determinants of farmers' choice of different marketing outlets and farmers' decisions of cooperative membership, I included variables about transaction specificities in the models. Psychological variables (such as farmers' perceptions about different marketing choices) that may also affect farmers' final choices were excluded because of the potential endogeneity of these perceptional variables. Furthermore, the difficulty in finding valid instruments for potentially endogeneous explanatory variables severely limits the extent to which econometric methods can be used for explaining reality.

Another methodological limitation of this thesis is the method applied in Chapter 5 to examine factors explaining member commitment. Since the dependent variables are measured by Likert scales, with answers ranging from 1 to 5, Generalized Structural Equation Model (GSEM) is more appropriate than standard linear Structural Equation Model (SEM). GSEM is an appropriate estimation method when dependent variables are ordinal, but unfortunately econometric software like STATA does not provide post-estimation tests for GSEM. For this reason, I chose to apply SEM in Chapter 5. With the technical development of GSEM, GSEM may be preferred in future research when the dependent variable is categorical or ordinal. 


\subsection{Reflections on Chinese cooperative policies}

To further develop modern agriculture and to tackle the problem of linking small farmers to modern agro-food markets, the Chinese government has been encouraging famers to participate in farmer cooperatives to realize economies of scale in marketing and at the same time support other new types of agricultural businesses (Hu, 2012). With the policy support, cooperatives have been developing quickly in number and business scope in the past decade. The implementation of the first cooperative law in 2007 and the revision at the end of 2017 show the importance of farmer cooperatives in Chinese agricultural policy.

In contrast with the rapid increase in the number of cooperatives, the market share of cooperatives is still low. Chinese cooperatives are still in the early stage of development. What role cooperatives will play in the changing agricultural markets and how they can provide benefits to both smallholder farmers and consumers in China are questions that need to be further explored. Answers to these two questions concern Chinese smallholder farmers' options in adapting to new high-value-added markets.

Policy support has been an important driver for the initiation of cooperatives in China. However, abundant interference from the government can have negative effects on cooperative development, and even contribute to the creation of fake cooperatives (Deng and Wang, 2014). The establishment of these cooperatives is mainly motivated by obtaining financial support from the government.

One of the most important elements of the 2017 revision of the farmers' cooperative law is the revoking of the cooperative's license when there is no business operation in two consecutive years. This revision can reduce the problem of fake cooperatives to some extent. Another revision is acknowledging the legal status of the cooperative union by the cooperative laws. A cooperative union is a cooperative of cooperatives, and carries out economic activities that require a scale that is beyond the scope of the individual membercooperatives.

The impact of policy support for farmers' cooperatives depends to a large extent on institutional reforms such as land tenure reforms. The recent land tenure reform of separating land ownership, land contracting right and land management right is expected to promote further development of land rental markets, and thereby contributes to larger operation scales of cooperatives by integrating the previously fragmented land. Hence, the recent land tenure 
reform and policy promoting the development of agricultural cooperatives seem to mutually reinforce each other.

Instability of policies can be an important factor in farmers' decisions on cooperative membership and involvement in high-value chains. Policy promoting farmers' cooperatives and related policies should preferably not change too often and too rapidly, in order to decrease farmers' perception of policy uncertainty. If not, farmers' motivation to participate and invest in the cooperatives is likely to be low.

As this thesis shows, Chinese cooperatives are currently facing important problems inherent to their characteristics and development paths. But it also shows that members' trust in the cooperative leadership and the Chinese community environment in villages positively affect member commitment. Being members of the cooperatives examined in this study does not significantly affect the selling of output through the cooperative marketing channels, nor does it affect farmers' profits significantly. Potentially, Chinese cooperatives can be helpful for smallholders to improve their economic situation by adapting to the changes in the food market and strengthening their market position. Other institutional reforms in rural areas such as further land tenure reforms may be needed to realize this potential. 


\section{References}

Abebaw, D., Haile, M. G., 2013. The impact of cooperatives on agricultural technology adoption: Empirical evidence from Ethiopia, Food Policy. 38, 82-91.

Bijman, J., Iliopoulos, C., 2014. Farmers' cooperatives in the EU: Policies, strategies, and organization, Annals of Public and Cooperative Economics. 85, 497-508.

Cook, M. L., Burress, M. J., 2009. A cooperative life cycle framework, International Conference 'Rural Cooperation in the 21st Century: Lessons from the Past, Pathways to the Future', Hebrew University of Jerusalem, Rehovot, Israel.

Deng, H., Huang, J., Xu, Z., Rozelle, S., 2010. Policy support and emerging farmer professional cooperatives in rural China, China Economic Review. 21, 495-507.

Deng, H., Wang, W., 2014. The nature of cooperatives and testing in reality - is there real farmer cooperatives in China, China Rural Economy, 15-26.

Frederick, C., Liu, M., Wu, B., 2015. 2015 Fresh Deciduous Fruit Annual for China. GAIN Report, USDA, Washington, D.C. Fritz, M., Schiefer, G., 2008. Food chain management for sustainable food system development: a European research agenda, Agribusiness. 24, 440-452.

Hou, J., Liu, J., 2014. Effects of transaction costs on market behaviours of farmer households, Journal of Agrotechnical Economics, 25-36.

$\mathrm{Hu}$, J., 2012. Firmly march on the path of socialism with Chinese characteristics and strive to complete the building of a moderately prosperous society in all respects, People Daily. Xinhua Agency, Beijing.

Ito, J., Bao, Z. S., Su, Q., 2012. Distributional effects of agricultural cooperatives in China: Exclusion of smallholders and potential gains on participation, Food Policy. 37, 700-709.

Ma, W., Abdulai, A., 2016. Does cooperative membership improve household welfare? Evidence from apple farmers in China, Food Policy. 58, 94-102.

Markelova, H., Meinzen-Dick, R., Hellin, J., Dohrn, S., 2009. Collective action for smallholder market access, Food policy. 34, 1-7.

Narrod, C., Roy, D., Okello, J., Avendaño, B., Rich, K., Thorat, A., 2009. Public-private partnerships and collective action in high value fruit and vegetable supply chains, Food Policy. 34, 8-15.

Pan, J., 2011. Specialized Farmers' Cooperatives in China: The Interpretation of the Data of their Development, China Rural Survey. 6, 2-11.(in Chinese)

Royer, A., Bijman, J., Bitzer, V., 2016. Linking smallholder farmers to high quality food chains: Appraising institutional arrangements, in J. Bijman and V. Bitzer eds., Quality and innovation in food chains: Lessons and insights from Africa. Wageningen Academic Publishers, Wageningen, NL.

Verhofstadt, E., Maertens, M., 2014. Can Agricultural Cooperatives Reduce Poverty? Heterogeneous Impact of Cooperative Membership on Farmers' Welfare in Rwanda, Applied Economic Perspectives and Policy, $1-21$. 



\section{Summary}

China is facing two major challenges to further develop modern agriculture. The first challenge comes from the land fragmentation and small-scale farms. The second challenge is the adaptation of smallholder farmers to recent changes in the agro-food market, particularly the growing demand for safer and better quality food, technical developments in controlling food safety, and the rise of supermarkets. These recent changes require farmers to follow stricter and safer production standards and better sequential coordination work in the value chain. High compliance costs and the small production and transaction scales of smallholders can exclude them from the value chains. Well-functioning cooperatives enable smallholder farmers to unite, improve their bargaining power, and mitigate market failures.

The Chinese government has actively promoted the development of farmers' cooperatives since 2007, when the first law on farmers' cooperatives was promulgated. Over $47 \%$ of Chinese farm households have participated in at least one cooperative by 2017 and the number is still growing. In contrast to the rapid growth in the number of cooperatives, their market share has remained low. Rent-seeking by a small group of cooperative members and other problems preclude a rapid expansion of the market share.

The general objective of this research is to obtain a better understanding of the characteristics and the development path of Chinese cooperatives and the effect of cooperatives on farmers' marketing and production behaviours. The objective is achieved by answering four research questions in four separate chapters.

In Chapter 2 the development and characteristics of farmers' cooperatives in China, especially since the promulgation of the first law on farmers' cooperatives in 2007, is analysed. Views diverge among scholars on the effectiveness of cooperatives, which can be partly attributed to lacking understanding about the key characteristics of Chinese cooperatives. I compare Chinese cooperatives with the ones in Western Europe in six aspects, based on an extensive literature review of studies prepared both in English (from the 1940s to 2016) and in Chinese (mainly from 2006 to 2016). Chinese cooperatives distinguish themselves from their counterparts in Western Europe mainly from the following aspects: (1) The establishment of most Chinese cooperatives is the result of combined efforts of policy advocacy of developing cooperatives and the need of entrepreneurial farmers to cope with 
structural changes in the agro-food market. (2) Cooperative equity comes from a small group of members, called core members. (3) Additional voting rights are legitimate and are granted to members who hold big shares of a cooperative and have big transaction volumes with a cooperative. (4) Much member heterogeneity exists in Chinese cooperatives, especially between core members and common members. (5) Decision rights are held by core members in Chinese cooperatives. (6) Governmental supports can be instrumental to cooperative development, but abundant government interference is responsible for the existence of fake cooperatives which seek financial supports from the government but operate no business.

Chapter 3 examines the effect of cooperative membership and other factors on farmers' choice of marketing channels. A conceptual framework based on transaction cost economics, considering not only production-specific assets but also institutional environment and transaction uncertainties, is developed. Field survey data about 625 apple farmers are used for the analysis. Given the potential endogeneity of membership in estimating farmers' choice of marketing channels, endogenous switch probit models are applied. The results show that cooperative membership has a significantly positive effect on the choice of wholesalers as marketing channels, along with a negative effect on choosing small dealers and an insignificant effect on choosing cooperatives. Cooperative services, especially marketing information services, and other marketing arrangement activities lead to the varying effects of membership on farmers' choice regarding different marketing channels.

The effect of cooperative membership on smallholder farmers' yields and profits is examined in Chapter 4. A novel theoretical framework is built that shows the different mechanisms through which cooperatives membership, particularly the specific trainings, technical assistance and other extension services offered by cooperatives, affect farmers' yield and profits from crop production. Given that cooperative membership is potentially endogenous to farmers' yields and profits, endogenous treatment regression models (ETRM) are employed to assess the average treatment effects of cooperative membership on yields and profits per unit area. It is found that cooperative membership has a significantly positive effect on yields, but no significant effect on profits per unit area. Two pathways explain these different effects. First, cooperative services change members' production practices, especially the use of inputs that lead to higher land productivity. Second, members on average spend more on fertilizers and use more hired labour than non-members, which results in higher production costs. The extra revenues generated by the increased yields roughly compensate the extra production costs of the members. 
Chapter 5 deals with the antecedents of member commitment to cooperatives in China. Based on the three-component commitment model, I investigate the antecedents of member commitment from both members' and cooperatives' perspectives. Using a sample of 391 farmer cooperative members in China, this chapter focuses on whether trust in the cooperative leadership and social pressure affect cooperative member commitment and if so, what is the pathway how these two antecedents produce their effects on member commitment. Structural equation models are estimated from the data set of cooperative members. The estimation results show that both trust and social pressure are positively associated with affective commitment, continuance commitment and normative commitment in a direct way. Furthermore, trust positively influences affective member commitment indirectly via the partial mediator of member participation. These findings offer empirical evidence on the importance of trust in the cooperative chairpersons' leadership and social pressure in generating cooperative member commitment in China.

The research reported in the thesis contributes to the literature in three ways. First, it provides a systematic analysis of the typical characteristics of Chinese cooperatives and their development paths in six key aspects. Second, it uses transaction costs economics as the theoretical framework for the analysis of factors affecting farmers' marketing and production decisions. Third, it integrates psychological factors and cultural factors in the empirical analysis of member commitment to cooperatives. 


\section{Acknowledgement}

Pursuing a $\mathrm{PhD}$ is one of the best things that I have done in the past thirty years. During the years, I have the luck to be guided and accompanied by a group of wonderful people. The help from these people is gratefully acknowledged here.

I owe earnest thanks to my great supervision team - Wim Heijman, Nico Heerink and Jos Bijman for their tremendous efforts to keep me on track and the thesis structured and organized. With their professional guidance and supports, I have been learning how to be an independent researcher gradually. Wim has inspired me both in the work and life. His broad research vision and knowledge stimulates me to keep both eyes and the heart open beyond my own research field and to remain curious and enthusiastic about knowledge and the world. His tens of years of sport habit has persuaded me that persistence is the key to keep charming. Nico has personally shown me how to be a scholar in the past years. I have benefited a lot from both his attitude to academics and his critical but insightful comments. Being serious and precise is necessary to be a good researcher. Jos has taught me how to make successful communications, either in person or via papers. Even though I still have long way to go before I become a good scientific writer, I am fortunate to have his guidance in my way. Additionally, special thanks go to Koos Gardebroek for his co-authorship and contributions to Chapter 3 of this thesis. I also feel grateful with the great help and support from Professor Xia (Xianli), Professor Huo (Xuexi) and Dr. Liu (Jundi) during the field survey in 2015. Thanks also go to Professor Jia (Xiangping), Jiajia, Xingdong, Xu Han, Liming, Lianhua and many other master students in Northwest A\&F University and the farmers who participated in the data collection.

Many thanks go to my other lovely colleagues in Agricultural Economics and Rural Policy Group: Justus, Jack, Liesbeth, Roel, Dusan, Rico, Shanshan, Evert, Hoyga, Thomas, Mohammed, Dadan, Eko, Praxedis, Issac, Adugna, Yan, Muyinatu, Undrakh, Bek, Choka and Min. People gather and then leave the group, but the memories always stay. Particularly, some colleagues have become close friends, Anouschka, Qianqian, Anastasia and Karen. Hundreds of thanks go to our awesome supporting team, Dineke, Betty, Gré, and of course Karen, who have helped me so much that my life and work are easier here.

I am lucky to be surrounded by a bunch of like-minded friends in the past years. Keyang, Lingtong, Chuchu, Xiaomei and Jorijn are the ones who have shared most of my emotions. 
Zihan, Huimin, Guangcheng, Changkun, Minjie, Yu Hong, Chen Qian, Kai Wang and Fan Li are the ones who distract me from the tiredness and have had a lot of lunches, dinners and fun together. Hongming, Miao Yu, Yueling, Fanrong, Yixin, Hans, Ellen and my other corridor mates have brought me much laughter. I cherry the friendship for the rest of my life. Thanks also go to Mr. Marcel Wubs, who has made TRX my favourite gym class and I thus can keep healthy and energetic for the majority of the time. Thanks to all for making my life beautiful. I would like to thank all my families for their endless love and support all the time. I owe everything to my beloved parents, especially my mother. Thanks for her love and sacrifice. Finally, I can tell my father proudly that Baba, I have made it!

Jinghui Hao

June, 2018 


\section{Biography}

Jinghui Hao was born on $18^{\text {th }}$ October, 1987 in Henan, China. She started to study International Economics and Trade in Northwest A\&F University in 2006 and obtained Bachelor of Economics in 2010. In 2013, she completed her master's degree in Regional Economics from the same university.

In September 2013, Jinghui started her PhD studies at the Agricultural Economics and Rural Policy Group (AEP). As part of her $\mathrm{PhD}$ research, she has presented papers at various scientific conferences (e.g. EAAE) and followed various course organised by Wageningen School of Social Sciences (WASS). Her research interest includes cooperatives, value chain research, sustainable development and institutional economics. 
Jinghui Hao

Wageningen School of Social Sciences (WASS)

Completed Training and Supervision Plan

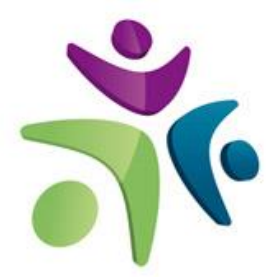

Wageningen School

of Social Sciences

\begin{tabular}{llll}
\hline Name of the learning activity & Department/Institute & Year & ECTS*
\end{tabular}

A) Project related competences

Institutional Economics and Economic

WUR

$2014 \quad 6$

Organizations, AEP20806

Advanced Microeconomics, ECH51806

WUR

$2014 \quad 6$

Advanced Econometrics, YSS34306

WUR

20156

B) General research related competences

Introduction course

WASS

$2013 \quad 1$

Research Methodology: From Topic to

WASS

$2014 \quad 4$

Proposal

Proposal Writing

WUR

$2014 \quad 6$

Empirical applications of economic organization and institutions in agri-food value chains

Summer school, University of

$2014 \quad 1.5$

Primorska, Faculty of

Management Koper, Slovenia

“Cooperative membership and farmers' choice

$9^{\text {th }}$ CAER-IFPRI Annual

2016

of marketing channels - Evidence from apple

Conference, Fuzhou, China

farmers in Shaanxi and Shandong Provinces,

China"

Multidisciplinary perspectives on quality

WASS

2016

improvement in value chains

Workshop "Big data analytics for agricultural economics research"

WASS

2016

0.3

"Cooperative membership and smallholders'

$15^{\text {th }}$ EAAE Congress, Parma,

$2017 \quad 1$

yields and profits - Evidence from apple

farmers in China"

Italy

Food value chain research: understanding inter- WASS Autumn school

2017

organizational relationships

\section{C) Career related competences/personal development}

Scientific Writing

WGS

2014

1.8

Techniques for Writing and Presenting a

WGS

2015

1.2

Scientific Paper

Information Literacy PhD including EndNote

WUR Library

$2014 \quad 0.6$ Introduction

Last stretch of the PhD Programme

WGS

2017

0

Total

38.9

*One credit according to ECTS is on average equivalent to 28 hours of study load 


\section{Colophon}

The research described in this thesis was financially supported by the Netherlands Foundation for Scientific Research (NWO) and the Chinese Academy of Social Sciences (CASS) through the Joint Scientific Thematic Research Programme (JSTP) (dossier number 833.13.003).

Financial supports from the China Scholarship Council (CSC) are gratefully acknowledged.

Cover design: Mingchao Hao

Printed by: Digiforce $\|$ ProefschriftMaken 